\title{
Palaeozoic to Early Jurassic history of the northwestern corner of Gondwana, and implications for the evolution of the Iapetus, Rheic and Pacific Oceans
}

\author{
Roelant van der Lelij ${ }^{1,2}$ Richard Spikings $^{1}$, Alexey Ulianov ${ }^{3}$, Massimo Chiaradia ${ }^{1}$ and Andrés \\ Mora $^{4}$
}

${ }^{1}$ Department of Earth and Environmental Sciences, University of Geneva, Rue des Maraichers 13, 1205 Geneva, Switzerland

${ }^{2}$ Present address: Geological Survey of Norway, PO Box 6315 Sluppen, 7491 Trondheim, Norway

${ }^{3}$ Institute of Mineralogy and Geochemistry, University of Lausanne, 1015 Lausanne, Switzerland

${ }^{4}$ Instituto Colombiano del Petróleo, Ecopetrol, Bucaramanga, Colombia

\begin{abstract}
The Palaeozoic to Mesozoic igneous and metamorphic basement rocks exposed in the Mérida Andes of Venezuela and the Santander Massif of Colombia are generally considered to define allochthonous terranes that accreted to the margin of Gondwana during the Ordovician and the Carboniferous. However, terrane sutures have not been identified and there are no published isotopic data that support the existence of separate crustal domains. A general paucity of geochronological data led to published tectonic reconstructions for the evolution of the northwestern corner of Gondwana that do not account for the magmatic and metamorphic histories of the basement rocks of the Mérida Andes and the Santander Massif. We present new zircon U-Pb (ICP-MS) data from 52 igneous and metamorphic rocks, which we combine with whole rock geochemical and $\mathrm{Pb}$ isotopic data to constrain the tectonic history of the Precambrian to Mesozoic basement of the Mérida Andes and the Santander Massif. These data show that the basement rocks of these massifs are autochthonous to Gondwana and share a similar tectono-magmatic history with the Gondwanan margin of Peru, Chile and Argentina, which evolved during the subduction of oceanic lithosphere of the Iapetus Ocean. The oldest Palaeozoic arc magmatism is recorded at 500 Ma, and was followed shortly by Barrovian metamorphism. Peak metamorphic conditions at upper amphibolite facies are recorded by anatexis at $\sim 477 \mathrm{Ma}$ and the intrusion of synkinematic granitoids until $\sim 42$ Ma. Subsequent retrogression resulted from localised back-arc or intra-arc extension at $\sim 453 \mathrm{Ma}$, when volcanic tuffs and interfingered sedimentary rocks were deposited over the amphibolite facies basement. Continental arc magmatism dwindled after $\sim 430 \mathrm{Ma}$ and terminated at $\sim 415 \mathrm{Ma}$, coevally with most of the western margin of Gondwana. After Pangaea amalgamation in the Late Carboniferous to Early Permian, a magmatic arc developed on its western margin at 294 Ma as a result of subduction of oceanic crust of the palaeo-Pacific ocean. Intermittent arc magmatism recorded between $\sim 294$ and $\sim 225$ Ma was followed by the onset of the Andean
\end{abstract}


subduction cycle at $213 \mathrm{Ma}$, in an extensional regime. Extension was accompanied by slab rollback which led to the migration of the arc axis into the Central Cordillera of Colombia in the Early Jurassic.

\section{Introduction}

The Andes of Venezuela and Colombia host exposures of Precambrian to Phanerozoic orogenic belts (Fig. 1), which record the tectonic history of northwestern Gondwana. We combine a large quantity of new data with pre-existing information to reconstruct the Palaeozoic history of northwest Gondwana. Most attempts to reconstruct the pre-Mesozoic tectonic history have focused on crustal fragments that separated during the disassembly of Pangaea, and now form large parts of Central America and Mexico. Recent studies of basement rocks in Mexico (e.g. Keppie et al., 2008, 2012; Vega-Granillo et al., 2009a and references therein) and Central America (e.g. Ratschbacher et al., 2009; Estrada-Carmona et al., 2012 and references therein) have contributed large amounts of new data and palaeogeographic models. These models assume that the basement rocks of Mexico were juxtaposed against northwestern Gondwana in the Early Palaeozoic, which is supported by sparse $\mathrm{Pb}$ isotopic data from the Garzón Massif and the Sierra Nevada de Santa Marta of Colombia (Fig. 1; e.g. Yañez et al., 1991; Ruiz et al., 1999) and faunal similarities between Early Palaeozoic sedimentary rocks exposed in Mexico and the Mérida Andes of Venezuela (e.g. Stewart et al., 1999). However, most models of the Palaeozoic evolution of the basement rocks exposed in the Northern Andes imply that they are allochthonous to northwestern Gondwana, and accreted during the Ordovician and the Carboniferous (e.g. Bellizzia and Pimentel, 1994; Aleman and Ramos, 2000; Ramos, 2009; Ramos, 2010). Therefore, it is unclear whether the basement of the Northern Andes or Central America can be used to constrain the Palaeozoic tectonic history of northwestern Gondwana, and for which time periods.

We present new in-situ zircon $\mathrm{U}-\mathrm{Pb}$ laser-ablation inductively coupled plasma-mass spectrometry (LA-ICP-MS) ages, whole rock geochemistry and $\mathrm{Pb}$ radiogenic isotope data from the basement of the Mérida Andes of Venezuela and the Santander Massif of Colombia. These data are used to (i) test the hypothesis that there are allochthonous terranes in the Northern Andes, which accreted in the Ordovician and the Carboniferous, (ii) determine the tectonic origin of basement rocks exposed in the Northern Andes, and use these to propose plate reconstructions for the evolution of the southern Iapetus and Rheic oceans, and (iii) investigate the possible connections between the basement sequences in northwestern South America and Mexico. 


\section{Geological Framework}

The present-day configuration of northwest South America is a consequence of interactions between the Caribbean, South American and Pacific Plates, which have formed the South Caribbean Plate Boundary Zone (Fig. 1). This broad, diffuse plate boundary hosts discrete tectonic blocks that have undergone alternating periods of dextral transtension and transpression since the Late Cretaceous (e.g. Colletta et al., 1997; van der Lelij et al., 2010; Bermúdez et al., 2011), generating regions of high topography isolated by rapidly subsiding basins. A prominent structural entity of the Southern Caribbean Plate Boundary Zone is the Maracaibo Triangular Block, which incorporates the Mérida Andes, the Santander Massif, the Sierra Nevada de Santa Marta and the basement of Lake Maracaibo (Fig. 1).

\subsection{The Mérida Andes}

\subsubsection{Igneous and Metamorphic basement}

The metamorphic basement of the Mérida Andes consists of Precambrian to Palaeozoic schists and gneisses, which are intruded by numerous granitoids (Fig. 2; Gonzales de Juana et al., 1980). These rocks are exposed within a transpressive orogen whose architecture is controlled by the active SWNE trending Boconó Fault (Colletta et al., 1997).

Metasedimentary schists, paragneisses and orthogneisses of the Iglesias Complex form the oldest rocks exposed in the Mérida Andes (Gonzales de Juana et al., 1980). The Iglesias Complex is subdivided by metamorphic facies into the greenschist facies Tostós and Bella Vista suites and the amphibolite facies Sierra Nevada Suite (Fig. 2; Odremán and Useche, 1997). Mapping has shown that the transition between the Tostós and Sierra Nevada suites is mainly conformable and follows metamorphic isograds (e.g. Case et al., 1990), which has led to the suggestion that the basement rocks in the Mérida Andes were metamorphosed simultaneously (Maréchal, 1983).

The Iglesias Complex is considered to be Proterozoic by most authors (e.g. Odremán and Useche, 1997; Aleman and Ramos, 2000), although there is a paucity of constraining data. Previous geochronological studies of the Iglesias Complex utilized the $\mathrm{K} / \mathrm{Ar}, \mathrm{Rb} / \mathrm{Sr}$ and multigrain $\mathrm{U}-\mathrm{Pb}$ methods (Fig. 3). Interpretations of those dates are complicated by inheritance of ancient radiogenic components and daughter isotope loss due to thermal overprinting or chemical alteration. The only Precambrian $\mathrm{U}-\mathrm{Pb}$ dates are upper intercepts of strongly discordant multigrain fractions of the Upper Caparo, Valera and Pedraza granitoids, which intrude the Iglesias Complex and yield ages of $615 \pm 40,593 \pm 16$ and 585 \pm 25 Ma, respectively (Fig. 3; Burkley, 1976). 
Most previous $\mathrm{U}-\mathrm{Pb}$ geochronology focused on undeformed igneous rocks, and the only reported U$\mathrm{Pb}$ data from the high grade Sierra Nevada Suite yielded an Ordovician age (Burkley, 1976). $\mathrm{Rb} / \mathrm{Sr}$ dates acquired from metasedimentary units suggest the rocks were metamorphosed in the Early and Late Palaeozoic (Fig. 3; e.g. Burkley, 1976; Kovach et al., 1977), and most K/Ar dates from the Iglesias Complex are Mesozoic.

Early Palaeozoic regional metamorphism of the Iglesias complex is inferred from the structural concordance of the metamorphic Sierra Nevada Suite with magmatic bodies that underwent synintrusive deformation (Schubert, 1969; Burkley, 1976; Kovach et al., 1977; Gonzales de Juana et al., 1980; Maréchal, 1983). The amphibolite facies metasedimentary rocks of the Sierra Nevada Suite record Barrovian metamorphism with clockwise pressure-temperature paths (Grauch, 1972). Granitic gneisses from the Sierra Nevada Suite near La Grita (Fig. 2) yield a 6 point Rb/Sr whole rock isochron age of $440 \pm 40 \mathrm{Ma}$ (Kovach et al., 1977), which was interpreted to estimate the timing of amphibolite facies metamorphism.

The Tostós Suite mainly consists of greenschist facies phyllites, schists, quartzites and slates, and may represent a lower grade equivalent of the Sierra Nevada Suite (Shagam and Grauch, 2006). It is intruded by the Pueblo Hondo granodiorite (08VDL04; Fig. 2) and several smaller bodies.

The Bella Vista Suite is a greenschist facies metasedimentary unit consisting of schists, slates and phyllites, and forms the basement of the Caparo Block (Fig. 2). No geochronological data have been obtained from this unit, but its deposition is loosely constrained to the Precambrian by the intrusive contact of several granitoids which yield strongly discordant Late Neoproterozoic to Palaeozoic U$\mathrm{Pb}$ ages (615 \pm 40 to $350 \pm 50 \mathrm{Ma}$; Fig. 3). The Bella Vista Suite is inferred to be unconformably overlain by Sandbian (Late Ordovician) sedimentary rocks of the Caparo Fm. (Gonzales de Juana et al., 1980), although field relationships between these units have not been observed.

\subsubsection{Palaeozoic to Jurassic sedimentary rocks}

The oldest, non-metamorphosed sedimentary rocks crop out in the Caparo Block (Fig. 2). The Caparo Fm. consists of micaceous fine to medium grained sandstones and siltstones, which yield fauna suggesting a Sandbian age (Odremán and Useche, 1997, Gutiérrez-Marco et al., 2011) of 461-456 Ma (Gradstein et al., 2012). Early Palaeozoic granitoids that are intrusive into the Caparo Fm. generated chiastolite bearing contact aureoles (Gonzales de Juana et al., 1980) suggesting 
shallow intrusion at less than $\sim 3.5$ kbar. A conglomerate containing clasts of basement rocks separates this unit from the overlying El Horno Fm., which consists of siltstones and lithic sandstones yielding brachiopods of Early Llandovery - Early Wenlock age (Gonzales de Juana et al., 1980; 444-426 Ma). Basal conglomerates of the El Horno Fm. unconformably overlie the Islitas tonalite (08VDL55, Fig. 2, Gonzales de Juana et al., 1980), which constrains exhumation of this intrusion to the Ordovician.

The Mucuchachi Formation (Fig. 2) unconformably overlies amphibolite facies metamorphic basement and mainly consists of green to black carbonaceous slates, shales and phyllites, which locally yield Pennsylvanian fauna (Odremán and Useche, 1997), although most sections have an undifferentiated Palaeozoic age (Gonzales de Juana et al., 1980). Shales from the Mucuchachi Fm. are intercalated with a $2000 \mathrm{~m}$ thick pile of volcanic tuffs associated with a volcanogenic massive sulphide deposit (Carlson, 1977; Staargaard and Carlson, 2000) at its westernmost exposure near Bailadores (08VDL15; Fig. 2). Low grade metasedimentary rocks of the Mucuchachi Fm. yield an imprecise $\mathrm{Rb} / \mathrm{Sr}$ whole rock isochron age of $293 \pm 30 \mathrm{Ma}$ (Burkley, 1976), which was interpreted to constrain the timing of metamorphism. The Mucuchachi Fm. is unconformably overlain by the middle Pennsylvanian Sabaneta Formation, which crops out near the city of Mérida and in the Caparo Block (Fig. 2). This sedimentary unit consists of fluvial and floodplain deposits that grade up into the Middle Permian marine sedimentary rocks of the Palmarito Formation (Laya and Tucker, 2012). The Palmarito Fm. may record a marine transgression in a foreland basin related to Permian orogenesis (Laya and Tucker, 2012). A sedimentary hiatus spans the Guadalupian ( 260 Ma) to the latest Triassic-earliest Jurassic, when an extensional regime led to the formation of grabens that host volcanic rocks and red siliclastic strata of the La Quinta Formation (Maze, 1984; Ostos et al., 2005; Barrett et al., 2008).

Several low grade metasedimentary units of unknown age unconformably overlie the high grade metamorphic basement complex. These include the Los Torres, Cerro Azul and El Aguila Suites, and are considered to be Palaeozoic (e.g. Schubert, 1969; Kovisars, 1971).

\subsection{The Santander Massif}

\subsubsection{Igneous-Metamorphic basement}

The Santander Massif is the northern continuation of the Eastern Cordillera of Colombia and forms the southwestern margin of the Maracaibo Triangular Block (Fig. 1). Its eastern boundary is defined by late Cainozoic thrusts that separate it from the Mérida Andes (Macellari, 1984). Northwards 
from Bucaramanga, its western margin is sharply defined by the Santa Marta - Bucaramanga Fault (SMBF) along a NNW trend, although similar basement units can be found on both sides of the same fault where it meets the Floresta Massif (Fig. 1).

The oldest unit exposed in the Santander Massif is the Bucaramanga Gneiss (Fig. 4), which consists of high grade pelitic to silicic paragneisses with lesser amphibolites, marbles and migmatites (Ward et al., 1974). Metamorphic conditions of the Bucaramanga Gneiss reach medium pressure - high temperature amphibolite facies conditions of 5.5 to $7.2 \mathrm{kbar}$ and 660 to $750^{\circ} \mathrm{C}$ in the central Santander Massif, with clockwise PT paths (García et al., 2005; Castellanos et al., 2008; UrueñaSuárez and Zuluaga, 2011). Many geochronological data have been collected from the basement of the Santander Massif (Fig. 5) and several analyses of the Bucaramanga Gneiss yield Precambrian ages. A hornblende gneiss to the west of Ocaña (Fig. 4) yields a hornblende K/Ar date of $945 \pm 40$ Ma (Ward et al., 1974). Chloritized hornblendes from the same area yield strongly disturbed ${ }^{40} \mathrm{Ar} /{ }^{39} \mathrm{Ar}$ spectra with individual steps spanning from 200 to $900 \mathrm{Ma}$ (Restrepo-Pace et al., 1997). Zircons from a stromatic migmatite in the Bucaramanga Gneiss yield discordant, multigrain $\mathrm{U}-\mathrm{Pb}$ data that define a discordia between $981 \pm 85 \mathrm{Ma}$ and 224 $\pm 76 \mathrm{Ma}$ (Restrepo-Pace and Cediel, 2010), suggesting that protoliths containing Proterozoic zircons experienced $\mathrm{Pb}$ loss or metamorphic overgrowth in the Triassic. Single grain zircon U-Pb SHRIMP analyses yield ${ }^{207} \mathrm{~Pb} /{ }^{206} \mathrm{~Pb}$ dates that range between 860 and $1200 \mathrm{Ma}$, which may reflect several magmatic and metamorphic episodes (Cordani et al., 2005).

The Silgará Formation mainly consists of phyllites, slates, quartzites and metasiltstones (Ward et al., 1974). It is inferred to overlie the Bucaramanga gneiss, and is overlain by mainly nonmetamorphic Middle Devonian sedimentary rocks of the Floresta Fm. in several locations (Ward et al., 1974; Boinet et al., 1986), which suggests that metamorphism occurred prior to the Middle Devonian. Contacts with the Bucaramanga Gneiss are difficult to identify and frequently follow isograds (Ward et al., 1974). Metamorphic assemblages from the Silgará Formation to the east of San Gil (Fig. 4) reveal a wide range of metamorphic conditions and a clockwise P-T path from 495$518^{\circ} \mathrm{C}$ at 4.4-5.5 kbar to peak pressures of $6.6-7.5 \mathrm{kbar}$ at $590-612^{\circ} \mathrm{C}$, and peak temperatures of 660-700 ${ }^{\circ} \mathrm{C}$ at 5.5-7.2 kbar (Ríos et al., 2003). Near Berlin (Fig. 4), the Silgara Formation reaches similar metamorphic conditions to the Bucaramanga Gneiss with peak temperatures of $630-704^{\circ} \mathrm{C}$ at pressures of 5-9.5 kbar (García et al., 2005; Castellanos et al., 2008). 
The Silgará Formation and the Bucaramanga Gneiss are both intruded by the strongly foliated quartzo-feldspathic Berlin Orthogneiss (Fig. 4). Previous studies of the microtexture and the structural and isograd concordance of this unit with its host metasedimentary rocks suggest that the emplacement of these bodies was coeval with metamorphism (Ward et al., 1974), which may have

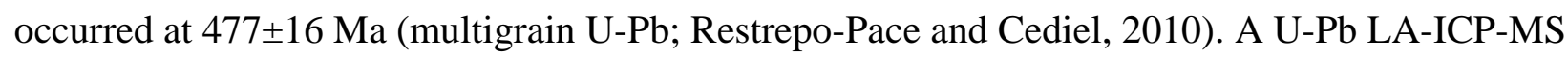
age of $477 \pm 2 \mathrm{Ma}$ was obtained from calc-alkaline metadiorites that intrude the Bucaramanga Gneiss and share a sub-parallel foliation with their host rock (Mantilla et al., 2012). The deformed rocks are intruded by undeformed Early Palaeozoic granitoids and numerous large Mesozoic batholiths of the Santander Plutonic Group (Fig. 4), which yield late Triassic to early Jurassic ages and have continental arc geochemistry (Fig. 5; Goldsmith et al., 1971; Dörr et al., 1995; Mantilla et al., 2013).

\subsubsection{Palaeozoic to Jurassic sedimentary rocks}

There are no recognised Early Palaeozoic sedimentary rocks in the Santander Massif and the metamorphic basement is unconformably overlain by Late Palaeozoic units. The Middle Devonian Floresta Fm. comprises marine sedimentary rocks that unconformably overlie the Silgará Fm in several locations (Ward et al., 1974; Boinet et al., 1986). These rocks, together with the overlying Late Carboniferous Diamante Fm., were metamorphosed under low grade conditions, but their isograd patterns do not coincide with those of the basement and metamorphism appears to be related to a different event that predates the deposition of the younger Tiburrón, Bocas, Jordan and Girón Formations (Ward et al., 1974). Within these overlying sedimentary rocks only the Bocas Fm. yields fossils, which include Glossopteris sp. and Classopollis sp., yielding a Jurassic age (Mojica et al., 1996 and references therein). However, the proposed Latest Permian extinction of Glossopteris (McLoughlin et al., 1997) questions the accuracy of this age determination. The Girón Fm. comprises a series of red beds that contain clasts of pink granitoids from the Triassic-Jurassic Santander Plutonic Group, and is unconformably overlain by Lower Cretaceous sedimentary rocks (Ward et al., 1974). Hence, its age may span the Jurassic.

\section{Previous models for the tectonic evolution of northwestern Gondwana}

Existing models place the basement rocks of the Mérida Andes and the Santander Massif into different terranes, namely the Mérida (Bellizzia and Pimentel, 1994; Aleman and Ramos, 2000) and Chibcha terranes (e.g. Ramos, 2009). These suspect terranes are inferred to be allochthonous because the Northern Andes host Precambrian to Early Palaeozoic metamorphic basement that lies outboard of Early Palaeozoic pericratonic basins (e.g. Llanos Basin, Fig. 1; Sempere, 1995). Models 
proposing an allochthonous Mérida Terrane argue that it formed on the northern margin of the Rheic Ocean and accreted to the autochthonous Caparo Block within Gondwana (Fig. 2) during the Carboniferous (Bellizzia and Pimentel, 1994; Aleman and Ramos, 2000). These models utilised ambiguous $\mathrm{Rb} / \mathrm{Sr}$ model dates (Fig. 3) to suggest that a Carboniferous arc formed on the Mérida Terrane as it converged with Gondwana. The inferred absence of metamorphism in Early Palaeozoic rocks to the south of the Caparo-Soledad Fault (Fig. 2) was used to suggest that it was the Rheic Ocean suture between the Mérida Terrane and the autochthonous Caparo Block of Gondwana. However, (i) the Caparo-Soledad Fault is an active reverse fault with dextral strike slip components and exposes deeper levels of the crust to the northwest, in its hanging wall (Audemard and Audemard, 2002), (ii) Early Palaeozoic metamorphic basement may extend to the Apure Fault, which underlies the the Llanos Basin (Fig 1; Feo-Codecido et al., 1984), (iii) stratigraphic differences across the Caparo-Soledad Fault include an absence of documented Triassic granitoids in its footwall (Figs. 2 and 3), challenging the hypothesis that this structural divide is a Carboniferous feature, (iv) the Caparo-Soledad fault exposes no high pressure metamorphic assemblage or any remnants of entrained oceanic crust, (v) the Cerro Azul Suite of Early Palaeozoic or older age appears to crop out on both sides of the fault near its northeastern termination (Schubert, 1969), and (vi) the model is constructed on the assumption that all pre-Cretaceous K/Ar and $\mathrm{Rb} / \mathrm{Sr}$ whole rock and mineral dates, and strongly discordant multigrain $\mathrm{U}-\mathrm{Pb}$ data (Fig. 3), are accurate crystallisation ages and are evidence for a Late Palaeozoic arc (Bellizzia and Pimentel, 1994; Aleman and Ramos, 2000). The published geochronological data can not be unambiguously interpreted as crystallisation ages given the evidence for several phases of deformation and metamorphism (Kovach et al., 1977; Maréchal, 1983). We will refer to the area north of the CaparoSoledad fault as the Mérida block, rather than the Mérida Terrane because there does not seem to be any clear evidence for oceanic separation or suturing between the Mérida and Caparo blocks, or any basis for considering it to be allochthonous to South America.

The Chibcha Terrane (e.g. Toussaint and Restrepo, 1988; Bellizzia and Pimentel, 1994) forms the basement of the Eastern Cordillera of Colombia and includes the Santander Massif, the Santa Marta Massif, the Périja Mountains, the Serranía de San Lucas and the Quetame Massif (Fig. 1). Existing models propose that the Chibcha Terrane formed part of Laurentia and collided with the passive margin of Gondwana in the Late Ordovician, forming a suture in the eastern Quetame Massif (Fig. 1; e.g. Ramos, 2009). Orogenesis during collision drove widespread deformation in the Quetame and Santander massifs (Forero Suarez, 1990; Ramos, 2009; Ramos, 2010; Restrepo-Pace and Cediel, 2010). However, (i) a Laurentian provenance is considered based upon similarities in 
Devonian fauna between Laurentia and the Northern Andes (Forero Suarez, 1990) instead of preOrdovician faunal similarities, which are required by the model of Ramos (2009; 2010), (ii) rocks from the eastern Quetame Massif interpreted as Ordovician ophiolitic remnants (Ramos, 2009; 2010) were either originally reported as submarine intracontinental volcanic rocks of unknown age (Ariari basalts; Cáceres et al., 2003) or are Silurian or younger gabbros and diorites that were emplaced into the Silurian Quetame Group (Forero Suarez, 1990; Ordóñez-Carmona et al., 2006), and are not ophiolites (e.g. Steinmann et al., 2003), and (iii) the Early Ordovician "graptolite facies" rocks interpreted as the autochthonous Gondwanan pre-collision passive margin by Ramos (2009), traverse across the proposed suture zone from southwest of the San Lucas Range (Fig. 1), which forms part of the "Chibcha Terrane" (Ordóñez-Carmona et al., 2006), to the eastern Llanos Basin (Fig. 1), which overlies cratonic basement (Mojica and Villarroel, 1990). The presence of Early Palaeozoic sedimentary basins inboard of Palaeozoic orogenic belts along the Gondwanan margin (e.g. Sempere, 1995) may be a result of a rise in global sea level by almost $200 \mathrm{~m}$ between the Early Cambrian and Late Ordovician (Haq and Schutter, 2008).

The Late Palaeozoic history of the Santander Massif is largely unconstrained by geochronological data (Fig. 5). Low grade metamorphism of the Late Carboniferous Diamante Fm. is considered to be coeval with a regional Late Permian metamorphic event within the Mérida Andes (Ward, 1974), which was inferred from Late Palaeozoic $\mathrm{Rb} / \mathrm{Sr}$ and $\mathrm{K} / \mathrm{Ar}$ dates. Regional models suggest that Latest Permian deformation recorded in the Sierra Nevada de Santa Marta and the Central Cordillera of Colombia (Fig. 1) may be related either to terrane accretion or increased plate coupling in a magmatic arc setting (e.g. Vinasco et al., 2006; Cardona et al., 2010). This period of compression was followed by Early to Middle Triassic extension recorded in the Central Cordillera of Colombia and in Ecuador by the formation of sedimentary basins and the coeval intrusion of TMORB amphibolites (e.g. Villagómez et al., 2011; Cochrane et al., 2014; Spikings et al., 2014). The effect of Early to Middle Triassic extension on the rocks of the Mérida Andes and the Santander Massif, where there are no known Triassic sedimentary rocks, is not clear.

The Mesozoic batholiths of the Santander Plutonic Group (Fig. 4) yield zircon U-Pb ages ranging from $\sim 210$ Ma to $\sim 196 \mathrm{Ma}$ and calc-alkaline, continental arc geochemistry (Fig. 5; Dörr et al., 1995; Mantilla et al., 2013), although all of these data were obtained from a relatively small area near our sample 10VDL52 (Fig. 4) in the central part of the Santander Massif. These granitoids are interpreted to have formed as a result of subduction of oceanic crust beneath a continental arc, and 
are older than arc related granitoids in the Central Cordillera (<189 Ma; Bustamente et al., 2011; Cochrane et al., 2014; Spikings et al., 2014).

\section{Analytical Methods}

\subsection{Zircon U-Pb Geochronology}

Weathered portions of samples were removed with a saw, and the remaining sample material was crushed with a jaw crusher. The crushed rock fraction was split and a representative fraction was separated for whole rock and isotope geochemistry. Zircons were extracted from the remainder of the crushed rock using conventional heavy liquid and magnetic mineral separation techniques. Hand picked, inclusion free, euhedral zircons were mounted in epoxy discs and polished to expose inner portions. The polished disks were coated in carbon and the internal structure of the zircons was imaged with cathodoluminescence on a CamScan MV2300 scanning electron microscope. Zircons were analysed for U-Pb geochronology on a Thermo Scientific Element XR ICP-MS at the Institute of Mineralogy and Geochemistry, University of Lausanne, Switzerland. Selected $35 \mu \mathrm{m}$ spots were ablated from zircons using a NewWave UP-193 ArF excimer ablation system at $5 \mathrm{~Hz}$ for 30 seconds, with a beam intensity of $2.2-2.6 \mathrm{~J} / \mathrm{cm}^{2}$. Ablated material was transported to the instrument using purified helium as a carrier gas. Primary standardization was made using GEMOC GJ-1 (CAID-TIMS ${ }^{206} \mathrm{~Pb} /{ }^{238} \mathrm{U}$ age of $600.5 \pm 0.4 \mathrm{Ma}$; Schaltegger et al., unpublished). The secondary

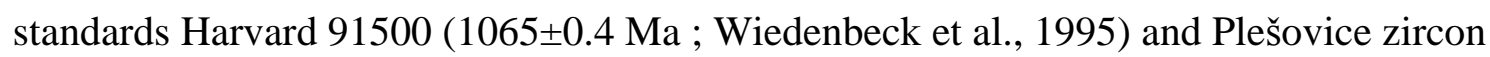
(337.13 $\pm 0.37 \mathrm{Ma}$; Slama et al., 2008) were utilised for calibration and routine monitoring of the consistency of measured U-Pb dates. Ages and uncertainties were calculated using LAMTRACE (Jackson, 2008) using the ratio of the mean intensities (Ulianov et al., 2012). Signals for every analysis were routinely monitored for isotopic fractionation, common $\mathrm{Pb}$ and $\mathrm{Hg}$-induced isobaric interference by inspection of time resolved intensity ratios and masses 204 and 202, respectively. Analyses with detectable $\mathrm{Hg}$ or common $\mathrm{Pb}$ were discarded. One secondary standard was measured for each three sample zircons, and measured average ages and their respective standard deviations

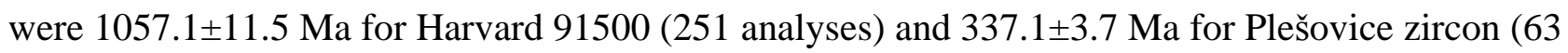
analyses). Statistical analysis of filtered data was performed using ISOPLOT 3.75 (Ludwig, 2003). For magmatic and metamorphic samples (Table 1), concordia plots were constructed and all discordant points were discarded unless they defined a discordia between two populations. Weighted mean ${ }^{206} \mathrm{~Pb} /{ }^{238} \mathrm{U}$ ages with a mean square of weighted deviates (MSWD) larger than 2.5 indicate excess scatter that may reflect either minor inheritance or $\mathrm{Pb}$ loss - our data was acquired without zircon chemical abrasion (e.g. von Quadt et al., 2014) and do not permit distinction between these possibilities. For detrital sample 08VDL05, random zircons were analysed and all 
points that were $>5 \%$ discordant were discarded. Dates included in the interpretation of data acquired from detrital zircons are ${ }^{206} \mathrm{~Pb} /{ }^{238} \mathrm{U}$ dates for analyses $<900 \mathrm{Ma}$, and ${ }^{207} \mathrm{~Pb} /{ }^{206} \mathrm{~Pb}$ dates for analyses $>900 \mathrm{Ma}$. All ages are reported with an analytical uncertainty of $\pm 2 \sigma$.

\subsection{Geochemistry}

Geochemical and $\mathrm{Pb}$ isotopic analyses were performed on representative whole rock powder fractions prepared using an agate mill. Major and trace elements were measured using a Philips PW2400 X-Ray Fluorescence (XRF) spectrometer. Additional trace elements and rare earth element abundances were measured at the University of Lausanne using a Perkin Elmer ELAN 6100 DRC quadrupole LA-ICP-MS on the fused glass disks used for XRF, with NIST SRM610 as the external standard. The GeoLas $200 \mathrm{M} 193 \mathrm{~nm}$ excimer laser was fired at $10 \mathrm{~Hz}$ with a spot size of $120 \mu \mathrm{m}$ and ablation energy of $140 \mathrm{~mJ}$. Sr concentration previously determined by XRF was utilised as the internal standard. When $\mathrm{Sr}$ concentration was lower than $100 \mathrm{ppm}$, the $\mathrm{CaO}$ concentration determined by XRF was used. Concentrations were calculated offline using LAMTRACE (Jackson, 2008), and the reported values are the averages of 3 spots per sample. Uncertainties between the results of repeated points of the same sample are estimated to be $<10 \%$ for REE and $<5 \%$ for the other trace elements.

\section{3. $\mathrm{Pb}$ isotope geochemistry}

$\mathrm{Pb}$ isotopic compositions were determined from whole rock powders of 36 igneous and metamorphic rocks. Approximately $100 \mathrm{mg}$ of whole rock powder was dissolved in $4 \mathrm{ml}$ of concentrated $\mathrm{HF}$ and $1 \mathrm{ml}$ of $15 \mathrm{M} \mathrm{HNO}_{3}$ in closed Teflon vials at $140{ }^{\circ} \mathrm{C}$ for seven days. The samples were dried down and re-dissolved in $3 \mathrm{ml}$ of $15 \mathrm{M} \mathrm{HNO}_{3}$ before being dried down again. $\mathrm{Pb}$ chemical separation was achieved following the methods outlined in Pin et al. (1997) and Chiaradia et al. (2011). Pb isotopic measurements were made using a Thermo Finnigan Triton Thermal Ionization Mass Spectrometer (TIMS) or a Nu Instruments Neptune MC-ICP-MS at the University of Geneva, Switzerland. Typical analytical uncertainties were $0.0075 \%$ on all measured ratios.

\section{Results}

\subsection{Petrology and geochronology}

The rock type nomenclature of igneous rocks (Table 1) is based on the geochemical classification of De La Roche et al. (1980). K/Ar dates or Rb/Sr model ages have previously been obtained from a majority of the rock units that we analysed (Figs. 3 and 5), and these are briefly referred to below. A summary of all new zircon U-Pb data is presented in Table 1 . 


\subsubsection{Caparo Block}

$\mathrm{U}-\mathrm{Pb}$ zircon ages were obtained from four granitoids of the Caparo Block (Fig. 2), which exhibit subsolidus deformation microfabrics of quartz with undulose extinction and variable grain size reduction. The oldest ${ }^{206} \mathrm{~Pb} /{ }^{238} \mathrm{U}$ age of $499.4 \pm 2.7 \mathrm{Ma}$ was obtained from the Cerro Azul granodiorite (08VDL35, Table 1; Fig. 2), which was sampled from a large river boulder within an alluvial fan that is fed by a stream which only drains the Cerro Azul pluton and phyllites of the Cerro Azul Formation. The coarse, non-foliated Tapo granite is located in the central part of the Caparo Block and yields a ${ }^{206} \mathrm{~Pb} /{ }^{238} \mathrm{U}$ age of $492.3 \pm 5.3 \mathrm{Ma}$ (08VDL57; Fig. 2; Table 1), providing a minimum Cambrian depositional age for the metasedimentary Bella Vista Suite, which it intrudes. The fine grained, two-mica El Cambur granite crops out $5 \mathrm{~km}$ upstream from granite 08VDL47 and gave a ${ }^{206} \mathrm{~Pb} /{ }^{238} \mathrm{U}$ age of $492.3 \pm 8.4 \mathrm{Ma}$ (08VDL56; Table 1). Finally, the youngest granitoid is the medium-grained Las Islitas hornblende-biotite tonalite, which yielded a ${ }^{206} \mathrm{~Pb} /{ }^{238} \mathrm{U}$ age of $473.1 \pm 3.5$ Ma (08VDL55; Table 1; Fig. 2). The tonalite is unconformably overlain by Early Llandovery ( 444 Ma: Gradstein et al., 2012) marine sedimentary rocks of the El Horno Formation (Burkley, 1976; Gonzales de Juana et al., 1980), indicating that the tonalite was unroofed by $444 \mathrm{Ma}$.

\subsubsection{Mérida Block}

\subsubsection{Metamorphic basement:Sierra Nevada Suite}

A paragneiss from the Sierra Nevada Suite (08VDL05; Fig. 2) hosts idiomorphic biotite and minor sillimanite indicating that it was metamorphosed at amphibolite facies conditions below the granitic solidus. Zircons lack metamorphic rims and yielded 109 concordant U-Pb age analyses, with peak ${ }^{206} \mathrm{~Pb} /{ }^{238} \mathrm{U}$ age probabilities at $\sim 525 \mathrm{Ma}, 700-550 \mathrm{Ma}, \sim 800 \mathrm{Ma}, \sim 1000 \mathrm{Ma}$, and $\sim 1100-1300 \mathrm{Ma}$ (Fig. 6). Minor peaks occur at $\sim 1350-1500 \mathrm{Ma}$ and $\sim 2000 \mathrm{Ma}$. The youngest detrital zircon yields an age of 505.0 $\pm 9.4 \mathrm{Ma}$, and the youngest cluster of 5 statistically equivalent analyses yields a weighted mean age of 518.7 $\pm 2.5 \mathrm{Ma}(\mathrm{MSWD}=0.83)$, which is interpreted to indicate the maximum depositional age for the sedimentary protolith.

Orthogneiss 08VDL11 resembles biotite microgranite with up to $\sim 10 \mathrm{~mm}$ elongated aggregates of fibrolitic sillimanite, and small grains of anhedral orthopyroxene. Grain boundaries are lobate, suggesting that this unit was partially melted and recrystallized. Muscovite replaces sillimanite (Fig. 7A) and muscovite and biotite form symplectites with myrmekite (Fig. 7B). These microtextures are typical of post-anatexis retrograde reactions (e.g. Peterman and Grove, 2010). An older population of four concordant analyses yields a weighted mean ${ }^{206} \mathrm{~Pb} /{ }^{238} \mathrm{U}$ age of $1008.6 \pm 6.7 \mathrm{Ma}$ 
(Fig. 8), which may represent the age of the magmatic protolith. A younger population of three concordant analyses yields a weighted mean ${ }^{206} \mathrm{~Pb} /{ }^{238} \mathrm{U}$ age of $454 \pm 10 \mathrm{Ma}$ (Table 1), which may reflect the timing of anatexis. Six analyses yield ages which define a chord between the two populations on a U-Pb Concordia diagram (Fig. 8).

The La Raya granitic gneiss (08VDL27) is an equigranular, muscovite - garnet leucogranite which yields a zircon ${ }^{206} \mathrm{~Pb} /{ }^{238} \mathrm{U}$ age of $488.5 \pm 6.5 \mathrm{Ma}$ (Fig. 2; Table 1). Muscovite is aligned and quartz grains have undulose extinction but grain boundaries do not exhibit any strain or recrystallisation. These features define a fabric which is indicative of syn-magmatic deformation (Passchier and Trouw, 2005). The La Raya gneiss and the adjacent Mitisus striped gneiss (08VDL26; Fig. 2) are considered to be parts of the Sierra Nevada Suite (Schubert, 1969). The microtexture of Mitisus gneiss 08VDL26 features aligned quartz ribbons in addition to macroscopic quartz and feldspar augen porphyroclasts with small biotite crystals in strain shadows (Fig. 7C), which may have formed during high grade sub-solidus shearing (Passchier and Trouw, 2005). Analysed zircons from the Mitisus gneiss yield a range of concordant, non-equivalent ages, which may be a result of $\mathrm{Pb}$ loss during deformation. The oldest group of equivalent, concordant analyses yield a weighted mean ${ }^{206} \mathrm{~Pb} /{ }^{238} \mathrm{U}$ age of $488.2 \pm 4.3 \mathrm{Ma}(\mathrm{n}=6 ; \mathrm{MSWD}=2.0)$, which is statistically equivalent to the age of the adjacent La Raya granitic gneiss (488.5 $\pm 6.5 \mathrm{Ma}$ ), suggesting that the Mitisus striped gneiss may be a sheared member of the latter. The foliation planes of the Mitisus striped gneiss are roughly parallel to the Boconó Fault system (Schubert, 1969, Audemard and Audemard, 2002) and dip steeply to the SE, with a NE-SW strike direction. The timing of high-grade deformation of this unit is not constrained by our data.

Strongly foliated augen gneisses of the Sierra Nevada Suite near Puente Real (08VDL36; Fig. 2) yield a weighted mean zircon ${ }^{206} \mathrm{~Pb} /{ }^{238} \mathrm{U}$ age of $472.3 \pm 3.4 \mathrm{Ma}$ (Table 1). Burkley (1976) utilised structural observations to conclude that the Puente Real gneiss was emplaced during metamorphism. Our sample has a metamorphic overprint defined by quartz recrystallisation and the growth of epidote, which may reflect post-magmatic deformation under greenschist conditions.

A strongly foliated gneiss from the Sierra Nevada Suite was collected at La Playita (08VDL22; Fig. 2), and yields a zircon ${ }^{206} \mathrm{~Pb} /{ }^{238} \mathrm{U}$ age of $449.7 \pm 4.4 \mathrm{Ma}$ (Table 1). Larger biotite and feldspar porphyroclasts define an augen texture, whereas smaller biotite and muscovite crystals are undeformed and aligned. Quartz crystals between the mica layers are preferably elongated and 
partially recrystallized, suggesting that much of the deformation in our sample arose from post magmatic low to medium grade shearing (Passchier and Trouw, 2005).

\subsubsection{Granitoids intruding the Iglesias Complex}

Zircon U-Pb ages are reported from eleven granitoids which intrude the Iglesias Complex metamorphic basement. These units are generally unfoliated and yield weighted mean Early

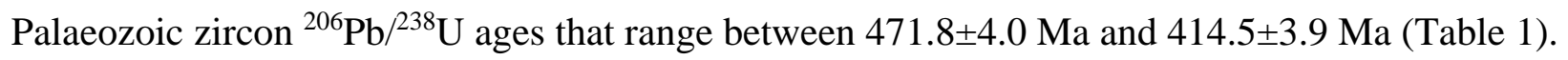

A rhyolitic tuff (08VDL15) from the footwall of the Bailadores volcanogenic massive sulphide (VMS) deposit (Carlson, 1977; Staargaard and Carlson, 2000) yields a weighted mean zircon ${ }^{206} \mathrm{~Pb} /{ }^{238} \mathrm{U}$ age of $452.6 \pm 2.7 \mathrm{Ma}$. The $1-2 \mathrm{~km}$ thick tuffs unconformably overlie the Sierra Nevada Suite and are interfingered with low grade metasedimentary rocks of the Mucuchachi Formation at their top (Carlson, 1977). VMS mineralisation is of the bimodal-siliciclastic or Kuroko type (Staargaard and Carlson, 2000), suggesting that the tuffs were deposited in a basin over the metamorphic basement.

The Pueblo Hondo biotite granite (08VDL04) has a surface area of $\sim 200 \mathrm{~km}^{2}$ (Fig. 2), intrudes the Tostos Suite, and yields a weighted mean zircon ${ }^{206} \mathrm{~Pb} /{ }^{238} \mathrm{U}$ age of $434.2 \pm 4.4 \mathrm{Ma}$. The Soledad granodiorite (08VDL32) gave the youngest Palaeozoic zircon mean ${ }^{206} \mathrm{~Pb} /{ }^{238} \mathrm{U}$ age in the Mérida Andes of 414.5 $\pm 3.9 \mathrm{Ma}$. The emplacement of this unit generated an andalusite hornfels contact aureole in the Cerro Azul Suite (Gonzales de Juana et al., 1980), indicating an Early Devonian minimum age for the host rock. The Cerro Azul Suite crops out on both sides of the Caparo-Soledad fault (Schubert, 1969), and its Early Palaeozoic or older age suggests that basement blocks on either side of that fault were continuous in the Early Palaeozoic, challenging the hypothesis that the Caparo Soledad Fault is a Carboniferous suture (Bellizzia and Pimentel, 1994; Aleman and Ramos, 2000).

Four granitoids and one dacite collected from the Mérida Andes yield Triassic weighted mean

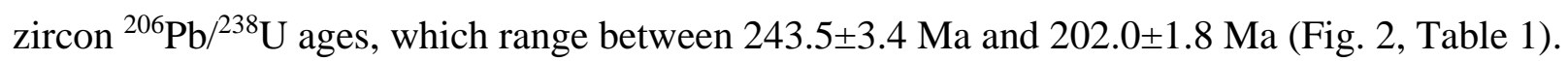

The basal interval of the syn-rift La Quinta Formation (e.g. Maze, 1984) is composed of $\sim 150 \mathrm{~m}$ thick biotite bearing rhyodacite tuffs (08VDL18; Fig. 2), which yield a zircon U-Pb age of 202.0 $\pm 1.8 \mathrm{Ma}$ (Table 1). The tuffs unconformably overlie Palaeozoic low grade metasedimentary rocks of the Mucuchachi Fm. The La Quinta Formation includes all non-metamorphic, red 
continental siliciclastic rocks in the Mérida Andes, and published palaeontological data suggest that the top of the formation may be as young as Cretaceous (Maze, 1984). Our U-Pb age of 202.0 \pm 1.8 Ma is a maximum age for the base of the La Quinta Fm in the Merida Andes.

\subsubsection{Granitoids from isolated outcrops in Venezuela}

Three magmatic intrusions were collected from isolated outcrops located around the northern shore of Lake Maracaibo (Fig. 1). The Amparo hornblende-biotite diorite (08VDL64), located in the centre of the Paraguaná peninsula yields a weighted mean zircon U-Pb age of $272.2 \pm 2.6 \mathrm{Ma}$ (Fig. 1). The pluton is unconformably overlain by Upper Jurassic sedimentary rocks (Odremán and Useche, 1997).

Toas Island (Fig. 1) is composed of an outcrop of granitic basement along the Oca Fault, which forms the northern boundary of the Maracaibo Block. The Toas Island granodiorite (08VDL59) gave a zircon $\mathrm{U}-\mathrm{Pb}$ age of $248.9 \pm 1.7 \mathrm{Ma}$ and is locally overlain by red sandstones of the Mesozoic La Quinta Formation.

A weathered pink equigranular biotite granite was collected from the foothills of the Serranía del Perijá (Fig.1; 08VDL60), which yielded a zircon U-Pb age of 225.1 $1.5 \mathrm{Ma}$. This granite is unconformably overlain by Jurassic rocks of the La Quinta Formation (e.g. Maze, 1984; Shagam et al., 1984).

\subsubsection{Santander Massif}

\subsubsection{Metamorphic Basement}

The Bucaramanga gneiss (Fig. 4), located in the central Santander Massif, hosts subparallel stromatic leucosomes which locally form isoclinal s-folds. An undeformed decimetric dike of the Mesozoic Santander Plutonic Group crosscuts foliation of the outcrop. Leucosome 10VDL50 is composed mainly of quartz, feldspar, plagioclase and minor biotite. Many zircons from this sample are rounded, suggesting that they were inherited from a sedimentary protolith. Rims from 9 euhedral zircons yield a ${ }^{206} \mathrm{~Pb} /{ }^{238} \mathrm{U}$ age of $477.0 \pm 5.3 \mathrm{Ma}$, with a large scatter (MSWD = 7.5; Table 1) that may be a result of accidental analysis of small zircon cores or partial $\mathrm{Pb}$ loss, possibly during intrusion of the crosscutting dike.

A second sample of Bucaramanga Gneiss (10VDL23) forms alternating $5 \mathrm{~cm}$ thick bands. The dark bands are mainly composed of hornblende and feature plagioclase poikiloblasts incorporating 
hornblende and chlorite, which alternate with leucocratic bands composed mainly of plagioclase, minor hornblende and fresh biotite. Zircon forms inclusions in all major mineral phases in both bands, and all 18 analysed oscillatory zoned zircons define a single population with a weighted mean age of 461.0 $\pm 2.1 \mathrm{Ma}$. These relationships suggest that this rock had a mafic to intermediate igneous protolith which underwent post-magmatic deformation at lower amphibolite facies. Our zircon $\mathrm{U}-\mathrm{Pb}$ age most likely records the time of crystallisation of the igneous protolith.

A foliated granite of the Berlin Orthogneiss (10VDL44; Fig. 4) hosts thin shear zones with http://www.geosociety.org/pubs/editorsCall.htm muscovite, biotite and epidote that define a strong foliation, although it is unclear from the microtexture of our sample whether or not deformation was syn- or post-magmatic. Oscillatory zoned zircon rims yield a weighted mean zircon ${ }^{206} \mathrm{~Pb} /{ }^{238} \mathrm{U}$ age of $473.6 \pm 2.5 \mathrm{Ma}$.

A sample of granodiorite orthogneiss from the Páramo de Berlin (10VDL51) contains biotite and minor fibrolitic sillimanite which define a strong foliation around aggregates of felsic minerals. Unaligned but slightly undulose quartz forms highly lobate grain boundaries and fills holes in aligned biotite, which suggests that melt was present after grain alignment. Migmatites are absent from the outcrop. Seventeen zircons yield concordant dates that range between 483.3 $\pm 5.7 \mathrm{Ma}$ and $462.7 \pm 3.5 \mathrm{Ma}$, and define a weighted mean ${ }^{206} \mathrm{~Pb} /{ }^{238} \mathrm{U}$ age of $472.5 \pm 3.4 \mathrm{Ma}$. The high age dispersion $(\mathrm{MSWD}=11.5$, Table 1$)$ suggests that zircons from this sample may either record both crystallisation and subsequent anatexis or include some small xenocrystic cores which were not detectable by cathodoluminescence image analysis. Alternatively, zircons may have undergone minor $\mathrm{Pb}$ loss as a result of reheating during the intrusion of the Páramo Rico pluton at $\sim 205 \mathrm{Ma}$ (Dörr et al., 1995), as suggested by early Jurassic K/Ar (biotite) dates obtained from biotite gneiss in this area (Goldsmith et al., 1971).

A tonalitic hornblende-biotite orthogneiss (10VDL37) forms a sill that intrudes the Silgará Formation and yields a zircon ${ }^{206} \mathrm{~Pb} /{ }^{238} \mathrm{U}$ age of $451.5 \pm 1.3 \mathrm{Ma}$. The host rocks at this location (Fig. 4; Table X) have a lower metamorphic grade (Ward et al., 1974). Foliation in this sample is less regular and defined by slightly folded biotite, which is wrapped around dislocation-rich plagioclase porphyroclasts, indicating that deformation in this rock may have occurred below the solidus. This sill is crosscut by deformed migmatitic leucosomes (10VDL39) and undeformed dikes (Fig. 9). Leucosome 10VDL39 yields a weighted mean ${ }^{206} \mathrm{~Pb} /{ }^{238} \mathrm{U}$ age of $208.8 \pm 1.2 \mathrm{Ma}$. 
An undeformed pegmatite (10VDL43) crosscuts the foliation of the host orthogneiss and contains zircons which yield two distinct $\mathrm{U}-\mathrm{Pb}$ age populations with weighted mean ages of $460.3 \pm 3.5 \mathrm{Ma}$ (6 analyses; Table 1) and 209.2 \pm 3.4 Ma (5 analyses, Table 1). Additional analyses from 6 zircons define a discordia between these two age populations. We interpret the older population as the age of the orthogneiss host rock, and the younger population as the crystallisation age of the pegmatite.

Fine grained, massive hornblende-biotite gneiss from the north-northwest of Pamplona (10VDL49; Fig. 4) contains oscillatory zoned zircons that yield a weighted mean zircon ${ }^{206} \mathrm{~Pb} /{ }^{238} \mathrm{U}$ age of 479.8 \pm 3.1 Ma. The gneiss is mapped as the Silgará Formation and has a dark matrix with aligned hornblende and biotite, and fine leucocratic bands giving it a strong foliation. Plagioclase in this rock is mostly replaced by prehnite and epidote, revealing a low grade metamorphic overprint.

\subsubsection{Palaeozoic plutons}

Three unfoliated plutonic rocks which crop out in the Santander Massif yield Early Palaeozoic weighted mean zircon ${ }^{206} \mathrm{~Pb} /{ }^{238} \mathrm{U}$ ages of $483.7 \pm 5.9$ (10VDL47), 443.4 $\pm 3.2 \mathrm{Ma}$ (10VDL55) and 439.2 $\pm 4.7 \mathrm{Ma}$ (10VDL46). The oldest of these, gabbrodiorite 10VDL47, was collected from a $3 \mathrm{~m}^{3}$ boulder which lay below a ridge, and a local source was inferred although its field relationships are unclear. The two younger granitoids crosscut foliation of the Silgará Formation and thus postdate regional metamorphism.

A dike of grey vesicular porphyritic rhyolite crosscuts the Bocas Formation to the west of the Santa Marta - Bucaramanga Fault (Fig. 4; 10VDL58). The strained nature of some quartz grains compared with the generally round shape of vesicles suggests that this rock was contaminated by older material, which is reflected in the zircon $\mathrm{U}-\mathrm{Pb}$ ages. The youngest coeval zircons $(\mathrm{n}=6)$ yield a weighted mean ${ }^{206} \mathrm{~Pb} /{ }^{238} \mathrm{U}$ age of $250.7 \pm 4.3 \mathrm{Ma}$, and 10 inherited grains have ages that range

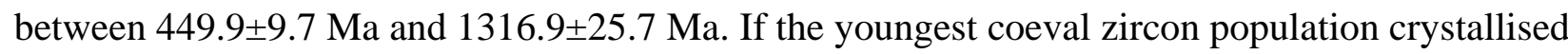
from the rhyolitic melt, then the Bocas Fm. is Permian or older, although a range of ages from Carboniferous to Jurassic were previously assigned to this unit (Ward et al., 1974; Mojica et al., 1996).

\subsubsection{Mesozoic igneous rocks}

Intermediate to felsic granitoids of the Triassic - Jurassic Santander Plutonic Group (Fig. 4) are exposed over a surface area of more than $4000 \mathrm{~km}^{2}$ (Fig. 4) and yield 11 weighted mean ${ }^{206} \mathrm{~Pb} /{ }^{238} \mathrm{U}$ zircon ages ranging between $202.2 \pm 1.0$ and 195.8 $\pm 1.5 \mathrm{Ma}$ (Table 1). Several of these rocks have 
porphyritic or granophyric textures suggesting that they cooled rapidly at shallow levels in the crust. Granodiorite 10VDL61 contains numerous 1-20 cm sized mafic enclaves composed of biotite pseudomorphed by epidote, with corundum, white mica and sericite. Euhedral zircons from this sample yield two populations (Table 1), which are (i) a younger population of 10 grains with a weighted mean ${ }^{206} \mathrm{~Pb} /{ }^{238} \mathrm{U}$ age of $200.0 \pm 1.5 \mathrm{Ma}$, which we interpret to be the crystallisation age of the granodiorite, and (ii) an older population of 6 grains that yield a weighted mean ${ }^{206} \mathrm{~Pb} /{ }^{238} \mathrm{U}$ age of $1018.3 \pm 8.9 \mathrm{Ma}$ (Fig. 10), which may be related to the numerous mafic enclaves. The mineral assemblage of these enclaves suggests either a pelitic or silica undersaturated igneous protolith, although we favour a metaigneous protolith because of the euhedral shape and age distribution of the zircons in two distinct, clearly defined populations.

\subsection{Geochemistry}

The granitoids and felsic volcanic rocks exposed in the Santander Massif and the Mérida Andes have a wide range of $\mathrm{SiO}_{2}$ content ranging from $54 \%$ to $75 \%$ and generally plot along a high-K calc-alkaline trend (Fig. 11A). Most of the Phanerozoic igneous rocks are mildly to strongly peraluminous although rocks in the Santander Massif are generally less peraluminous than coeval igneous rocks in the Mérida Andes (Fig. 11b). The large range in Shand's Index (A/CNK; Maniar and Piccoli, 1989) suggests that some of the studied granitoids may be derived from the anatexis of pelitic rocks, while others may be derived from igneous sources. Large variations in $\mathrm{Na}_{2} \mathrm{O}$ compared to $\mathrm{K}_{2} \mathrm{O}$ (Fig. 11c) suggest that both S- and I-Type granitoids (Chappell and White, 1974) were coeval. For example, monzodiorite 08VDL47 and granodiorite 08VDL45 are coeval within uncertainty (Table 1) and were collected from the same batholith, although the former is mildly peraluminous ( $\mathrm{A} / \mathrm{CNK}=1.03$, appendix) and plots in the I-Type field (Fig. 11c), whereas the latter 08VDL45 is strongly peraluminous (A/CNK=1.20, appendix) and plots in the S-Type field (Fig. 11c). Early Palaeozoic igneous rocks may be a result of mixing of variable proportions of melts derived from different sources (e.g. Patiño-Douce, 1999; Maas et al., 1997).

Late Triassic to Jurassic granitoids from the Santander Massif are mildly peraluminous and have $\mathrm{K}_{2} \mathrm{O}$ and $\mathrm{Na}_{2} \mathrm{O}$ compositions typical of I-Type granites (Fig. 11c), corroborating the presence of hornblende and titanite. In contrast, late Triassic granitoids from Venezuela are more peraluminous with muscovite and biotite as coexisting phases, and contain $\mathrm{K}_{2} \mathrm{O}$ and $\mathrm{Na}_{2} \mathrm{O}$ compositions typical of both I- and S-Type granites. 
The magmatic rocks yield trace element compositions that are very similar to average upper continental crust (Taylor and McLennan, 1985), with the exception of $\mathrm{Nb}$ and Ta concentrations, which are depleted in rocks of all age groups (Fig. 12). The low $\mathrm{Nb}$ and Y contents of most rocks (Fig. 11d) are characteristic of rocks that formed in convergent margins (Pearce, 1996). REE abundances are generally similar to upper continental crust, with variable positive or negative europium anomalies (Fig. 12).

\section{3. $\mathrm{Pb}$ isotope geochemistry}

Thirty-six intrusive and volcanic rocks from the studied regions yield present day $\mathrm{Pb}$ compositions with more radiogenic ${ }^{207} \mathrm{~Pb} /{ }^{204} \mathrm{~Pb}$ compared to ${ }^{206} \mathrm{~Pb} /{ }^{204} \mathrm{~Pb}$ ratios relative to the Stacy and Kramers (1975) terrestrial Pb evolution curve (Fig. 13, Table 2). Samples collected from the Mérida Block, the Caparo Block and the Santander Massif yield indistinguishable Pb isotopic trends (Fig. 13). Rocks from Toas Island, the Perijá Foothills and the Paraguana Peninsula yield slightly more juvenile $\mathrm{Pb}$ compositions, although they lie on the same general trend. The crustal evolution trend of all analysed samples is similar to that of rocks exposed in the Guyana Shield in southern Venezuela, the Garzón Massif in Colombia and the Amazonian Craton in western Brazil (Fig. 13). In contrast, Laurentian cratonic rocks or the Laurentia - derived Cuyania Terrane (e.g. Astini et al., 1995 and references therein) yield very different trends, which lie below the terrestrial $\mathrm{Pb}$ evolution curve (Fig. 13).

\section{Interpretation}

\subsection{Periods of magmatic activity in Venezuela and the Santander Massif}

\subsubsection{Late Mesoproterozoic}

An orthogneiss (08VDL11) and a granodiorite (10VDL61) of the Sierra Nevada Suite and the Santander Plutonic Group, respectively, yield two populations of zircons. The older, concordant

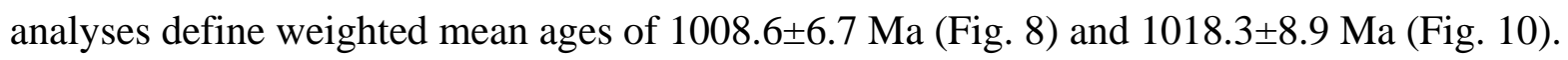
Orthogneiss 08VDL11 underwent anatexis at $454 \mathrm{Ma}$, whereas granodiorite 10VDL61 may have crystallised at $\sim 200 \mathrm{Ma}$ while incorporating Proterozoic material. These older populations provide indirect evidence for $\sim 1 \mathrm{Ga}$ basement in the Mérida Andes and support previous hypotheses that $\sim 1$ Ga basement is present in the central Santander Massif (Fig. 1; e.g., Restrepo-Pace et al., 1997), although it was largely reworked by Phanerozoic magmatism and metamorphism. Reliable U-Pb data and Sm-Nd isochrons reveal the presence of $\sim 1$ Ga basement in the northern Santander Massif, the Sierra Nevada de Santa Marta, the Garzón Massif and beneath the Llanos Basin (Fig. 1, e.g. 
Restrepo-Pace et al., 1997; Cordani et al., 2005; Ibanez-Mejia et al., 2011), and rocks with similar ages can be found along extensive tracts of the Andean margin (e.g. the Arequipa Terrane; Ramos, 2010 and references therein).

\subsubsection{Late Neoproterozoic}

Late Neoproterozoic rocks were not sampled in this study, although previous authors (Aleman and Ramos, 2000; Chew et al., 2008) infer that they exist within the Mérida Andes based on a Rb/Sr model age and U-Pb data (Fig. 3; Compañia Shell de Venezuela and Creole Petroleum Corporation, 1964; Burkley, 1976). However, (i) all of the Late Neoproterozoic U-Pb dates obtained from the Mérida Andes are strongly discordant (Burkley, 1976) and their accuracy is questionable, and (ii) no supporting data for the $\mathrm{Rb} / \mathrm{Sr}$ model age of $\sim 660 \mathrm{Ma}$ (Compañia Shell de Venezuela and Creole Petroleum Corporation, 1964) has been published and its age may be anomalously old because of incorporated excess ${ }^{87} \mathrm{Sr}$ during crystallisation. The only precise Late Neoproterozoic U-Pb data from Venezuela or Colombia are a zircon U-Pb age of 577.8+6.3/-9 Ma (LA-ICP-MS; Arango Mejía et al., 2012) obtained from a nepheline syenite with within-plate geochemistry, located in an inlier in the Llanos Basin (Fig. 1). There is stronger evidence for Neoproterozoic basement in Perú ( 752 Ma - $691 \mathrm{Ma}$; Chew et al., 2008; Mišković et al., 2009) than in the Andes of Colombia and Venezuela.

\subsubsection{Early Palaeozoic}

The Mérida Andes and the Santander Massif host Early Palaeozoic magmatic rocks which yield ${ }^{206} \mathrm{~Pb} /{ }^{238} \mathrm{U}$ ages that range between $499.4 \pm 2.7-414.5 \pm 3.9 \mathrm{Ma}$ and $483.7 \pm 5.9-439.2 \pm 4.7 \mathrm{Ma}$, respectively (Fig. 14). In Venezuela, Early Palaeozoic igneous rocks are also found in the Caribbean Mountains (Sisson et al., 2005), the El Baúl Massif (Viscarret et al., 2009) and in the Llanos Basin (Feo-Codecido et al., 1984) north of the Apure Fault (Fig. 1). Early Palaeozoic magmatism in Colombia is also recorded in the Quetame and Floresta massifs of the Eastern Cordillera (Fig. 1), where granitoids yield zircon $\mathrm{U}-\mathrm{Pb}$ ages that range between 520 and $420 \mathrm{Ma}$ (Horton et al., 2010), and it occurs in the Central Cordillera (La Miel Gneiss; e.g. Villagómez et al., 2011).

Published in-situ U-Pb zircon ages from all basement regions in the Northern Andes (Fig. 1) suggest that a regional magmatic hiatus lasted from $\sim 415 \mathrm{Ma}$ until $294 \mathrm{Ma}$. This observation is supported by a paucity of Devonian to Carboniferous detrital zircons in the Eastern Cordillera of Colombia (Horton et al., 2010). We do not consider the previous two Devonian U-Pb dates from the 
Caparo Block (Fig. 3; Burkley, 1976) to be accurate because (i) a lower intercept date of $350 \pm 50$ Ma was obtained from a mix of rounded zircons and unidentified material (not zircon; Burkley, 1976) extracted from a metasedimentary rock, and its significance is unclear, and (ii) the $390 \pm 30$ Ma date is a ${ }^{207} \mathrm{~Pb} /{ }^{206} \mathrm{~Pb}$ intercept from discordant data resulting from large amounts of incorporated common $\mathrm{Pb}$ (Burkley, 1976).

The only Permian granitoid analysed during this study is the El Amparo Diorite, which crops out in the Paraguana Peninsula (08VDL64; 272.2 $\pm 2.6 \mathrm{Ma}$; Fig. 1). This intrusion is located in the Bonaire Block, which has accommodated dextral displacement between the Caribbean and the South American plates since the Palaeocene (e.g. van der Lelij et al., 2010). Several Permian granitoids crop out in the Sierra Nevada de Santa Marta (Fig. 1; Cardona et al., 2010), the Central Cordillera of Colombia (Cochrane et al., 2014) and the El Baúl Massif (Fig. 1; Viscarret et al., 2009), which are interpreted to be continental arc rocks.

\subsubsection{Mesozoic}

Early to Middle Triassic U-Pb ages were obtained from small granitic bodies in the Perija foothills, Toas Island, Mérida Andes and a rhyolitic dike crosscutting the Bocas Fm. in the Santander Massif (Fig. 14; Table 1). Permian to Middle Triassic igneous and metamorphic rocks are widespread in the Central Cordillera of Colombia and the Sierra Nevada de Santa Marta (e.g. Vinasco et al., 2006; Montes et al., 2010; Restrepo et al., 2011; Villagómez et al., 2011; Spikings et al., 2014). Late Triassic to Early Jurassic magmatism may have been relatively continuous in the Mérida Andes and

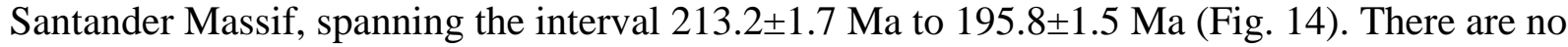
known coeval magmatic rocks in the rest of the Northern Andes, and the earliest Jurassic magmatism in the Central Cordillera (Fig. 1) commenced at 189 Ma (Bustamante et al., 2010).

\subsection{Conditions and timing of metamorphism}

\subsubsection{Mérida Block}

The Sierra Nevada Suite underwent amphibolite facies Barrovian metamorphism characterised by clockwise PT paths (e.g., Grauch, 1972). The youngest detrital zircon within amphibolitic metasedimentary rocks of the sampled Sierra Nevada Suite yields a ${ }^{206} \mathrm{~Pb} /{ }^{238} \mathrm{U}$ age of $505.0 \pm 9.4 \mathrm{Ma}$, representing a maximum stratigraphic age. Structural mapping suggests that some granitoids were emplaced prior to or during metamorphism (e.g. Schubert, 1969; Kovach et al., 1977), and existing maps include these foliated granitoids within the Sierra Nevada Suite metamorphic basement complex. Four foliated magmatic rocks from the basement complex yield ages ranging between 


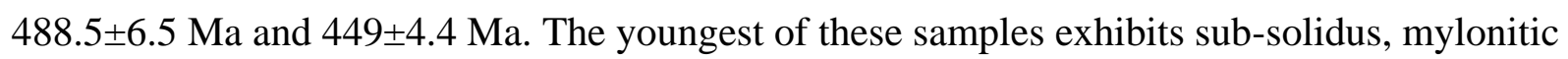
deformation and is located close to the Boconó Fault, suggesting that its deformation may be unrelated to a regional metamorphic event.

The foliation of the Sierra Nevada Suite is crosscut by numerous granitoids with ages that range

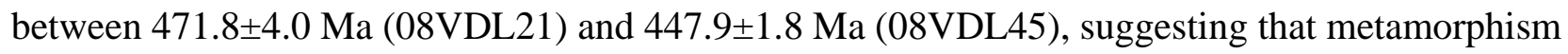
occurred in the interval $\sim 505-472 \mathrm{Ma}$. A biotite-muscovite-sillimanite orthogneiss (08VDL11; Fig. 2) sampled from the same fault block studied by Grauch (1972) exhibits a microtexture that is typical of retrogression from partial melting, and we interpret the younger population ( $454 \pm 10 \mathrm{Ma}$; Fig. 8; Table 1) to reflect the timing of anatexis under upper amphibolite facies conditions during retrogression. Many Early Palaeozoic granitoids have epidote and chlorite replacing amphibole and biotite, suggesting low grade alteration.

\subsubsection{Caparo Block}

The greenschist grade Bella Vista phyllites of the Caparo Block were intruded by non-deformed to weakly foliated granitoids between $\sim 492 \mathrm{Ma}$ and $\sim 473 \mathrm{Ma}$ (Fig. 14), and are unconformably overlain by the strongly folded but non-metamorphosed Late Ordovician Caparo Formation (Odremán and Useche, 1997). This suggests that the Caparo Block was exhumed before the Late Ordovician. Field relationships are not sufficiently clear to determine the temporal relationship between the small intrusions in the Caparo Block and the metamorphism of the host rock, but the Late Ordovician Caparo Fm. (Gonzales de Juana et al., 1980) provides a minimum age for the greenschist facies metamorphism of the Bella Vista Suite.

\subsubsection{Santander Massif}

Recent studies describe medium pressure, Barrovian metamorphism of the Bucaramanga Gneiss and the Silgará Formation in the central Santander Massif (García et al., 2005; Castellanos et al., 2008; Urueña-Suárez and Zuluaga, 2011). In this locality, isograd boundaries have a north-south orientation and metamorphic grades of the Silgará Fm. increase westwards towards the Bucaramanga Gneiss, near samples 10VDL50 and 10VDL51 (Fig. 4). A leucosome within the Bucaramanga Gneiss (10VDL50) was sampled in the highest grade zone in the central Santander

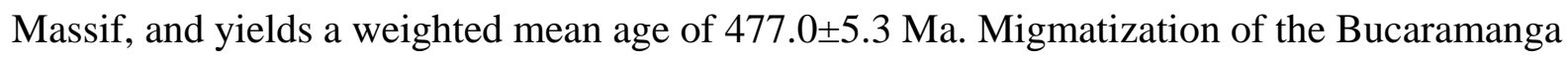
gneiss may have occurred near peak conditions, and this Early Ordovician age is our best estimate for the timing of peak metamorphism in this region. 
The regional metamorphic foliation of the Bucaramanga Gneiss and Silgará Formation is parallel with the pre-full crystallisation foliation of the intruding orthogneiss units (Ward et al., 1974). Recent work suggests that the orthogneiss in the central Santander Massif was deformed as it intruded during metamorphic retrogression (García et al., 2005; Castellanos et al., 2008), which is consistent with our petrographic observations. A sample of sillimanite orthogneiss from the central Santander Massif yields an Early Ordovician age (472.5 $\pm 3.5 \mathrm{Ma}$; 10VDL50), coeval with intrusion of orthogneiss 10VDL44 at 473.5 $\pm 2.5 \mathrm{Ma}$ in the eastern Santander Massif near Pamplona (Table 1, Fig. 4). These relationships suggest that the basement rocks of the central Santander Massif were on the retrograde path above the sillimanite isograd at $\sim 472 \mathrm{Ma}$ The foliation of the orthogneiss and the Silgará Formation is crosscut by the undeformed Pamplona Granite (10VDL46, Ward et al., 1974), suggesting that regional metamorphism had terminated by 439.2 $\pm 4.7 \mathrm{Ma}$. Consequently, Barrovian metamorphism may have been coeval in the Mérida Andes and the Santander Massif.

Ordovician U-Pb ages of 461.0 $22.1 \mathrm{Ma}$ (10VDL23) and 451.5 Ma (10VDL37) have been obtained from the Bucaramanga Gneiss and orthogneiss. These rocks show evidence for post-magmatic deformation at upper greenschist to lower amphibolite facies conditions, and our age data from cross-cutting rocks indicate that they were deformed before $209 \mathrm{Ma}$ (Fig. 9). Clockwise PT paths indicating similar conditions to the central Santander Massif have been obtained from rocks of the Silgará Formation in the southwestern Santander Massif (Ríos et al., 2003). Our age data only constrain metamorphism in the southwestern Santander Massif to have occurred prior to $\sim 199.1 \pm 1.3$ Ma (granodiorite 10VDL22; Fig. 4).

\subsection{The Northern Andes: autochthonous blocks or allochthonous terranes?}

Several lines of evidence strongly support an autochthonous origin for the basement sequences of the Merida Andes and the Santander Massif. First, the basement rocks from the Caparo Block, Mérida Andes and the Santander Massif collectively yield $\mathrm{Pb}$ isotopic ratios which plot in a narrow field (Fig. 13), suggesting that they originated from crustal sources with a similar magmatic and metamorphic history. Their isotopic composition is compatible with crustal sources within the Amazonian Craton and the Guyana Shield, but it is distinct from Laurentian Grenvillian-aged basement. MP-HT metamorphism occurred between $~ 505 \mathrm{Ma}$ and $472 \mathrm{Ma}$ in both the Santander Massif and the Mérida Andes (Fig. 14), and was coeval with unconformities between metamorphic basement and Late Ordovician sedimentary rocks in the Caparo Block, which suggests that all three areas were on the same margin during the Early Palaeozoic. The lower degree of metamorphism 
within the exposed basement rocks of the Caparo Block may be related to differential exhumation along the northwest dipping Caparo-Soledad reverse fault (Fig. 2; e.g. Colletta et al., 1997).

Second, Late Neoproterozoic ages were obtained from more than a third of the detrital zircons in Sierra Nevada gneiss 08VDL05 (Fig. 6). Late Neoproterozoic felsic magmatism is scarce in Laurentia and Baltica (e.g. Nance et al., 2008 and references therein), suggesting that detritus in the Sierra Nevada Fm. was derived from Gondwanan (e.g. Chew et al., 2008) or peri-Gondwanan (e.g. Nance et al., 2008) sources in the Late Cambrian prior to metamorphism in the Early Ordovician.

Unfortunately, there are no interpretable palaeomagnetic data from Palaeozoic rocks of the Northern Andes. Palaeomagnetic data from Jurassic and Cretaceous strata suggest that the rocks of the Mérida Andes lack latitudinal displacement relative to the Guyana Shield (Castillo et al., 1991; Bayona et al., 2010), in contrast to the Sierra Nevada de Santa Marta and the Floresta Massif (Fig. 1) which may have moved northwards by $\sim 10^{\circ}$ since the Jurassic (Bayona et al., 2010). Miocene transpression led to the northeastern extrusion of the Maracaibo Block by approximately $290 \mathrm{~km}$ (Dewey and Pindell, 1985).

Insufficient data are available from Palaeozoic units in the pericratonic basins to establish reliable correlations with the metamorphic rocks of the Mérida Andes and the Santander Massif. The oldest known sedimentary sequences in the pericratonic Venezuelan Llanos Basin are Early Cambrian graben filling sedimentary rocks in the Espino Graben (Fig. 1; e.g. Feo-Codecido et al., 1984), which are unconformably overlain by Permian to Cretaceous sequences. New seismic data hints at an Ordovician fold and thrust belt in the Colombian Llanos Basin (e.g. Moreno-Lopez, 2012; Suárez Díaz and Solano, 2012), arising from early Palaeozoic compression which may have been contemporaneous with Barrovian metamorphism in the Mérida Andes and the Santander Massif. This suggests that the Llanos Basin, the Mérida Andes and the Santander Massif were simultaneously subjected to similar tectonic regimes.

Geochronological and isotopic analyses of basement blocks in the Santander Massif and the Mérida Andes are consistent with them being derived from Gondwanan sources, and these blocks have experienced very similar tectono-metamorphic histories (Fig. 14) since at least 500 Ma. Multiple accretionary episodes of allochthonous terranes are not required to explain any existing data obtained from rocks exposed in the Mérida Andes and the Santander Massif, and we recommend that the terms "Chibcha Terrane" and "Mérida Terrane" should no longer be used. This conclusion 
is similar to that reached by Spikings et al. (2014) for the Tahami and Chaucha Terranes of Colombia and Ecuador, who suggest that these are autochthonous or paraautochthonous sequences.

\section{Tectonic setting of the basement of the Santander Massif and the Merida Andes}

\subsection{Precambrian}

Our data demonstrate the presence of Precambrian protoliths with ages of $~ 1018.3$ Ma to $\sim 1008.6 \mathrm{Ma}$ (08VDL11; Fig. 8) although these ages alone can not be used to determine their tectonic setting. Anhedral orthopyroxene in orthogneiss 08VDL11 may indicate granulite facies conditions for the protolith (Spear et al., 1999). Rocks of similar age in the Garzon Massif, the Sierra Nevada de Santa Marta and the Serranía de San Lucas (Fig. 1) are frequently associated with granulite facies metamorphism, and are interpreted to have formed during the assembly of Rodinia (e.g. Ordoñez-Carmona et al., 2006; Ibanez-Mejia et al., 2011; Cuadros et al., 2014, and references therein). Rocks with crystallisation ages of $\sim 1 \mathrm{Ga}$ are exposed along large tracts of the western margin of South America (Sunsás belt; e.g. Fuck et al., 2008; Ramos, 2010), and have originated within a common tectonic setting

\subsection{Early Palaeozoic}

Upper amphibolite facies Barrovian metamorphism (Kovisars, 1971; García et al., 2005;

Castellanos et al., 2008) affected Cambrian (e.g. 08VDL05) and Precambrian sedimentary and igneous rocks in the Mérida Andes and Santander Massif. Geochronological analyses of migmatites and granitoids with syn-magmatic deformation suggest that peak metamorphic conditions were reached between $\sim 489$ and $\sim 472 \mathrm{Ma}$. An anatectic orthogneiss may date a point on the retrograde path at $\sim 454 \pm 10 \mathrm{Ma}$ (08VDL11), and isotropic granitoids with ages between $\sim 472$ and $448 \mathrm{Ma}$ crosscut the metamorphic foliation. The amphibolitic rocks are unconformably overlain at $\sim 453 \mathrm{Ma}$ by low grade, felsic metavolcanic rocks of the Mucuchachi Formation near Bailadores (08VDL15), which are interfingered with massive-sulphide mineralized metasedimentary rocks (e.g., Staargaard and Carlson, 2000). Volcanogenic massive sulphide mineralisation commonly forms in extensional settings related to magmatic arcs (e.g. Schandl and Gorton, 2002; Shanks and Thurston, 2012).

These relationships require (i) tectonic burial of Cambrian and Precambrian metasedimentary rocks to 5-8 kbar between $\sim 500$ and $\sim 472 \mathrm{Ma}$, implying that a period of crustal thickening and orogenesis occurred (Fig.15A), followed by (ii) exhumation during extension between $\sim 472$ and $\sim 453$ Ma (Fig. 15B), ending with basins forming over the amphibolite facies metamorphic rocks in the Bailadores 
region and in the Caparo Block (Caparo Fm.). Sufficient heating of the crust to produce granitic melts lasted from $\sim 500$ Ma until 4415 Ma.

The crustal blocks that host the Andes have undergone alternating periods of compression and extension since at least the Mesozoic over broad regions of the western margin of South America (Ramos, 2009; Spikings et al., 2014). Orogenic phases along active margins are generally considered to be a result of compression of crust that was previously thinned during trench roll-back (e.g. Dalziel, 1986; Collins, 2002; Collins and Richards, 2008; Kemp et al., 2009), and are caused by enhanced compressive coupling between subducting oceanic crust and the overriding continental crust (e.g. Gutscher, 2002; Ramos, 2009; Spikings and Simpson, 2014). Early Ordovician metamorphism is widespread along the western Gondwanan margin and is documented in the Marañon Complex of Peru ( 476 Ma; e.g. Chew et al., 2007; Mišković et al., 2009), the Famatinian Orogeny of Chile and Argentina (477-470 Ma; e.g. Büttner et al., 2005; Larrovere et al., 2011), and may have formed part of an Early Palaeozoic orogen that extended for more than $15000 \mathrm{~km}$ (Cawood, 2005). Parts of the Early Palaeozoic orogeny of western Gondwana may have been influenced by the docking of terranes (e.g. Cuyania and Paracas terranes; Rapela et al., 1998; Ramos, 2009), although several studies have shown that the extent of the Famatinian orogenic belt is far wider than the size of the Cuyania Terrane. Alternatively, Early Ordovician orogenesis in many parts of western Gondwana may be related to alternating cycles of slab advance and retreat, inducing compression and extension in the upper plate (e.g. Lucassen and Franz, 2005; Miller and Söllner, 2005; Larrovere et al., 2011). There is no evidence to support terrane collision outboard of the basement blocks of the Mérida Andes and the Santander Massif in the Ordovician, and we hypothesize that Barrovian metamorphism and subsequent extension in this region was not driven by the collision of allochthonous blocks.

Post-orogenic extension exhumed the amphibolite facies basement and opened a back-arc or intra arc basin by $\sim 453 \mathrm{Ma}$ (Fig. 15B). This basin is preserved in Venezuela as the lower part of the Mucuchachi Fm. (Fig. 14), which unconformably overlies the Sierra Nevada Suite (e.g. Staargaard and Carlson, 2000). The Caparo Fm. in the Caparo Block may have formed in a similar overall setting (e.g. Compañia Shell de Venezuela and Creole Petroleum Corporation, 1964), although it lacks volcanic rocks. The general paucity of Early Palaeozoic metasedimentary rocks (Fig. 14) suggests that this basin may have been short lived, and basin closure (Fig. 15C) may have been synchronous with the development of an unconformity spanning the interval $\sim 453 \mathrm{Ma}-\sim 445 \mathrm{Ma}$ in the Caparo Block (Caparo Fm. - El Horno Fm; Fig. 14). Magmatism lasted until 415 Ma although 
there is insufficient data to reliably document periods of extension and compression between $\sim 445$ Ma and $\sim 415$ Ma. Melting of the continental crust between $\sim 499$ and $\sim 415$ Ma to produce felsic magmatic rocks may have been facilitated by heat transfer from underplated mafic melts (Huppert and Sparks, 1988; Cochrane et al., 2014), and an active continental margin is a plausible setting for this process over a duration of $\sim 85 \mathrm{Ma}$.

\subsection{Permian}

The only Late Palaeozoic U-Pb data presently known in Venezuela are four $\mathrm{U}-\mathrm{Pb}$ ages obtained

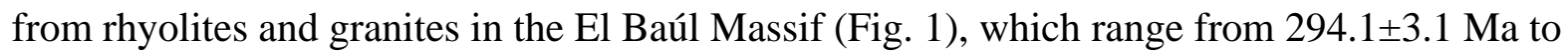

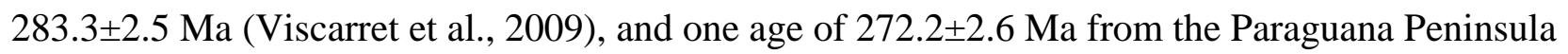
(this study). The El Baúl Massif (Fig. 1) may have been closer to the continental margin before northeastward movement of the Maracaibo Triangular Block during the Cainozoic (Pindell and Dewey, 1982), and it may have been transported eastwards along the southern Caribbean Plate boundary in the Cainozoic (e.g. van der Lelij et al., 2010). These translations would place the rocks of the El Baúl massif in a similar palinspastic position as the Permian rocks of the Sierra Nevada de Santa Marta and the Paraguana Peninsula. However, there are still insufficient data from the El Baúl massif and its surrounding region to further constrain its geological history.

Permian magmatism along the northwestern margin of Gondwana may have been coeval with sedimentation of the Diamante, Tiburón and Bocas formations in the Santander Massif, and the Sabaneta and Palmarito formations in the Mérida Andes (Fig. 14). Carboniferous to Permian sedimentary successions in the Mérida Andes have been interpreted to form part of a foreland basin (Laya and Tucker, 2012), which may have formed during the final stages of the Alleghanian Orogeny, culminating with the amalgamation of Pangaea by the Early Permian (Hatcher, 2002).

Cardona et al. (2010) suggest that the Permian magmatic rocks in the Sierra Nevada de Santa Marta (Fig. 1) were emplaced in a magmatic arc. The basement of the Paraguana Peninsula (Fig. 1; Diorite 08VDL64) may have been separated from the Sierra Nevada de Santa Marta during Cainozoic dextral displacement between the Caribbean and the South American plates (van der Lelij et al., 2010). Therefore, Permian felsic magmatism in Venezuela may also be related to subduction of oceanic crust beneath western Pangaea (Cardona et al., 2010; Laya and Tucker, 2012).

\subsection{Mesozoic}


There was sparse felsic magmatism between $\sim 250$ and $225 \mathrm{Ma}$ in the Santander Massif and the Mérida Andes, and the geochemical data are not diagnostic of any particular tectonic setting (Fig. 11). A maximum stratigraphic age of $202 \mathrm{Ma}$ for the La Quinta formation (Mérida Andes; 08VDL18) and a minimum stratigraphic age of 250 Ma for the Bocas Fm. (Santander Massif; 10VDL58) suggest that Triassic basins may be absent from both of these regions (Fig. 14). In contrast, Early Triassic basins are documented in the Central Cordillera of Colombia and in Ecuador, which were coeval with numerous mafic intrusions, crustal anatexis and foliated S-type granitoids (e.g., Jaillard et al., 1995; Villagómez et al., 2011; Cochrane et al., 2014; Spikings et al., 2014). These formed during extension and rifting along the Pacific margin during the disassembly of Pangaea between $240 \mathrm{Ma}$ and $216 \mathrm{Ma}$ (Cochrane et al., 2014; Spikings et al., 2014). We propose that magmatism between 250 and 196 Ma in the Mérida Andes and the Santander Massif formed in a continental arc or in a back arc. Early Triassic back-arc extension along the western margin of Pangaea did not affect the rocks of the Mérida Andes and the Santander Massif, perhaps because they were too distant from the locus of extension. The magmatic rocks with ages spanning the interval 250 - 225 Ma from the Serranía del Perijá and Toas Island have similar geochemistry to the latest Triassic to Earliest Jurassic granitoids in the Santander Massif, and we propose that they may also be related to subduction of oceanic crust of the Pacific Ocean.

Magmatism at 213 - 211 Ma produced one large peraluminous pluton in the Mérida Andes (Fig. 2), which was followed by the intrusion of pegmatite dikes and migmatites at 209 Ma in the Santander Massif (Fig. 14). Subsequently, the locus of magmatism migrated westward to produce voluminous shallow batholiths in the Santander Massif. Extension after $202 \mathrm{Ma}$ is documented in the Mérida Andes and the Santander Massif by the syn-rift La Quinta, Jordán and Girón Formations (Fig. 14; Maze, 1984; Kammer and Sánchez, 2006).

Magmatism and extension between $\sim 213$ and $\sim 196$ Ma in the Northern Andes was coeval with graben development and red bed deposition in many parts of the Andean range (e.g. Ramos, 2009). The oldest reliable date for Jurassic arc magmatism in the Central Cordillera of Colombia (Fig. 1) is $\sim 189 \mathrm{Ma}$ (zircon U-Pb; Bustamante et al., 2010), and we propose that magmatism spanning the interval 213 - 196 Ma in the Mérida Andes and the Santander Massif was related to a continental active margin. The arc axis may have migrated westward between $\sim 205 \mathrm{Ma}$ and $\sim 189 \mathrm{Ma}$ during extension, as a result of slab roll-back (Spikings et al., 2014). 
The timing of rifting which led to complete separation of North and South America and the formation of the oceanic crust in the Caribbean Sea may not be constrained by our data, although previous work suggests that it may have occurred in several stages from the Triassic to Middle Jurassic. (e.g. Bartok, 1993; Beutel, 2009). Although the sedimentary features and spatial distribution of the La Quinta Fm. are consistent with formation in grabens (Maze, 1984; Gonzales de Juana et al., 1980; Bartok, 1993; Odremán and Useche, 1997), these may record several reactivation episodes throughout the Jurassic (Maze, 1984). Rhyodacite 08VDL18 ( 202 Ma; Table 1) located at the base of the La Quinta Fm. provides evidence for the earliest Mesozoic rifting in the Mérida Andes. This is indistinguishable from the timing of the Central Atlantic Magmatic Province at $201 \mathrm{Ma}$ (e.g. Marzoli et al., 1999), which formed during the initial stages of rifting of the Central Atlantic Ocean. However, the Central Atlantic Magmatic Province mainly consists of tholeiitic basalts, and no felsic calc alkaline rocks have been identified (e.g. Menzies et al., 2002 and references therein). Consequently, we consider the La Quinta rhyodacite to be related to an active margin in an extensional regime rather than a western remnant of the Central Atlantic Magmatic Province.

\section{Tectonic model}

Early Palaeozoic rocks in the Northern Andes record continental arc magmatism between 499 and $\sim 415 \mathrm{Ma}$, orogenesis between $\sim 500$ and $\sim 473 \mathrm{Ma}$ (Fig. 15a, Fig. 16), followed by intra-arc or backarc extension and basin formation at $\sim 453 \mathrm{Ma}$ (Fig. 15b). The arc rocks are coeval with the Famatinian arc (e.g. Bahlburg et al., 2009 and references therein) and arc-related intrusions in the Eastern Cordillera of Peru, and probably represent the northern extent of the same arc-subduction system (Fig. 16).

Existing plate tectonic models for northwestern Gondwana show the rift to drift transition which opened the Rheic Ocean occurred between $\sim 505$ and $\sim 480 \mathrm{Ma}$, and this separated several periGondwanan terranes from Gondwana (Avalonia, Carolinia and Ganderia; e.g. Murphy et al., 2004; Linnemann et al., 2008; Nance et al., 2010; van Staal et al., 2012 and references therein). However, autochthonous, Early Palaeozoic rocks of the Northern Andes record orogenesis between $~ 505$ and $\sim 472 \mathrm{Ma}$, which is not consistent with a rift to passive margin transition. Therefore, it appears unlikely that the rifted margin of the Rheic Ocean was outboard of the Mérida Andes and the Santander Massif between $\sim 500$ and $\sim 42$ Ma (Fig. 16a). The Palaeozoic Espino Graben (FeoCodecido et al., 1984) lies to the East of the Mérida Andes (Fig. 1) where Precambrian and Palaeozoic rocks are truncated by the Caribbean Plate and the Atlantic Ocean. We interpret this 
graben to represent the westernmost extension of the rift which resulted in the opening of the Rheic Ocean between $\sim 500$ and $\sim 480 \mathrm{Ma}$ (Fig. 16a).

Several crustal fragments may have been adjacent to northwestern Gondwana during the Palaeozoic, including rocks presently found in Guatemala (Maya Block; e.g. Ratschbacher et al., 2009; Estrada-Carmona et al., 2012; Solari et al., 2013 and references therein), Belize (Maya Block; e.g. Martens et al., 2010) and Mexico (Acatlán Complex; e.g. Keppie, 2004; Keppie et al., 2008; Vega-Granillo et al., 2007, 2009). No consensus exists on the Early Palaeozoic tectonic setting of any of these terranes, which are considered to record either (i) Ordovician to Silurian rifting and passive margin development on the southern margin of the Rheic Ocean (e.g. Estrada-Carmona et al., 2012; Keppie et al., 2008, 2012b), or (ii) Ordovician orogenesis and Ordovician to Silurian continental arc magmatism (e.g. Ratschbacher et al., 2009; Vega-Granillo et al., 2009; Solari et al., 2013). These strongly contrasting interpretations have been used to suggest that either the Rheic Ocean opened along the western margin of Gondwana, with its southern extent in front of present day Peru (e.g. Pollock et al., 2009; van Staal et al., 2012), or opened >2700 km further along-strike to the northeast, possibly outboard of Eastern Venezuela (Fig. 16a; this study). This controversy is a problem for any Ordovician tectonic reconstruction of Gondwana and Avalonia, and consequently for Silurian tectonic reconstructions of Baltica and eastern Laurentia.

The new evidence presented in this paper contrasts with some interpretations of the geology of southern Mexico (Acatlán Complex; e.g., Keppie et al., 2008), which may have been a part of northwestern Gondwana from $\sim 1$ Ga until its separation at 220 Ma (e.g. Noble et al., 1997; Keppie and Ortega-Gutierrez, 1999; Ruiz et al., 1999; Keppie, 2004; Cochrane et al., 2014; Spikings et al., 2014). The Acatlán Complex hosts continental bimodal magmatic rocks spanning the interval $\sim 470$ - $440 \mathrm{Ma}$ (e.g. Keppie et al., 2012b and references therein), which are interpreted to record a rift to passive margin transition on the southern margin of the Rheic Ocean between 500 and 440 Ma, (Keppie et al., 2008). However, the hypothesis of passive margin development during this period is challenged by evidence of high pressure, low temperature metamorphism in the Acatlán Complex at 478 Ma, which is diagnostic of active margins but not of passive margin development (e.g. VegaGranillo et al., 2009 and references therein). Furthermore, although the bimodal magmatic assemblage suggests extension, this may be related to a continental back-arc environment (e.g. Shinjo and Kato, 2000; Nivia et al., 2006; Helbig et al., 2012b). Finally, crystallisation of MORBlike tholeiitic rocks in the Acatlán Complex in the interval $470-\sim 440$ Ma (e.g. Keppie et al., 
$2012 \mathrm{~b}$ and references therein) post-dates the drift stage of the Rheic Ocean (505-480 Ma; e.g. Linnemann et al., 2008; Nance et al., 2010; van Staal et al., 2012) by at least 10 - 40 Ma.

We hypothesize that high pressure metamorphism at 478 Ma documented in the Acatlán Complex (e.g. Vega-Granillo et al., 2009) and bimodal magmatism between $470 \pm 10 \mathrm{Ma}$ and $442 \pm 1 \mathrm{Ma}$ (e.g. Keppie et al., 2012b and references therein) may be related to (i) compression at $\sim 478$ Ma followed by (ii) periods of extension between $\sim 470$ and $\sim 440 \mathrm{Ma}$ in an active margin along western Gondwana. This hypothesis is consistent with the calc-alkaline geochemistry and arc signature of granitoids in the Acatlán Complex which intruded between $488 \mathrm{Ma}$ and $442 \mathrm{Ma}$ (e.g. Miller et al., 2007; Keppie et al., 2010, 2012a) and their association with tholeiitic basalts which formed between $\sim 470 \mathrm{Ma}$ and $\sim 40 \mathrm{Ma}$ (Keppie et al., 2012b).

The Acatlán Complex and other fragments of Central America were separated from Gondwana during the disassembly of Pangaea (e.g. Keppie and Ortega-Gutierrez, 1999) during the Triassic (e.g. Cochrane et al., 2014; Spikings et al., 2014). Recent suggestions for its position prior to Pangaea breakup include a position outboard of the Mérida Andes and Santander Massif (see Helbig et al., 2012a). Arc magmatism occurred in the intervals $\sim 500-\sim 415$ Ma and $\sim 250-\sim 195$ Ma in autochthonous rocks of the Mérida Andes and the Santander Massif, and the presence of large portions of the basement of southern Mexico outboard of the pre-Cainozoic basement of Colombia and Venezuela (Fig.1; e.g. Keppie, 2004) implies an arc to (Pacific) trench distance in excess of $1000 \mathrm{~km}$ (Fig. 17). We suggest that the Acatlán Complex and other Central American terranes may have been along-strike either southward (Fig. 17) or northwestward from the basement rocks of the Santander Massif and the Mérida Andes during the Palaeozoic (e.g. Helbig et al., 2012a; Keppie and Keppie, 2012). A potential position for the Acatlán Complex prior to its separation from Gondwana may be outboard of the Triassic magmatic belt in Ecuador and southerncentral Colombia (Fig. 16a-e, Fig. 17), where (i) Early Palaeozoic igneous or metamorphic basement is not reported, (ii) the Precambrian basement may be much closer to the pre-Cainozoic margin of South America than in Colombia or Venezuela (Fig. 1), and (iii) Triassic basement rocks record dextral shearing during removal of a conjugate margin at $240-216 \mathrm{Ma}$ (e.g. Noble et al., 1997, Cochrane et al., 2014; Spikings et al., 2014). This hypothesis is supported by data suggesting that the Acatlán Complex was on the western margin of Pangaea at $250 \mathrm{Ma}$, prior to Pangaea breakup (e.g. Helbig et al., 2012a, b; Kirsch et al., 2012). 
There may have been a lack of magmatism in northwest South America between 415 Ma and 300 Ma, as suggested by our data (Table 1) and by detrital zircon U-Pb data (Horton et al., 2010) within the study areas. Similarly, Devonian igneous and high grade metamorphic rocks are not documented over an along-strike distance of $>5000 \mathrm{~km}$ on the western margin of Gondwana (Bahlburg et al., 2009, Reitsma, 2012), with the exception of the Achala Batholith in Argentina (379 Ma - 369 Ma; e.g. Dahlquist et al., 2012). The low volume of Devonian magmatism has led to suggestions that the margin became passive at the end of the Silurian (Fig. 16C; e.g. Bahlburg et al., 2009). It is not clear how a convergent margin could become passive along most of the western margin of Gondwana. Subduction termination by large scale terrane accretion or removal of the arc by faulting are not documented. Fauna and flora in autochthonous Devonian rocks in the Santander Massif, the Sierra de Perijá and Bolivia show affinities to both Gondwana and Laurentia (e.g. Berry et al., 2000; Janvier and Villarroel, 2000; Troth et al., 2011), which supports proximity between Laurentia and Gondwana in the Devonian (Fig. 16d; e.g. McKerrow et al., 2000; Torsvik and Cocks, 2004). However, there is no evidence for deformation resulting from collision between Gondwana and Laurentia in the Devonian.

Known Devonian tectonic rearrangements which affected Gondwana and Laurentia include, (i) closure of the northern Iapetus Ocean, resulting in the formation of Laurussia by 430-420 Ma (Fig. 16c; e.g. Cocks and Torsvik, 2002), followed by (ii) the onset of subduction of Rheic Ocean crust beneath the Appalachian margin at $410 \mathrm{Ma}$ (Fig. 16d; e.g. Nance et al., 2010), and (iii) changes in directions of rotation of Gondwana from clockwise at $\sim 420$ Ma to counter clockwise at $\sim 400 \mathrm{Ma}$ (Torsvik et al., 2012). We hypothesize that these changes resulted in either highly oblique, amagmatic subduction, or cessation of subduction beneath the western margin of South America in the interval $\sim 415-\sim 350 \mathrm{Ma}$.

Late Palaeozoic arc magmatism started at $\sim 335 \mathrm{Ma}$ in the Eastern Cordillera of Peru (Mišković et al., 2009), at 293 Ma in the Sierra Nevada de Santa Marta (Fig. 16e; Cardona et al., 2010), and perhaps in the El Baúl Massif at 294 Ma (Viscarret et al., 2009). Minor arc magmatism is recorded between 250 and $225 \mathrm{Ma}$ in Toas Island, the Perijá Andes (Fig. 1), the Santander Massif and in the Mérida Andes, where it was followed by more voluminous intrusions at $213 \mathrm{Ma}$. Slab roll back occurred during arc magmatism between $202 \mathrm{Ma}$ and $\sim 196 \mathrm{Ma}$ (Fig. 17), was coeval with the formation of back-arc basins, and was accompanied by the migration of the arc axis to the west into the Central Cordillera of Colombia at 189 Ma (Spikings et al., 2014). 


\section{Conclusions}

1) There is no evidence for the existence of allochthonous terranes in the Merida Andes or the Santander Massif, and we suggest that the Merida Terrane and the Chibcha Terrane, as they were originally defined, do not exist.

2) The Santander Massif and the Mérida Andes host the remnants of an Early Palaeozoic active margin which lasted from $>\sim 500 \mathrm{Ma}$ to $<\sim 415 \mathrm{Ma}$

3) The onset of active margin magmatism was followed shortly by Barrovian metamorphism related to compressional orogenesis associated with trench advance. Migmatites and syn-deformational granitoids record peak to retrograde conditions between $\sim 477$ and $\sim 454$ Ma.

4) Trench roll back resulted in the formation of a back-arc or intra-arc basin over the metamorphic basement at $\sim 453 \mathrm{Ma}$. The duration of extension is uncertain but the highly discontinuous sedimentary record suggests that the depocenters closed rapidly, or are not preserved.

5) Cessation of arc magmatism at $415 \mathrm{Ma}$ along most of the western Gondwanan margin may have resulted from amagmatic subduction or cessation of subduction during changes in rotation direction of Gondwana (Fig. 16).

6) Peri-Gondwanan terranes involved in the Caledonian and Appalachian orogenies (e.g. Ganderia, Carolinia and Avalonia, Fig. 16a) may have originated from the region to the east of the Palaeozoic orogenic belt exposed in the Mérida Andes, rather than originating outboard of this region. These relationships constrain the Early Palaeozoic western limit of the Rheic Ocean, and the extent of preserved autochthonous Early Palaeozoic continental arc rocks within Gondwana.

7) There are no reliable published constraints on late Palaeozoic deformations in the Merida Andes or the Santander Massif during the amalgamation of Pangaea, perhaps because these regions were too far from the collision zone (Fig. 17). However, it has recently been proposed that Permian sedimentary sequences in the Merida Andes were deposited in a foreland basin (e.g. Laya and Tucker, 2012).

8) Late Palaeozoic to Early Jurassic arc magmatism resulted from subduction of the Pacific Ocean beneath western Pangaea (Fig. 17). Voluminous igneous activity between 205 Ma and $~ 196$ Ma in an extensional regime marks the beginning of the Andean subduction cycle in the Northern Andes. 


\section{Acknowledgements}

The authors are grateful to Prof. Tabata Hoeger, Daniela Tazzo and Maria Carolina Maninat from ULA Mérida for field assistance in the Mérida Andes, and to Prof. Mauricio Bermúdez from UCV Caracas for logistical support. Field work and logistics in Colombia were greatly facilitated by the generous assistance of Ecopetrol. Luigi Solari and an anomynous reviewer are thanked for their constructive reviews which helped to improve this manuscript. This project was funded by the Swiss National Science Foundation fund 200021_129497, which was awarded to RS.

\section{Supplementary items:}

Figure 1: U-Pb Concordia diagrams for rocks from Venezuela, Figure 2: Concordia diagrams for rocks from the Santander Massif, Table 3: geochemical data, Table 4: U-Pb data and Table 5: detrital zircon data available from the online version of the journal at: yyyyyyyy

\section{References}

Aleman, A., and Ramos, V.A., 2000, The Northern Andes, in Cordani, U.G., Milani, E.J., Thomaz, A., and Campos, D.A. eds., Tectonic Evolution of South America, Rio de Janeiro, Brazil, p. 453-480.

Amante, C., and Eakins, B.W., 2008, ETOPO1 1 arc-minute global relief model: procedures, data sources and analysis: National Geophysical Data Center, NESDIS, NOAA, US Department of Commerce, Boulder, CO.

Astini, R.A., Benedetto, J.L., and Vaccari, N.E., 1995, The early Paleozoic evolution of the Argentine Precordillera as a Laurentian rifted, drifted, and collided terrane: A geodynamic model: Geological Society of America Bulletin, v. 107, no. 3, p. 253-273.

Audemard, F.E., and Audemard, F.A., 2002, Structure of the Mérida Andes, Venezuela: relations with the South America-Caribbean geodynamic interaction: Tectonophysics, v. 345, no. 1-4, p. 299-327.

Bahlburg, H., Vervoort, J.D., Du Frane, S.A., Bock, B., Augustsson, C., and Reimann, C., 2009, Timing of crust formation and recycling in accretionary orogens: Insights learned from the western margin of South America: Earth-Science Reviews, v. 97, no. 1-4, p. 215-241.

Barrett, P.M., Butler, R.J., Moore-Fay, S.C., Novas, F.E., Moody, J.M., Clark, J.M., and Sänchez-Villagra, M.R., 2008, Dinosaur remains from the La Quinta Formation (Lower or Middle Jurassic) of the Venezuelan Andes: Paläontologische Zeitschrift, v. 82, no. 2, p. 163-177.

Bartok, P., 1993, Prebreakup geology of the Gulf of Mexico-Caribbean: Its relation to Triassic and Jurassic rift systems of the region: Tectonics, v. 12, no. 2, p. 441-459.

Bass, M., and Shagam, R., 1959, Edades Rb-Sr de las rocas cristalinas de Los Andes merideños, Venezuela, in Caracas, Venezuela.

Bayona, G., Jiménez, G., Silva, C., Cardona, A., Montes, C., Roncancio, J., and Cordani, U.G., 2010, Paleomagnetic data and K-Ar ages from Mesozoic units of the Santa Marta massif: A preliminary interpretation for block rotation and translations: Journal of South American Earth Sciences, v. 29, no. 4 , p. $817-831$. 
Bellizzia, A., and Pimentel, N., 1994, Terreno Mérida: Un cinturón alóctono herciniano en la Cordillera de Los Andes de Venezuela, in V Simposio Bolivariano Exploracion Petrolero, Caracas, Venezuela, p. 271-290.

Bermúdez, M.A., van der Beek, P., and Bernet, M., 2011, Asynchronous Miocene-Pliocene exhumation of the central Venezuelan Andes: Geology, v. 39, no. 2, p. 139-142.

Berry, C.M., Morel, E., Mojica, J., and Villaroel, C., 2000, Devonian plants from Colombia, with discussion of their geological and palaeogeographical context: Geological Magazine, v. 137, no. 3, p. 257-268.

Beutel, E.K., 2009. Magmatic rifting of Pangaea linked to onset of South America plate motion. Tectonophysics 468, 149-157.

Boinet, T., Babin, C., Bourgois, J., Broutin, J., Lardeux, H., Pons, D., and Racheboeuf, P., 1986, Les grandes étapes de l'évolution paléozoïque du massif de Santander (Andes de Colombie): signification de la discordance du Dévonien moyen: Comptes rendus de l'Académie des sciences. Série 2, Mécanique, Physique, Chimie, Sciences de l'univers, Sciences de la Terre, v. 303, no. 8, p. 707-712.

Boinet, T., Bourgois, J., Bellon, H., and Toussaint, J.F., 1985, Age et répartition du magmatisme Prémésozoïque des Andes de Colombie: Comptes-rendus des séances de l'Académie des sciences. Série 2, Mécanique-physique, chimie, sciences de l'univers, sciences de la terre, v. 300, no. 10, p. 445-450.

Bryan, S.E., Riley, T.R., Jerram, D.A., Stephens, C.J., Leat, P.T., 2002. Silicic volcanism: an undervalued component of large igneous provinces and volcanic rifted margins. Geological Society of America Special Papers 362, 97-118.

Burkley, L.A., 1976, Geochronology of the central Venezuelan Andes [PhD Thesis, Case Western Reserve University, Cleveland, Ohio]: $150 \mathrm{p}$.

Bustamante, C., Cardona, A., Bayona, G., Mora, A., Valencia, V., Gehrels, G., and Vervoort, J., 2010, U-Pb LA-ICP-MS geochronology and regional correlation of Middle Jurassic intrusive rocks from the Garzón Massif, Upper Magdalena Valley and Central Cordillera, Southern Colombia.: Boletin de Geología, v. 32, no. 2, p. 93-109.

Büttner, S.H., Glodny, J., Lucassen, F., Wemmer, K., Erdmann, S., Handler, R., and Franz, G., 2005, Ordovician metamorphism and plutonism in the Sierra de Quilmes metamorphic complex: Implications for the tectonic setting of the northern Sierras Pampeanas (NW Argentina): Lithos, v. 83, no. 1, p. 143-181.

Cáceres, C., Cediel, F., and Etayo, F., 2003, Maps of sedimentary facies distribution and tectonic setting of Colombia through the Proterozoic and Phanerozoic: Ingeominas, Bogota, Colombia.

Cardona, A., Valencia, V., Garzón, A., Montes, C., Ojeda, G., Ruiz, J., and Weber, M., 2010, Permian to Triassic I to S-type magmatic switch in the northeast Sierra Nevada de Santa Marta and adjacent regions, Colombian Caribbean: Tectonic setting and implications within Pangea paleogeography: Journal of South American Earth Sciences, v. 29, no. 4, p. 772-783.

Carlson, G.G., 1977, Geology of the Bailadores, Venezuela, massive sulfide deposit: Economic Geology, v. 72 , no. 6 , p. $1131-1141$.

Case, J.E., Shagam, R., and Giegengack, R.F., 1990, Geology of the northern Andes: An overview, in Dengo, G. and Case, J.E. eds., The Caribbean region, The Geology of North America, Geological Society of America, Boulder, Colorado, p. 177-200. 
Castellanos, Ó.M.A., Ríos R, C.A., and Takasu, A., 2008, A new approach on the tectonometamorphic mechanisms associated with PT paths of the Barrovian-type Silgará Formation at the Central Santander Massif, Colombian Andes: Earth Sciences Research Journal, v. 12, no. 2, p. 125-155.

Castillo, J., Gose, W.A., and Perarnau, A., 1991, Paleomagnetic results from Mesozoic strata in the Mérida Andes, Venezuela: Journal of Geophysical Research, v. 96, no. B4, p. 6011-6022.

Cawood, P.A., 2005, Terra Australis Orogen: Rodinia breakup and development of the Pacific and Iapetus margins of Gondwana during the Neoproterozoic and Paleozoic: Earth-Science Reviews, v. 69, no. 3-4, p. 249-279.

Chappell, B.W., and White, A.J.R., 1974, Two contrasting granite types: Pacific Geology, v. 8, no. 2, p. 173174.

Chew, D.M., Magna, T., Kirkland, C.L., Miskovic, A., Cardona, A., Spikings, R., and Schaltegger, U., 2008, Detrital zircon fingerprint of the Proto-Andes: Evidence for a Neoproterozoic active margin?: Precambrian Research, v. 167, no. 1-2, p. 186-200.

Chew, D., Schaltegger, U., Kosler, J., Whitehouse, M.J., Gutjahr, M., Spikings, R.A., and Miskovic, A., 2007, U-Pb geochronologic evidence for the evolution of the Gondwanan margin of the north-central Andes: Geological Society of America Bulletin, v. 119, no. 5-6, p. 697-711.

Chiaradia, M., Müntener, O., and Beate, B., 2011, Enriched Basaltic Andesites from Mid-crustal Fractional Crystallization, Recharge, and Assimilation (Pilavo Volcano, Western Cordillera of Ecuador): Journal of Petrology, v. 52, no. 6, p. 1107-1141.

Cochrane, R., 2013, U-Pb thermochronology, geochronology and geochemistry of NW South America: Rift to drift transition, active margin dynamics and implications for the volume balance of continents [PhD Thesis]: University of Geneva, Switzerland, 202 p.

Cochrane, R., Spikings, R., Gerdes, A., Ulianov, A., Mora, A., Villagómez, D., Putlitz, B., Chiaradia, M., 2014, Permo-Triassic anatexis, continental rifting and the disassembly of western Pangaea: Lithos, v.190-191, p. 383-402

Cocks, L.R.M., and Torsvik, T.H., 2002, Earth geography from 500 to 400 million years ago: a faunal and palaeomagnetic review: Journal of the Geological Society, v. 159, no. 6, p. 631-644.

Cocks, L.R.M., and Torsvik, T.H., 2006, European geography in a global context from the Vendian to the end of the Palaeozoic: Geological Society of London, Memoirs, v. 32, p. 83-95.

Colletta, B., Roure, F., De Toni, B., Loureiro, D., Passalacqua, H., and Gou, Y., 1997, Tectonic inheritance, crustal architecture, and contrasting structural styles in the Venezuela Andes: Tectonics, v. 16, no. 5, p. 777-794.

Collins, W.J., 2002, Hot orogens, tectonic switching, and creation of continental crust: Geology, v. 30, no. 6, p. 535.

Collins, W.J., and Richards, S.W., 2008, Geodynamic significance of S-type granites in circum-Pacific orogens: Geology, v. 36, no. 7, p. 559-562.

Compañia Shell de Venezuela, and Creole Petroleum Corporation, 1964, Paleozoic rocks of Merida Andes, Venezuela: AAPG Bulletin, v. 48, no. 1, p. 70-84.

Cordani, U.G., Cardona, A., Jimenez, D.M., Liu, D., and Nutman, A.P., 2005, Geochronology of Proterozoic basement inliers in the Colombian Andes: Tectonic history of remnants of a fragmented Grenville belt: Geological Society, London, Special Publications, v. 246, no. 1, p. 329-346. 
Cordani, U.G., Garcia Jarpa, R., Pimentel, N., and Etchart, H., 1985, Comentarios sobre dataciones geocronologicas en la region de los Andes Centrales, in VI Congreso Geologico Venezolano, p. $1571-1585$.

Cuadros, F.A., Botelho, N.F., Ordóñez-Carmona, O., Matteini, M., 2014. Mesoproterozoic crust in the San Lucas Range (Colombia): An insight into the crustal evolution of the northern Andes. Precambrian Research 245, 186-206.

Dahlquist, J.A., Pankhurst, R.J., Gaschnig, R.M., Rapela, C.W., Casquet, C., Alasino, P.H., Galindo, C., and Baldo, E.G., 2012, Hf and Nd isotopes in Early Ordovician to Early Carboniferous granites as monitors of crustal growth in the Proto-Andean margin of Gondwana: Gondwana Research,.

Dalziel, I.W.D., 1986, Collision and Cordilleran orogenesis: an Andean perspective: Geological Society, London, Special Publications, v. 19, no. 1, p. 389-404.

Dewey, J., and Pindell, J., 1985, Neogene Block Tectonics of Eastern Turkey and Northern South America: Continental Applications of the Finite Difference Method: Tectonics, v. 4, no. 1, p. 71-83.

Dörr, W., Grösser, J.R., Rodriguez, G.I., and Kramm, U., 1995, Zircon U-Pb age of the Paramo Rico tonalite-granodiorite, Santander Massif (Cordillera Oriental, Colombia) and its geotectonic significance: Journal of South American Earth Sciences, v. 8, no. 2, p. 187-194.

Estrada-Carmona, J., Weber, B., Martens, U., and López-Martínez, M., 2012, Petrogenesis of Ordovician magmatic rocks in the southern Chiapas Massif Complex: relations with the early Palaeozoic magmatic belts of northwestern Gondwana: International Geology Review, v. 54, no. 16, p. 1-26.

Etchart, H., and Cordani, U.G., 1981, Metodos isotopicos en los Andes Venezolanos, in Santo Domingo, Dominican Republic.

Feo-Codecido, G., Smith Jr, F.D., Aboud, N., and Di Giacomo, E., 1984, Basement and Paleozoic rocks of the Venezuelan Llanos basins: Geological Society of America, Memoir, v. 162, p. 173-187.

Forero Suarez, A., 1990, The basement of the Eastern Cordillera, Colombia: An allochthonous terrane in northwestern South America: Journal of South American Earth Sciences, v. 3, no. 2, p. 141-151.

Fuck, R.A., Brito Neves, B.B., and Schobbenhaus, C., 2008, Rodinia descendants in South America: Precambrian Research, v. 160, no. 1, p. 108-126.

García, C., Ríos, C., and Castellanos, Ó.M.A., 2005, Medium-pressure metamorphism of the Silgará Formation in the central Santander Massif, Eastern Cordillera, Colombian Andes: constraints for a collision model: Boletín de Geología, Universidad Industrial de Santander, v. 27, no. 2, p. 43-68.

Goldsmith, R., Marvin, R.F., and Mehnert, H.H., 1971, Radiometric ages in the Santander Massif, eastern Cordillera, Colombian Andes: United States Geological Survey Professional Paper, v. 750, no. D, p. $44-49$.

Gómez, J., Nivia, A., Montes, N.E., Jiménez, D.M., Sepúlveda, J., Gaona, T., Osorio, J., Diederix, H., Mora, M., and Velásquez, M., 2007, Atlas geológico de Colombia 1:500’000: Instituto Colombiano de Geología y Minería Geological Map.

Gonzales de Juana, C., de Arozena, J.M.., and Cadillat, X.P., 1980, Geología de Venezuela y de sus Cuencas Petrolíferas: Foninves, Caracas.

Gradstein, F.M., Ogg, J.G., Schmitz, M., and Ogg, G., 2012, The Geologic Time Scale 2012: Elsevier, Boston, USA. 
Grauch, R.I., 1972, Preliminary report of a Late (?) Paleozoic metamorphic event in the Venezuelan Andes: Geological Society of America Memoir, v. 132, p. 465-473.

Gutiérrez-Marco, J.C., Goldman, D., Reyes-Abril, J., and Gómez, J., 2011, A preliminary study of some Sandbian (upper Ordovician) graptolites from Venzuela (J. C. Gutiérrez-Marco, I. Rábano, \& D. García-Bellido, Eds.): Ordovician of the World,, p. 199-206.

Gutscher, M.A., 2002, Andean subduction styles and their effect on thermal structure and interplate coupling: Journal of South American Earth Sciences, v. 15, no. 1, p. 3-10.

Hackley, P.C., Urbani, F., Karlsen, A.W., and Garrity, P., 2005, Geologic Shaded Relief Map of Venezuela: Open-file report, USGS,

Haq, B.U., and Schutter, S.R., 2008, A chronology of Paleozoic sea-level changes: Science, v. 322, no. 5898, p. 64-68.

Hatcher, R.D., 2002, Alleghanian (Appalachian) orogeny, a product of zipper tectonics: Rotational transpressive continent-continent collision and closing of ancient oceans along irregular margins: Geological Society of America Special Paper, , no. 364, p. 199-208.

Helbig, M., Keppie, J.D., Murphy, J.B., and Solari, L.A., 2012a, Exotic rifted passive margin of a back-arc basin off western Pangea: geochemical evidence from the Early Mesozoic Ayú Complex, southern Mexico: International Geology Review, , no. ahead-of-print, p. 1-19.

Helbig, M., Keppie, J.D., Murphy, J.B., and Solari, L., 2012b, U-Pb geochronological constraints on the Triassic-Jurassic Ayú Complex southern Mexico: Derivation from the western margin of Pangea-A: Gondwana Research,.

Holdaway, M.J., 1971, Stability of andalusite and the aluminum silicate phase diagram: American journal of science, v. 271, no. 2, p. 97-131.

Hoorn, C., Guerrero, J., Sarmiento, G.A., and Lorente, M.A., 1995, Andean tectonics as a cause for changing drainage patterns in Miocene northern South America: Geology, v. 23, no. 3, p. 237-240.

Horton, B.K., Saylor, J.E., Nie, J., Mora, A., Parra, M., Reyes-Harker, A., and Stockli, D.F., 2010, Linking sedimentation in the northern Andes to basement configuration, Mesozoic extension, and Cenozoic shortening: Evidence from detrital zircon U-Pb ages, Eastern Cordillera, Colombia: Geological Society of America Bulletin, v. 122, no. 9-10, p. 1423-1442.

Huppert, H.E., and Sparks, R.S.J., 1988, The generation of granitic magmas by intrusion of basalt into continental crust: Journal of Petrology, v. 29, no. 3, p. 599-624.

Ibanez-Mejia, M., Ruiz, J., Valencia, V.A., Cardona, A., Gehrels, G.E., and Mora, A.R., 2011, The Putumayo Orogen of Amazonia and its implications for Rodinia reconstructions: New U-Pb geochronological insights into the Proterozoic tectonic evolution of northwestern South America: Precambrian Research, v. 191, no. 1, p. 58-77.

Jackson, S., 2008, LAMTRACE data reduction software for LA-ICP-MS: Laser Ablation ICP-MS in the Earth Sciences: Current Practices and Outstanding Issues. Mineralogical Association of Canada, Short Course Series, v. 40, p. 305-307.

Jaillard, E., Sempere, T., Soler, P., Carlier, G., and Marocco, R., 1995, The role of Tethys in the evolution of the northern Andes between Late Permian and Late Eocene times (A. E. M. Naim, Ed.): New York.

Janvier, P., and Villarroel, C., 2000, Devonian vertebrates from Colombia: Palaeontology, v. 43, no. 4, p. 729-763. 
Kammer, A., and Sánchez, J., 2006, Early Jurassic rift structures associated with the Soapaga and Boyaca faults of the Eastern Cordillera, Colombia: Sedimentological inferences and regional implications: Journal of South American Earth Sciences, v. 21, no. 4, p. 412-422.

Kemp, A.I.S., Hawkesworth, C.J., Collins, W.J., Gray, C.M., and Blevin, P.L., 2009, Isotopic evidence for rapid continental growth in an extensional accretionary orogen: The Tasmanides, eastern Australia: Earth and Planetary Science Letters, v. 284, no. 3, p. 455-466.

Keppie, J.D., 2004, Terranes of Mexico revisited: A 1.3 billion year odyssey: International Geology Review, v. 46 , no. 9 , p. $765-794$.

Keppie, J.D., Dostal, J., Miller, B.V., Ramos-Arias, M.A., Morales-Gámez, M., Nance, R.D., Murphy, J.B., Ortega-Rivera, A., Lee, J.W.K., and Housh, T., 2008, Ordovician-earliest Silurian rift tholeiites in the Acatlán Complex, southern Mexico: Evidence of rifting on the southern margin of the Rheic Ocean: Tectonophysics, v. 461, no. 1-4, p. 130-156.

Keppie, J.D., Nance, R.D., Dostal, J., Lee, J.K.W., and Ortega-Rivera, A., 2012A, Constraints on the subduction erosion/extrusion cycle in the Paleozoic Acatlán Complex of southern Mexico: Geochemistry and geochronology of the type Piaxtla Suite: Gondwana Research, v. 21, no. 4, p. $1050-1065$.

Keppie, J.D., Dostal, J., Murphy, J.B., Galaz-Escanilla, G., Ramos-Arias, M.A., and Nance, R.D., 2012B, High pressure rocks of the Acatlán Complex, southern Mexico: Large-scale subducted Ordovician rifted passive margin extruded into the upper plate during the Devonian-Carboniferous:

Tectonophysics, v. 560-561, p. 1-21.

Keppie, J.D., Nance, R.D., Ramos-Arias, M.A., Lee, J.K.W., Dostal, J., Ortega-Rivera, A., and Murphy, J.B., 2010, Late Paleozoic subduction and exhumation of Cambro-Ordovician passive margin and arc rocks in the northern Acatlán Complex, southern Mexico: Geochronological constraints: Tectonophysics, v. 495, no. 3, p. 213-229.

Keppie, J.D., and Ortega-Gutierrez, F., 1999, Middle American Precambrian basement: A missing piece of the reconstructed 1-Ga orogen: Geological Society of America Special Papers, v. 336, p. 199-210.

Kirsch, M., Keppie, J.D., Murphy, J.B., and Solari, L.A., 2012, Permian-Carboniferous arc magmatism and basin evolution along the western margin of Pangea: Geochemical and geochronological evidence from the eastern Acatlán Complex, southern Mexico: Geological Society of America Bulletin, v. 124, no. 9-10, p. 1607-1628.

Kovach, A., Hurley, P.M., and Fairbairn, H.W., 1977, Rb-Sr Whole Rock Dating of Metamorphic Events in the Iglesias Complex, Venezuelan Andes: The Journal of Geology, v. 85, p. 372-377.

Kovisars, L., 1971, Geology of a portion of the north-central Venezuelan Andes: Geological Society of America Bulletin, v. 82, no. 11, p. 3111-3138.

De La Roche, H., Leterrier, J., Grandclaude, P., and Marchal, M., 1980, A classification of volcanic and plutonic rocks using R1R2-diagram and major-element analyses--Its relationships with current nomenclature: Chemical Geology, v. 29, no. 1-4, p. 183-210.

Larrovere, M.A., de los Hoyos, C.R., Toselli, A.J., Rossi, J.N., Basei, M.A., and Belmar, M.E., 2011, High T/P evolution and metamorphic ages of the migmatitic basement of northern Sierras Pampeanas, Argentina: Characterization of a mid-crustal segment of the Famatinian belt: Journal of South American Earth Sciences, v. 31, no. 2, p. 279-297. 
Laya, J.C., and Tucker, M.E., 2012, Facies analysis and depositional environments of Permian carbonates of the Venezuelan Andes: Palaeogeographic implications for Northern Gondwana: Palaeogeography, Palaeoclimatology, Palaeoecology, v. 331-332, p. 1-26.

Van der Lelij, R., Spikings, R.A., Kerr, A.C., Kounov, A., Cosca, M., Chew, D., and Villagómez, D., 2010, Thermochronology and tectonics of the Leeward Antilles: Evolution of the southern Caribbean Plate boundary zone: Tectonics, v. 29, no. 6, p. 1-30.

Linnemann, U., Pereira, F., Jeffries, T.E., Drost, K., and Gerdes, A., 2008, The Cadomian Orogeny and the opening of the Rheic Ocean: The diacrony of geotectonic processes constrained by LA-ICP-MS U$\mathrm{Pb}$ zircon dating (Ossa-Morena and Saxo-Thuringian Zones, Iberian and Bohemian Massifs): Tectonophysics, v. 461, no. 1-4, p. 21-43.

Litherland,M., Aspden, J.A., Jemielita, R.A., 1994. Themetamorphic belts of Ecuador. Overseas Memoir of the British Geological Survey, 11, p. 147 (Nottingham, England).Lucassen, F., and Franz, G., 2005, The Early Palaeozoic Orogen in the Central Andes: a non-collisional orogen comparable to the Cenozoic high plateau?: Geological Society, London, Special Publications, v. 246, no. 1, p. $257-$ 273.

Ludwig, K.R., 2003, User’s Manual for Isoplot 3.00: A geochronological toolkit for Microsoft Excel.

Maas, R., Nicholls, I.A., and Legg, C., 1997, Igneous and metamorphic enclaves in the S-type Deddick granodiorite, Lachlan Fold Belt, SE Australia: petrographic, geochemical and $\mathrm{Nd}-\mathrm{Sr}$ isotopic evidence for crustal melting and magma mixing: Journal of Petrology, v. 38, no. 7, p. 815-841.

Macellari, C., 1984, Late Tertiary tectonic history of the Táchira Depression, southwestern Venezuelan Andes: The Caribbean-South American plate boundary and regional tectonics: Geological Society of America Memoir, v. 162, p. 333-340.

Maniar, P.D., and Piccoli, P.M., 1989, Tectonic discrimination of granitoids: Geological Society of America Bulletin, v. 101, no. 5, p. 635-643.

Mantilla, L.C., Valencia, V.A., Barra, F., Pinto, J., and Colegial, J., 2009, U-Pb geochronology from porphyry rocks in the Vetas-California gold mining area (Santander, Colombia): Boletin de Geología, v. 31, p. 31-43.

Mantilla, L.C., Bissig, T., Cottle, J.M., and Hart, C.J.R., 2012, Remains of early Ordovician mantle-derived magmatism in the Santander Massif (Colombian Eastern Cordillera): Journal of South American Earth Sciences, v. 38, p. 1-12.

Mantilla, L.C., Bissig, T., Valencia, V., and Hart, C.J., 2013, The magmatic history of the Vetas-California mining district; Santander massif, eastern Cordillera, Colombia: Journal of South American Earth Sciences, v. 45, p. 235-249.

Maréchal, P., 1983, Les témoins de la chaîne hercynienne dans le noyau ancien des Andes de Mérida (Vénézuela), PhD Thesis, Université de Brest, France: 174 p.

Martens, U., Weber, B., and Valencia, V.A., 2010, U/Pb geochronology of Devonian and older Paleozoic beds in the southeastern Maya block, Central America: Its affinity with peri-Gondwanan terranes: Geological Society of America Bulletin, v. 122, no. 5-6, p. 815-829.

Martin-Bellizzia, C., Ramírez, C., Menéndez, A., Ríos, J.H., and Benaim, N., 1968, Edades isotópicas de rocas venezolanas: Boletin de Geología, Caracas, v. 10, no. 19, p. 356-380. 
Maze, W.B., 1984, Jurassic la Quinta Formation in the Sierra de Perijá, northwestern Venezuela: geology and tectonic environment of red beds and volcanic rocks: The Caribbean-South American plate boundary and regional tectonics: Geological Society of America Memoir, v. 162, p. 263-282.

McKerrow, W.S., Mac Niocaill, C., Ahlberg, P.E., Clayton, G., Cleal, C.J., and Eagar, R.M.C., 2000, The late Palaeozoic relations between Gondwana and Laurussia: Geological Society, London, Special Publications, v. 179, no. 1, p. 9-20.

McLoughlin, S., Lindström, S., and Drinnan, A.N., 1997, Gondwanan floristic and sedimentological trends during the Permian-Triassic transition: new evidence from the Amery Group, northern Prince Charles Mountains, East Antarctica: Antarctic Science, v. 9, no. 03, p. 281-298.

Menzies, M.A., Klemperer, S.L., Ebinger, C.J., Baker, J., 2002. Characteristics of volcanic rifted margins. Geological Society of America Special Papers 362; 1-14.

Miller, B.V., Dostal, J., Keppie, J.D., Nance, R.D., Ortega-Rivera, A., and Lee, J.K.., 2007, Ordovician calcalkaline granitoids in the Acatlán Complex, southern México: Geochemical and geochronologic data and implications for the tectonics of the Gondwanan margin of the Rheic Ocean: Geological Society of America Special Paper, v. 423, p. 465-475.

Miller, H., and Söllner, F., 2005, The Famatina complex (NW Argentina): back-docking of an island arc or terrane accretion? Early Palaeozoic geodynamics at the western Gondwana margin: Geological Society, London, Special Publications, v. 246, no. 1, p. 241-256.

Mišković, A., Spikings, R.A., Chew, D.M., Košler, J., Ulianov, A., and Schaltegger, U., 2009, Tectonomagmatic evolution of Western Amazonia: Geochemical characterization and zircon U-Pb geochronologic constraints from the Peruvian Eastern Cordilleran granitoids: Geological Society of America Bulletin, v. 121, no. 9-10, p. 1298-1324.

Mojica, J., Kammer, A., and Ujueta, G., 1996, El Jurásico del Sector Noroccidental de Suramérica: Geología Colombiana, v. 21, p. 3-40.

Mojica, J., and Villarroel, C., 1990, Sobre la distribución y facies del Paleozoico Inferior sedimentario en el extremo NW de Sudamérica: Geología Colombiana, v. 17, p. 219-226.

Montes, C., Guzman, G., Bayona, G., Cardona, A., Valencia, V., and Jaramillo, C., 2010, Clockwise rotation of the Santa Marta massif and simultaneous Paleogene to Neogene deformation of the Plato-San Jorge and Cesar-Ranchería basins: Journal of South American Earth Sciences, v. 29, no. 4, p. 832848.

Moreno-Lopez, C., 2012, Evolution of the Southern Llanos basin, Colombia [MSc thesis]: University of Stavanger, $80 \mathrm{p}$.

Murphy, J.B., Fernández-Suárez, J., Jeffries, T.E., and Strachan, R.A., 2004, U-Pb (LA-ICP-MS) dating of detrital zircons from Cambrian clastic rocks in Avalonia: erosion of a Neoproterozoic arc along the northern Gondwanan margin: Journal of the Geological Society, v. 161, no. 2, p. 243-254.

Nance, R.D., Gutiérrez-Alonso, G., Keppie, J.D., Linnemann, U., Murphy, J.B., Quesada, C., Strachan, R.A., and Woodcock, N.H., 2010, Evolution of the Rheic Ocean: Gondwana Research, v. 17, no. 2-3, p. 194-222.

Nance, R.D., Murphy, J.B., Strachan, R.A., Keppie, J.D., Gutiérrez-Alonso, G., Fernández-Suárez, J., Quesada, C., Linnemann, U., D'lemos, R., and Pisarevsky, S.A., 2008, Neoproterozoic-early Palaeozoic tectonostratigraphy and palaeogeography of the peri-Gondwanan terranes: Amazonian v. West African connections: Geological Society, London, Special Publications, v. 297, no. 1, p. 345383. 
Nivia, A., Marriner, G.F., Kerr, A.C., and Tarney, J., 2006, The Quebradagrande Complex: A Lower Cretaceous ensialic marginal basin in the Central Cordillera of the Colombian Andes: Journal of South American Earth Sciences, v. 21, no. 4, p. 423-436.

Noble, S.R., Aspden, J.A., and Jemielita, R., 1997, Northern Andean crustal evolution: New U-Pb geochronological constraints from Ecuador: Geological Society of America Bulletin, v. 109, no. 7, p. 789-798.

Odremán, O., and Useche, A., 1997, Léxico Estratigráfico de Venezuela: Caracas, Venezuela.

Ordóñez-Carmona, O., Restrepo Álvarez, J.J., and Pimentel, M.M., 2006, Geochronological and isotopical review of pre-Devonian crustal basement of the Colombian Andes: Journal of South American Earth Sciences, v. 21, no. 4, p. 372-382.

Ostos, M., Yoris, F., and Lallemant, H.G.A., 2005, Overview of the southeast Caribbean-South American plate boundary zone: Geological Society of America Special Papers, v. 394, p. 53-89.

Passchier, C.W., and Trouw, R.A.J., 2005, Microtectonics: Springer Verlag, Heidelberg.

Patiño-Douce, A.E., 1999, What do experiments tell us about the relative contributions of crust and mantle to the origin of granitic magmas?: Geological Society, London, Special Publications, v. 168, no. 1, p. $55-75$.

Pearce, J.A., 1996, Sources and settings of granitic rocks: Episodes, v. 19, no. 4, p. 120-125.

Peccerillo, A., and Taylor, S.R., 1976, Geochemistry of Eocene calc-alkaline volcanic rocks from the Kastamonu area, Northern Turkey: Contributions to Mineralogy and Petrology, v. 58, no. 1, p. 6381.

Peterman, E.M., and Grove, M., 2010, Growth conditions of symplectic muscovite+ quartz: Implications for quantifying retrograde metamorphism in exhumed magmatic arcs: Geology, v. 38, no. 12, p. 10711074.

Pindell, J., and Dewey, J., 1982, Permo-Triassic reconstruction of western pangea and the evolution of the gulf of mexico/caribbean region: Tectonics, v. 1, no. 2, p. 179-211.

Pollock, J.C., Hibbard, J.P., and Sylvester, P.J., 2009, Early Ordovician rifting of Avalonia and birth of the Rheic Ocean: U-Pb detrital zircon constraints from Newfoundland: Journal of the Geological Society, v. 166, no. 3, p. 501-515.

Ramos, V.A., 2009, Anatomy and global context of the Andes: Main geologic features and the Andean orogenic cycle: Backbone of the Americas: Shallow Subduction, Plateau Uplift, and Ridge and Terrane Collision: Geological Society of America Memoir, v. 204, p. 31-65.

Ramos, V.A., 2010, The Grenville-age basement of the Andes: Journal of South American Earth Sciences, v. 29 , no. 1, p. 77-91.

Rapela, C.W., Pankhurst, R.J., Casquet, C., Baldo, E., Saavedra, J., and Galindo, C., 1998, Early evolution of the Proto-Andean margin of South America: Geology, v. 26, no. 8, p. 707-710.

Ratschbacher, L., Franz, L., Min, M., Bachmann, R., Martens, U., Stanek, K., Stübner, K., Nelson, B.K., Herrmann, U., and Weber, B., 2009, The North American-Caribbean Plate boundary in MexicoGuatemala-Honduras: Geological Society, London, Special Publications, v. 328, no. 1, p. 219-293. 
Reitsma, M.J., 2012. Reconstructing the Late Paleozoic: Early Mesozoic plutonic and sedimentary record of south-east Peru: Orphaned back-arcs along the western margin of Gondwana. PhD Thesis, University of Geneva, Switzerland.

Restrepo, J.J., Ordóñez-Carmona, O., Armstrong, R., and Pimentel, M.M., 2011, Triassic metamorphism in the northern part of the Tahamí Terrane of the central cordillera of Colombia: Journal of South American Earth Sciences, v. 32, no. 4, p. 497-507.

Restrepo-Pace, P.A., 1995, Late Precambrian to Early Mesozoic tectonic evolution of the Colombian Andes, based on new geochronological geochemical and isotopic data. [PhD Thesis, University of Arizona, USA]: $195 \mathrm{p}$.

Restrepo-Pace, P.A., and Cediel, F., 2010, Northern South America basement tectonics and implications for paleocontinental reconstructions of the Americas: Journal of South American Earth Sciences, v. 29, p. 764-771.

Restrepo-Pace, P.A., Ruiz, J., Gehrels, G., and Cosca, M., 1997, Geochronology and Nd isotopic data of Grenville-age rocks in the Colombian Andes: new constraints for Late Proterozoic-Early Paleozoic paleocontinental reconstructions of the Americas: Earth and Planetary Science Letters, v. 150, no. 3, p. $427-441$.

Ríos, C., García, C., and Takasu, A., 2003, Tectono-metamorphic evolution of the Silgará Formation metamorphic rocks in the southwestern Santander Massif, Colombian Andes: Journal of South American Earth Sciences, v. 16, no. 2, p. 133-154.

Ross, C.A., 1986, Paleozoic evolution of southern margin of Permian basin: Geological Society of America Bulletin, v. 97, no. 5, p. 536-554.

Ruiz, J., Tosdal, R.M., Restrepo, P.A., and Murillo-Muñetón, G., 1999, Pb isotope evidence for Colombiasouthern México connections in the Proterozoic: Geological Society of America Special Papers, v. 336, p. 183-197.

Schandl, E.S., and Gorton, M.P., 2002, Application of high field strength elements to discriminate tectonic settings in VMS environments: Economic Geology, v. 97, no. 3, p. 629-642.

Schubert, C., 1969, Geologic structure of a part of the Barinas mountain front, Venezuelan Andes: Geological Society of America Bulletin, v. 80, no. 3, p. 443-548.

Schubert, C., Sifontes, R., Velez, V., and Loaiza, P.A., 1979, Formación La Quinta (Jurasico) Andes Merideños: Geología de la sección tipo: Acta Científica Venezolana, v. 30, no. 1, p. 42-55.

Sempere, T., 1995, Phanerozoic evolution of Bolivia and adjacent regions: AAPG Memoir, v. 62, p. 207230.

Shagam, R., and Grauch, R.I., 2006, A major metamorphic problem in the Venezuelan Andes, in Abstracts Israel Geological Society, Israel Geological Society, p. 111.

Shagam, R., Kohn, B.P., Banks, P.O., Dasch, L.E., Vargas, R., Rodriguez, G.I., and Pimentel, N., 1984, Tectonic implications of Cretaceous-Pliocene fission-track ages from rocks of the circum-Maracaibo Basin region of western Venezuela and eastern Colombia: Geological Society of America Memoir, v. 162 , p. 385-412.

Shanks, W.C.P., III, and Thurston, R., eds., 2012, Volcanogenic Massive Sulfide Occurrence Model: U.S. Geological Survey Scientific Investigations Report, v. 2010-5070-C, p. 345. 
Shinjo, R., and Kato, Y., 2000, Geochemical constraints on the origin of bimodal magmatism at the Okinawa Trough, an incipient back-arc basin: Lithos, v. 54, no. 3, p. 117-137.

Sisson, V.B., Lallemant, H.G.A., Ostos, M., Blythe, A.E., Snee, L.W., Copeland, P., Wright, J.E., Donelick, R.A., and Guth, L.R., 2005, Overview of radiometric ages in three allochthonous belts of northern Venezuela: Old ones, new ones, and their impact on regional geology: Geological Society of America Special Papers, v. 394, p. 91-117.

Slama, J., Kosler, J., Condon, D.J., Crowley, J.L., Gerdes, A., Hanchar, J.M., Horstwood, M.S.., Morris, G.A., Nasdala, L., and Norberg, N., 2008, Plesovice zircon--A new natural reference material for U$\mathrm{Pb}$ and $\mathrm{Hf}$ isotopic microanalysis: Chemical Geology, v. 249, no. 1-2, p. 1-35.

Solari, L.A., García-Casco, A., Martens, U., Lee, J.K.W., and Ortega-Rivera, A., 2013, Late Cretaceous subduction of the continental basement of the Maya block (Rabinal Granite, central Guatemala): Tectonic implications for the geodynamic evolution of Central America: Geological Society of America Bulletin, v. 125, no. 3/4, p. 625-639, doi: 10.1130/B30743.1.

Spear, F.S., 1993, Metamorphic phase equilibria and pressure-temperature-time paths: Mineralogical Society of America, Washington.

Spear, F.S., Kohn, M.J., and Cheney, J.T., 1999, P-T paths from anatectic pelites: Contributions to Mineralogy and Petrology, v. 134, no. 1, p. 17-32.

Spikings, R., Cochrane, R., Villagomez, D., van der Lelij, R., Vallejo, C., Winkler, W., and Beate, B., 2014 The geological history of northwestern South America: from Pangaea to the early collision of the Caribbean Large Igneous Province (290-75 Ma). Gondwana Research

Van Staal, C.R., Barr, S.M., and Murphy, J.B., 2012, Provenance and tectonic evolution of Ganderia: Constraints on the evolution of the Iapetus and Rheic oceans: Geology,, p. in press.

Van Staal, C.R., and Hatcher, R.D., 2010, Global setting of Ordovician orogenesis: The Ordovician Earth System. Edited by SC Finney and WBN Berry. Geological Society of America, Special Paper, v. 466, p. 1-11.

Staargaard, C.F., and Carlson, G.C., 2000, The Bailadores volcanogenic massive sulphide deposit, Venezuela, in Sherlock, R.L. and Logan, M.A. eds., Volcanogenic massive sulphide deposits of Latin America, Geological Association of Canada Special Publication, p. 315-323.

Stacey, J.S., and Kramers, J.D., 1975, Approximation of terrestrial lead isotope evolution by a two-stage model: Earth and Planetary Science Letters, v. 26, no. 2, p. 207-221.

Stewart, J.H., Blodgett, R.B., Boucot, A.J., Carter, J.L., López, R., Ramos, V.A., and Keppie, J.D., 1999, Exotic Paleozoic strata of Gondwanan provenance near Ciudad Victoria, Tamaulipas, Mexico: Geological Society of America Special Paper, v. 336, p. 227-252.

Suárez Díaz, H.G., and Solano, Y.P., 2012, El Paleozoico en los Llanos Orientales de Colombia: Una nueva ventana en la búsqueda de fuentes de hidrocarburos: Revista de la Asociación Colombiana de Geólogos y Geofisicos del Petróleo, v. 14, p. 8-11.

Taylor, S.R., and McLennan, S.M., 1985, The continental crust: its composition and evolution: Blackwell, Oxford, $311 \mathrm{p}$.

Torsvik, T.H., and Cocks, L.R.M., 2004, Earth geography from 400 to 250 Ma: a palaeomagnetic, faunal and facies review: Journal of the Geological Society, v. 161, no. 4, p. 555-572. 
Torsvik, T.H., Van der Voo, R., Preeden, U., Mac Niocaill, C., Steinberger, B., Doubrovine, P.V., van Hinsbergen, D.J.J., Domeier, M., Gaina, C., Tohver, E., Meert, J., and Cocks, L.R.M., 2012, Phanerozoic polar wander, palaeogeography and dynamics: Earth-Science Reviews, v. 114, p. 325368.

Tosdal, R.M., 1996, The Amazon-Laurentian connection as viewed from the Middle Proterozoic rocks in the central Andes, western Bolivia and northern Chile: Tectonics, v. 15, no. 4, p. 827-842.

Toussaint, J.F., and Restrepo, J.J., 1988, Son Alóctonos los Andes Colombianos?, Rev. ICNE, Univ. Nac. Medellín, v. 1, p. 17 - 41

Troth, I., Marshall, J.E.A., Racey, A., and Becker, R.T., 2011, Devonian sea-level change in Bolivia: A high palaeolatitude biostratigraphical calibration of the global sea-level curve: Palaeogeography, Palaeoclimatology, Palaeoecology, v. 304, no. 1, p. 3-20.

Ulianov, A., Müntener, O., Schaltegger, U., and Bussy, F., 2012, The data treatment dependent variability of $\mathrm{U}-\mathrm{Pb}$ zircon ages obtained using mono-collector, sector field, laser ablation ICPMS: Journal of Analytical Atomic Spectrometry, v. 27, no. 4, p. 663-676.

Urueña-Suárez, C.L., and Zuluaga, C.A., 2011, Petrography of the Bucaramanga Gneiss near to Cepita, Berlin and Vetas - Santander: Geología Colombiana, v. 36, no. 1, p. 37-56.

Vega-Granillo, R., Calmus, T., Meza-Figueroa, D., Ruiz, J., Talavera-Mendoza, O., and López-Martínez, M., 2009, Structural and tectonic evolution of the Acatlán Complex, southern Mexico: its role in the collisional history of Laurentia and Gondwana: Tectonics, v. 28, no. 4, p. TC4008.

Vega-Granillo, R., Talavera-Mendoza, O., Meza-Figueroa, D., Ruiz, J., Gehrels, G.E., López-Martínez, M., and Julio, C., 2007, Pressure-temperature-time evolution of Paleozoic high-pressure rocks of the Acatlán Complex (southern Mexico): Implications for the evolution of the Iapetus and Rheic Oceans: Geological Society of America Bulletin, v. 119, no. 9-10, p. 1249-1264.

Villagómez, D., Spikings, R., Magna, T., Kammer, A., Winkler, W., and Beltrán, A., 2011, Geochronology, geochemistry and tectonic evolution of the Western and Central cordilleras of Colombia: Lithos, v. 125 , no. 3, p. $875-896$.

Vinasco, C.J., Cordani, U.G., González, H., Weber, M., and Pelaez, C., 2006, Geochronological, isotopic, and geochemical data from Permo-Triassic granitic gneisses and granitoids of the Colombian Central Andes: Journal of South American Earth Sciences, v. 21, no. 4, p. 355-371.

Viscarret, P., Wright, J., and Urbani, F., 2009, New U-Pb zircon ages of El Baúl Massif, Cojedes State, Venezuela: Revista Técnica de la Facultad de Ingeniería. Universidad del Zulia, v. 32, no. 3, p. 210221.

Von Quadt, A., Gallhofer, D., Guillong, M., Peytcheva, I., Waelle, M., Sakata, S., 2014. U-Pb dating of CA/non-CA treated zircons obtained by LA-ICP-MS and CA-TIMS techniques: impact for their geological interpretation. Journal of Analytical Atomic Spectrometry.

Ward, D.E., Goldsmith, R., Jaime, B., and Restrepo, H.A., 1974, Geology of quadrangles H-12, H-13, and parts of I-12 and I-13, (zone III) in northeastern Santander Department, Colombia: U.S. Geological Survey.

Wiedenbeck, M., Alle, P., Corfu, F., Griffin, W.L., Meier, M., Oberli, F., Quadt, A., Roddick, J.C., and Spiegel, W., 1995, Three natural zircon standards for U Th Pb, Lu Hf, trace element and REE analyses: Geostandards and Geoanalytical Research, v. 19, no. 1, p. 1-23. 
Yañez, P., Ruiz, J., Patchett, P.J., Ortega-Gutierrez, F., and Gehrels, G.E., 1991, Isotopic studies of the Acatlan complex, southern Mexico: Implications for Paleozoic North American tectonics:

Geological Society of America Bulletin, v. 103, no. 6, p. 817-828.

\section{Figure Captions}

Figure 1. Digital relief map (Amante and Eakins, 2008) showing the tectonic provinces of northern South America modified from Feo-Codecido et al. (1984) and Ostos et al. (2005). The locations of geological maps in Figures 2 and 4 are highlighted in dashed red boxes. BB: Bonaire Block, CC: Central Cordillera, CM: Caribbean Mountains, EB: El Baúl Massif, EC: Eastern Cordillera, FM: Floresta Massif, GM: Garzón Massif, LB: Llanos Basin, MA: Mérida Andes, MTB: Maracaibo Triangular Block, PP: Paraguana Peninsuala, QM: Quetame Massif, SL: Serranía de San Lucas, SMBF: Santa Marta-Bucaramanga Fault, SM: Santander Massif, SNSM: Sierra Nevada de Santa Marta, SP: Sierra del Perijá, TI: Toas Island.

Figure 2: Geological map of the Mérida Andes, Venezuela, simplified and modified from Hackley et al. (2005). Locations of all analysed samples are shown. Sample codes in parentheses (XX) correspond to full sample codes 08VDLXX. All quoted ages are new weighted mean zircon ${ }^{206} \mathrm{~Pb} /{ }^{238} \mathrm{U}$ dates obtained during this study with uncertainties at the $2 \sigma$ confidence level. Location of the main faults and the Caparo Block are shown.

Figure 3: Compilation of previously obtained geochronological data from the Mérida Andes (Bass and Shagam, 1959; Compañia Shell de Venezuela and Creole Petroleum Corporation, 1964; Martin-Bellizzia et al., 1968; Schubert, 1969; Burkley, 1976; Kovach et al., 1977; Schubert et al., 1979; Etchart and Cordani, 1981; Cordani et al., 1985). Colour coding is according to analytical method utilised, and box size is a function of the quoted uncertainty (confidence levels are unspecified). Initial ${ }^{87} \mathrm{Sr} /{ }^{86} \mathrm{Sr}$ ratios used for $\mathrm{Rb} / \mathrm{Sr}$ model ages $=0.705$.

Figure 4: Geological map of the Santander Massif, Colombia, simplified and modified from Gómez et al. (2007). Sample codes in parentheses (XX) correspond to full sample codes 10VDLXX. All quoted ages are new weighted mean zircon ${ }^{206} \mathrm{~Pb} /{ }^{238} \mathrm{U}$ dates obtained during this study with uncertainties at the $2 \sigma$ confidence level. The Bocas Fm. (Permian?) is included with Jurassic sedimentary rocks as available base maps do not differentiate them.

Figure 5: Compilation of previously obtained geochronological data from the Santander Massif (Goldsmith et al., 1971; Boinet et al., 1985; Cordani et al., 2005; Dörr et al., 1995; Restrepo-Pace, 1995, 1997; RestrepoPace and Cediel, 2010; Mantilla et al., 2009, 2012, 2013). ${ }^{40} \mathrm{Ar} /{ }^{39} \mathrm{Ar}$ dates include integrated dates from discordant spectra. Initial ${ }^{87} \mathrm{Sr} /{ }^{86} \mathrm{Sr}$ ratios used for $\mathrm{Rb} / \mathrm{Sr}$ model ages $=0.705$. Note the change in scale of the time axis at $300 \mathrm{Ma}$.

Figure 6: Probability density plot for U-Pb dates from detrital zircon sample 08VDL05. The dates used are ${ }^{206} \mathrm{~Pb} /{ }^{238} \mathrm{U}$ dates for spots younger than $0.9 \mathrm{Ga}$ and ${ }^{207} \mathrm{~Pb} /{ }^{206} \mathrm{~Pb}$ dates for spots older than $0.9 \mathrm{Ga}$.

Figure 7: Photomicrographs of microtextures discussed in the text. Bt: biotite, chl: chlorite, fsp: feldspar, hbl: hornblende, ms: muscovite, myr: myrmekite, pl: plagioclase, sil: sillimanite, sph: sphene. A) Crossed polarized light photomicrograph of sample 08VDL11 (Micarache anatectic orthogneiss, Mérida Andes) showing randomly oriented muscovite replacing sillimanite. In the top left, muscovite forms symplectites with feldspar and quartz. B) Another photomicrograph of 08VDL11 showing the symplectite of muscovite, biotite and myrmekite. C) Crossed polarised light photomicrograph of Mitisus striped gneiss sample 08VDL26, Mérida Andes, showing typical elongated quartz crystals around feldspar augen with biotite growing in strain shadows. D) Plane polarized light photomicrograph of the Bucaramanga gneiss sample 10VDL23, Santander Massif, showing the poikiloblastic structure and its relationship to chlorite and hornblende.

Figure 8: Concordia plot of data obtained from the Micarache orthogneiss, 08VDL11. Error ellipses are $\pm 2 \sigma$. Clustered blue ellipses are interpreted to reflect the timing of protolith crystallisation and anatexis, and 
orange ellipses are considered to be mixed domains between the two populations. Quoted ages are weighted mean ${ }^{206} \mathrm{~Pb} /{ }^{238} \mathrm{U}$ ages. $\mathrm{N}$ : number of individual zircon ages included in weighted mean calculation. MSWD: Mean Squared Weighted Deviates.

Figure 9: Photograph showing crosscutting relationships between different rock units in the Santander Massif. Orthogneiss (A) is probably related to Ordovician sample 10VDL37, and forms schollen in the migmatite structure (B). The fabric is crosscut by an undeformed granitic dike (C), which may relate to Early Jurassic granitoid 10VDL05 (Corcova granitodiorite, Table 1). The migmatites in this picture (10VDL39) yield a weighted mean zircon ${ }^{206} \mathrm{~Pb} /{ }^{238} \mathrm{U}$ age of $208.8 \pm 1.2 \mathrm{Ma}$. The hammer in the picture is for scale.

Figure 10: Concordia plots of zircon U-Pb data obtained from the Rio Surata granodiorite (10VDL61). Error ellipses are $\pm 2 \sigma$. Blue ellipses were used to calculate weighted mean ${ }^{206} \mathrm{~Pb} /{ }^{238} \mathrm{U}$ ages, and the orange ellipse was discarded from calculations as it may reflect $\mathrm{Pb}$ loss. The older population is considered to be derived from one of the numerous enclaves in this rock. N: number of individual zircon ages included in weighted mean calculation. MSWD: Mean Squared Weighted Deviates.

Figure 11: Geochemical data plots for major and trace element data obtained during this study. Colour coding of symbols is identical in all graphs, and reflects sample region and age as shown in the legend. (A) $\mathrm{K}_{2} \mathrm{O}$ vs $\mathrm{SiO}_{2}$ plot with fields from Peccerillo and Taylor (1976). (B) Shand's index plot with fields from Maniar and Piccoli (1989). (C) $\mathrm{Na}_{2} \mathrm{O}$ vs $\mathrm{K}_{2} \mathrm{O}$ I-Type / S-Type discriminant after Chappell and White (1974). (D) Tectonic discrimination plot for granitoids with fields from Pearce (1996); ORG: ocean ridge granite, PC: post-collisional granite, syn-COLG: syn-collisional granite, VAG: volcanic arc granite, WPG: within plate granite. Fields for data from Permian to Triassic (orange outlines) and Jurassic (blue outlines) granitoids from Colombia and Ecuador are compiled from Litherland et al. (1994), Vinasco et al. (2006) and Cardona et al. (2010, 2014).

Figure 12: Trace element and rare earth element plots for unaltered samples from the Merida Andes and the Santander Massif. All plots are normalized to upper continental crust (Taylor and McLennan, 1985).

Figure 13: Isotope correlation diagram displaying present-day uranogenic $\mathrm{Pb}$ isotopic compositions. The field for age-corrected initial ratios is shaded in grey. See Figure 11 for colour coding of samples. Pb isotopic fields from major basement units in Colombia (Ruiz et al., 1999) and western Gondwana and Laurentia (Tosdal, 1996 and references therein) are shown for comparison. The thick black curve shows the terrestrial evolution trend (Stacey and Kramers, 1975), and numbers adjacent to tick marks represent Ga before present.

Figure 14 : Synoptic stratigraphic columns for the main basement areas studied in this paper, based on our new data. Pink boxes outline the main periods of magmatic activity. Dated magmatic members of sedimentary formations are also highlighted in pink. Question marks denote an uncertain extent. The only age constraint on the Cerro Azul Suite is that it is Silurian or older (see text for details), and the Bella Vista Suite and Silgará Formation predate the end of the Cambrian. Zigzag lines indicate unconformities discussed in the text. The Pre-Devonian stratigraphy of the Sierra del Perijá and the field relationships of Toas Island and Paraguaná Peninsula are essentially unknown and have not been included here.

Figure 15: Schematic cross-sections for the Early Palaeozoic evolution of the northern Andes based on this study, illustrating the changing geodynamic regime. See text for discussion. AF: Apure fault; CB: Caparo Block, MA: Mérida Andes; SM: Santander Massif. Cardinal directions are in present day coordinates. The Apure Fault is the apparent limit of Early Palaeozoic deformation in Venezuela (see also Feo-Codecido et al. (1984) and its location is marked on Fig. 1.

Figure 16: Proposed plate reconstruction and palaeogeography for the Palaeozoic margin of Gondwana, modified and simplified from Van Staal and Hatcher (2010) and Cocks and Torsvik (2006) with focus on the Gondwanan margin (Famatinian Arc). The region studied in this paper is highlighted with a red box. The structural features of Laurentia, Baltica, Siberia, and peri-Gondwanan terranes are beyond the scope of this paper and are simplified or omitted. The peri-Gondwanan position of the Carolina Terrane may have been similar to Ganderia (van Staal and Hatcher, 2010) and is not shown. Rotation directions for Gondwana at 420 
Ma and $400 \mathrm{Ma}$ (Torsvik et al., 2012) are indicated by black arrows. AC: our preferred position for the Acatlán Complex. For contrasting views see Keppie et al. (2012) and Vega-Granillo et al. (2009), and references therein. CT: Cuyania Terrane (e.g. Astini et al., 1995).

Figure 17: Proposed reconstruction for the evolution of the continental margin between the end of the Permian (a) and the Early Jurassic (b), modified after Weber et al., 2007; Cochrane et al., 2014 and Spikings et al., 2014. Pink shaded areas highlight the approximate extent of active margin magmatism during each period. The Ouachita-Marathon suture is the main collision zone between Gondwana and Laurentia (e.g. Ross, 1986). The Acatlán Complex is included in the Central American block.

Table 1: Summary of geochronological data collected during this study. Full sample codes and GPS Coordinates are shown. Weighted mean zircon ${ }^{206} \mathrm{~Pb} /{ }^{238} \mathrm{U}$ ages were calculated using concordant analyses only. $\mathrm{Th} / \mathrm{U}$ ratios are mean ratios of analyses included in the weighted mean age calculation. The coordinates of sample 08VDL60 are estimated from map coordinates as a result of a GPS malfunction during sampling. See supplementary files for full dataset.

Table 2: Whole rock common $\mathrm{Pb}$ isotopic compositions of analysed igneous and metamorphic rocks from the Mérida Andes and the Santander Massif. Typical analytical uncertainties are $0.0075 \%$ on all measured ratios. Initial compositions were calculated using the measured zircon $\mathrm{U}-\mathrm{Pb}$ age of the rock. 
Figure 1

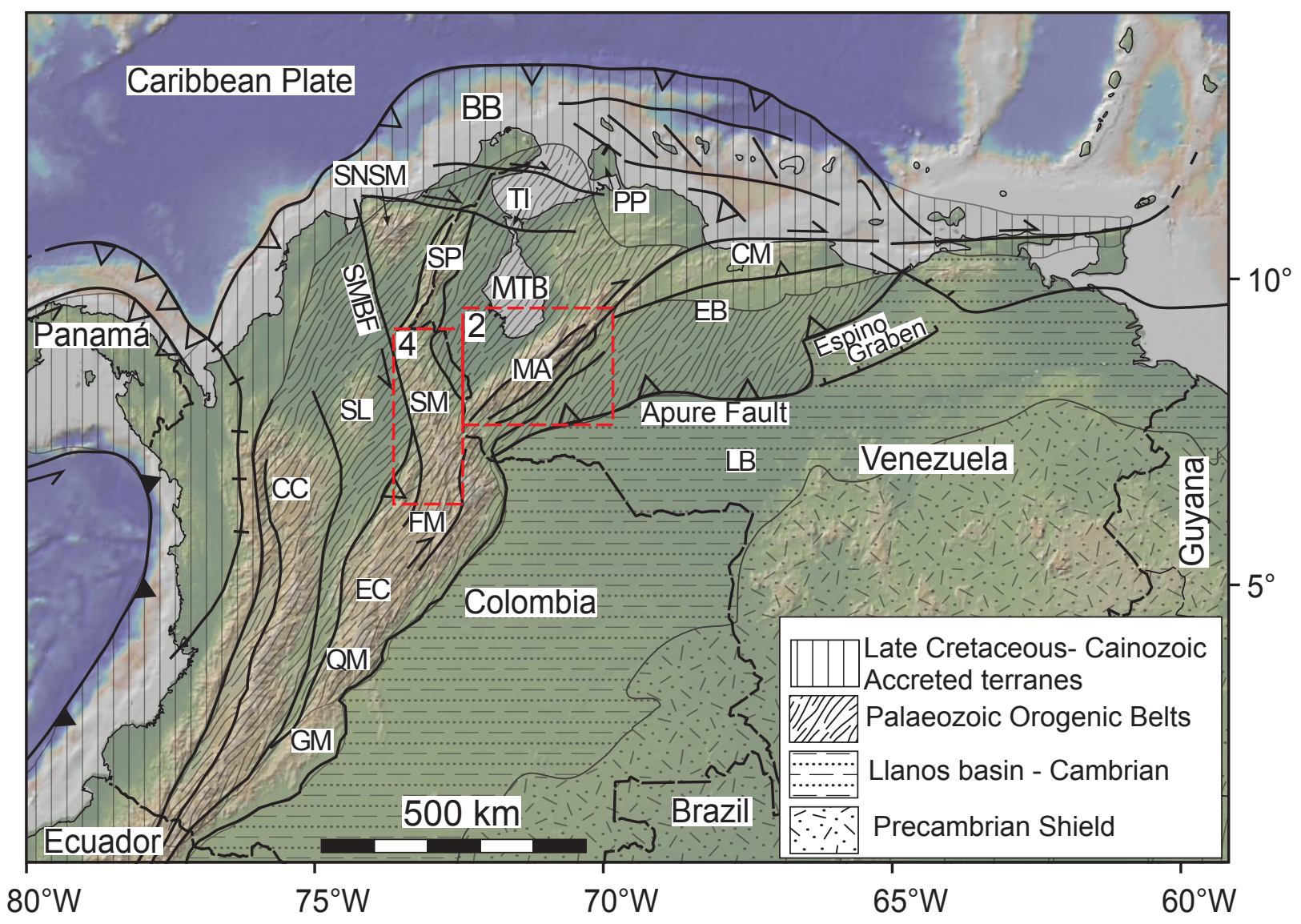




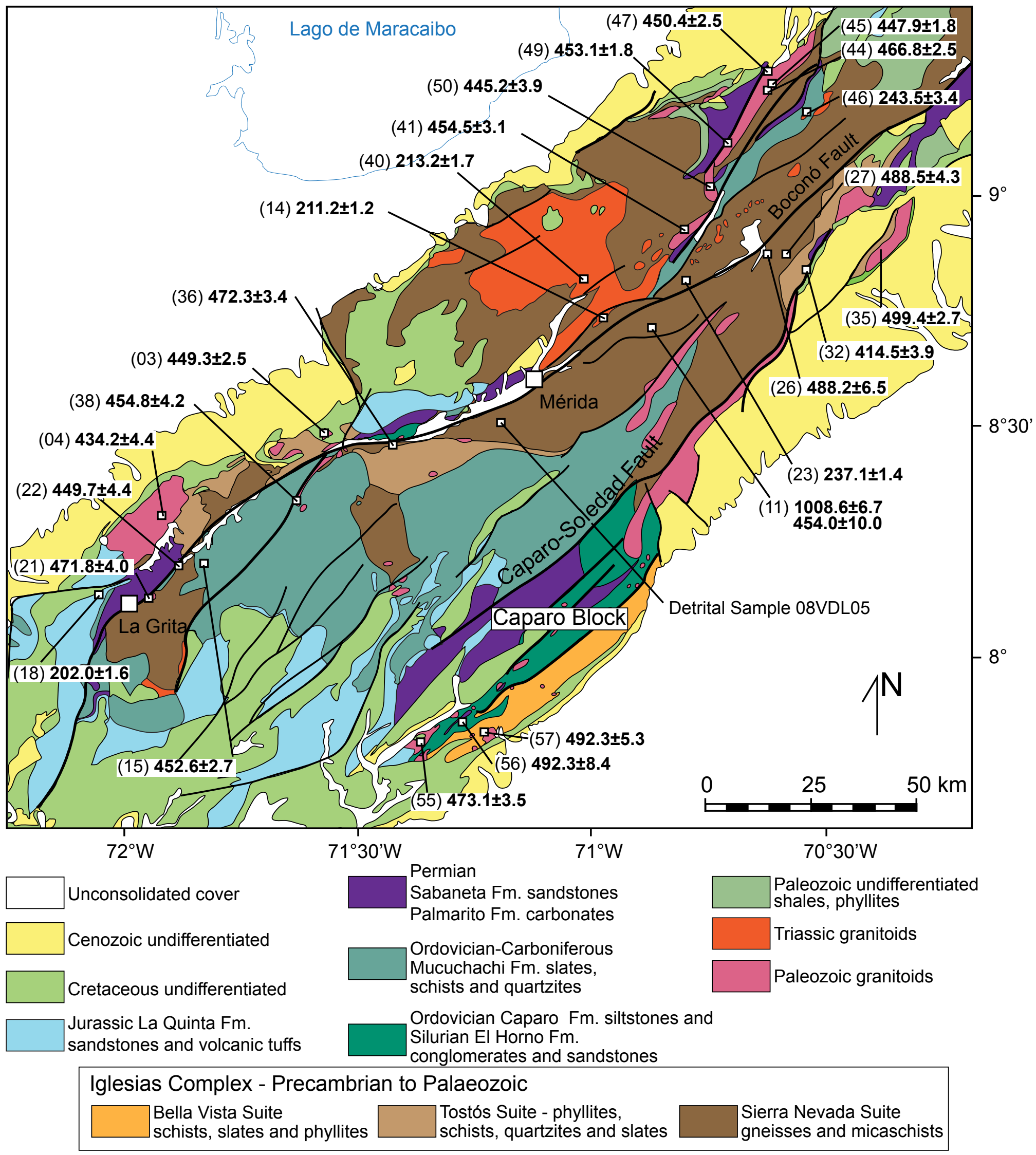




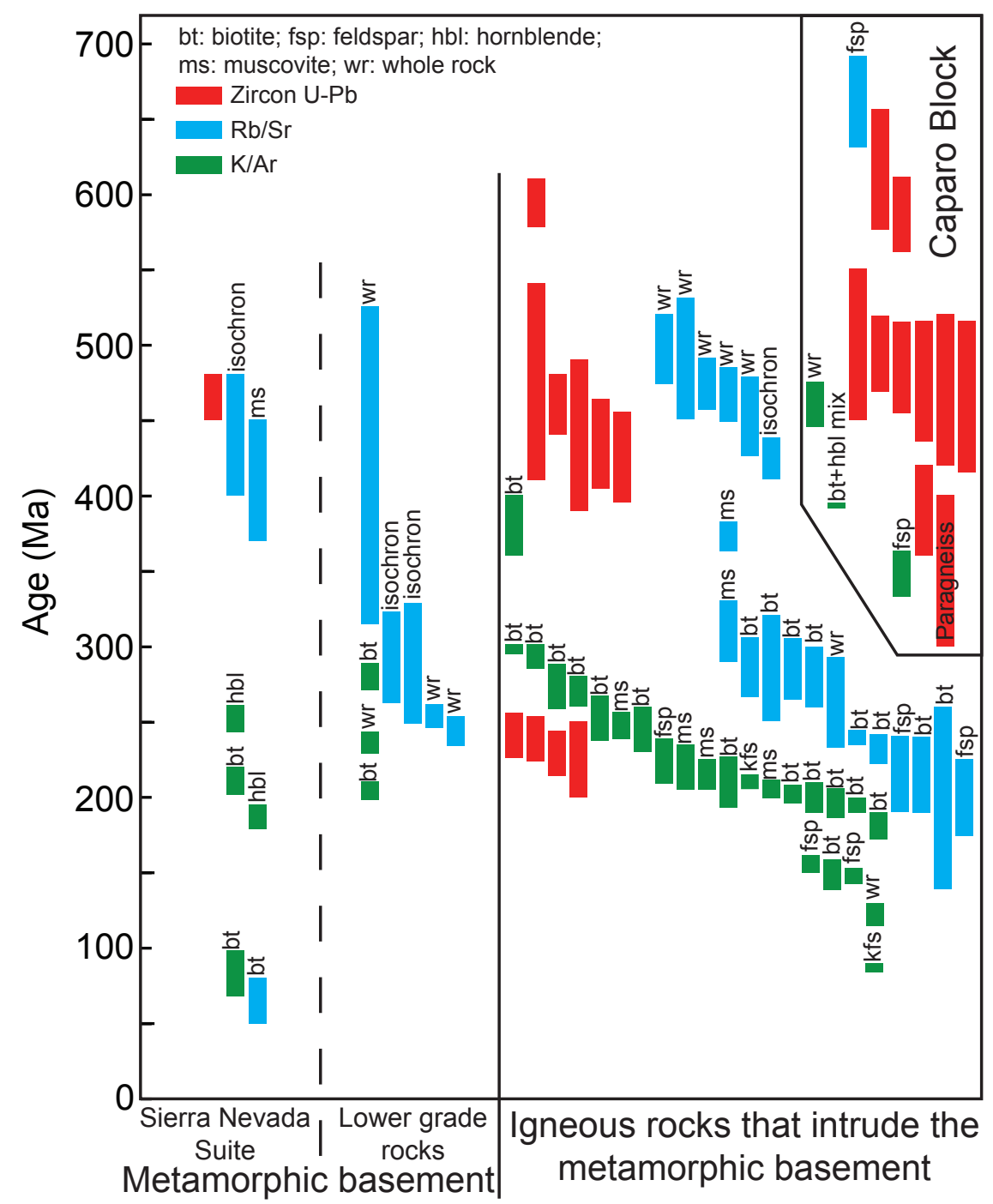




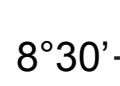

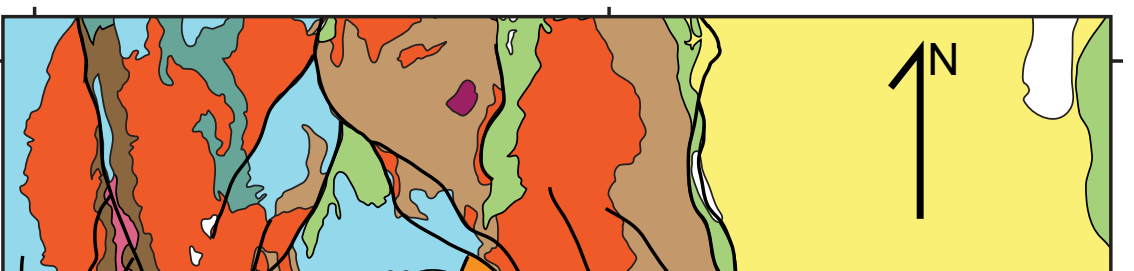

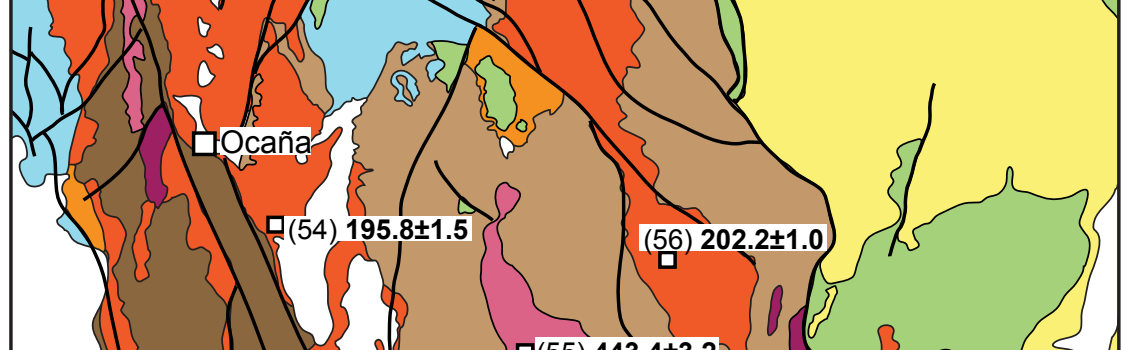

$8^{\circ}$

$6^{\circ} 30^{\prime}-$

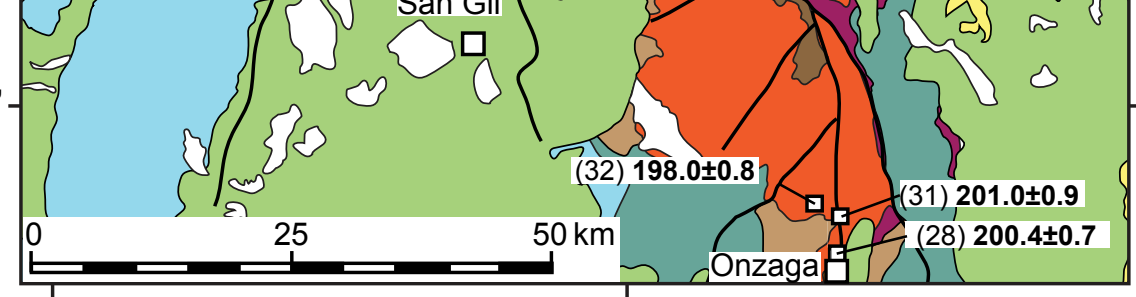

$(\mathrm{XX)} \mathrm{U}-\mathrm{Pb}$ (zircon) age $\pm \mathbf{2} \sigma$

Full sample codes 10VDLXX

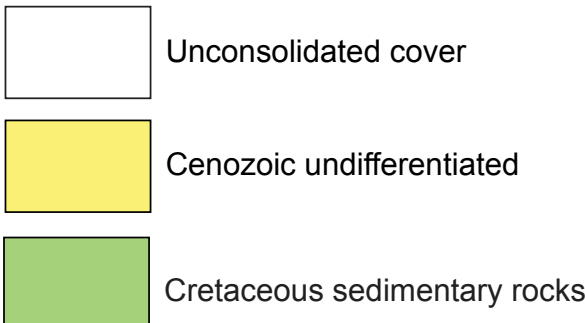
$\square$
Turassic sedimentary rocks
and Permian Bocas Fm.

Mesozoic volcanic rocks

Mesozoic granitoids

Santander Plutonic Group

Palaeozoic sedimentary rocks -

low degree metamorphism

Floresta and Diamante Fms.

Palaeozoic Granitoids

Palaeozoic - Berlin Orthogneiss

Precambrian to Palaeozoic -

Silgará Formation - phyllites, slates,

quartzites, and metasiltstones

Precambrian to Palaeozoic -

Bucaramanga Gneiss - pelitic to silicic

paragneisses, amphibolites and migmatites 


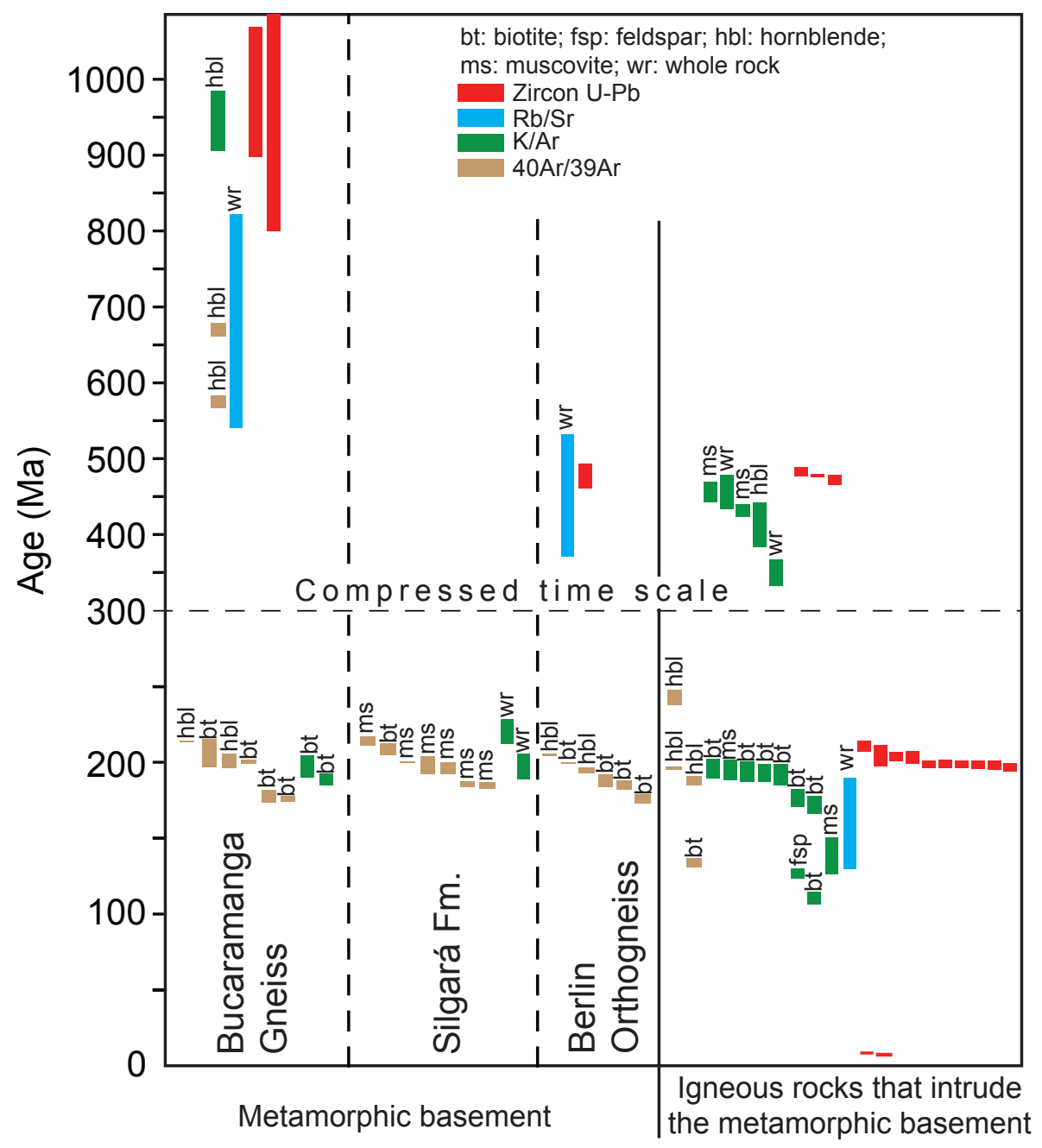




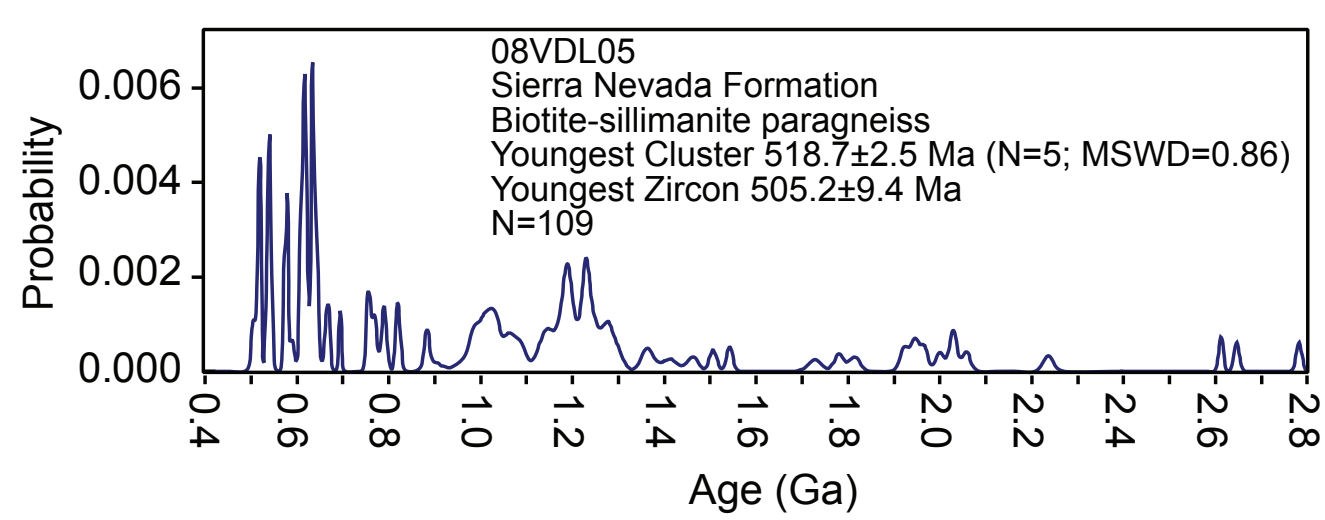




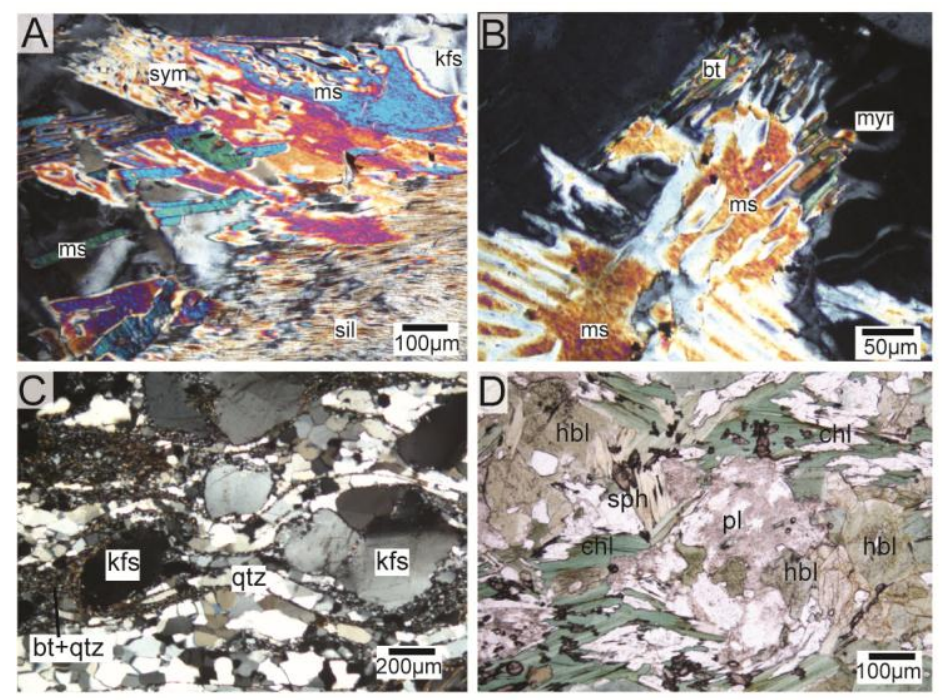




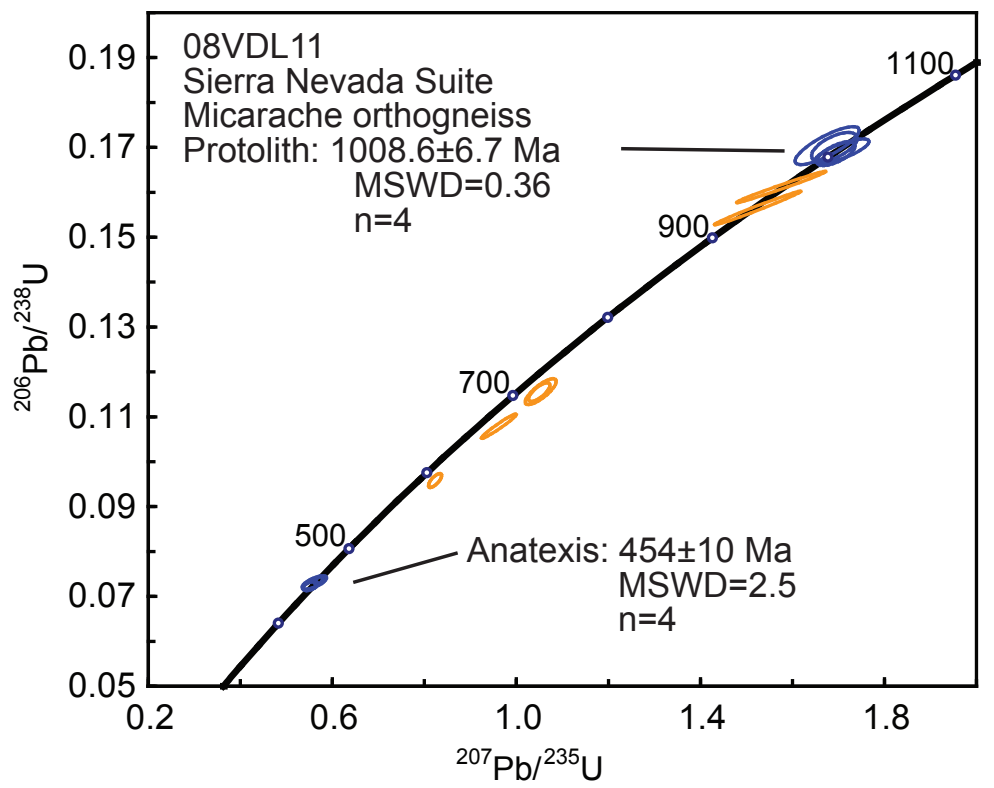




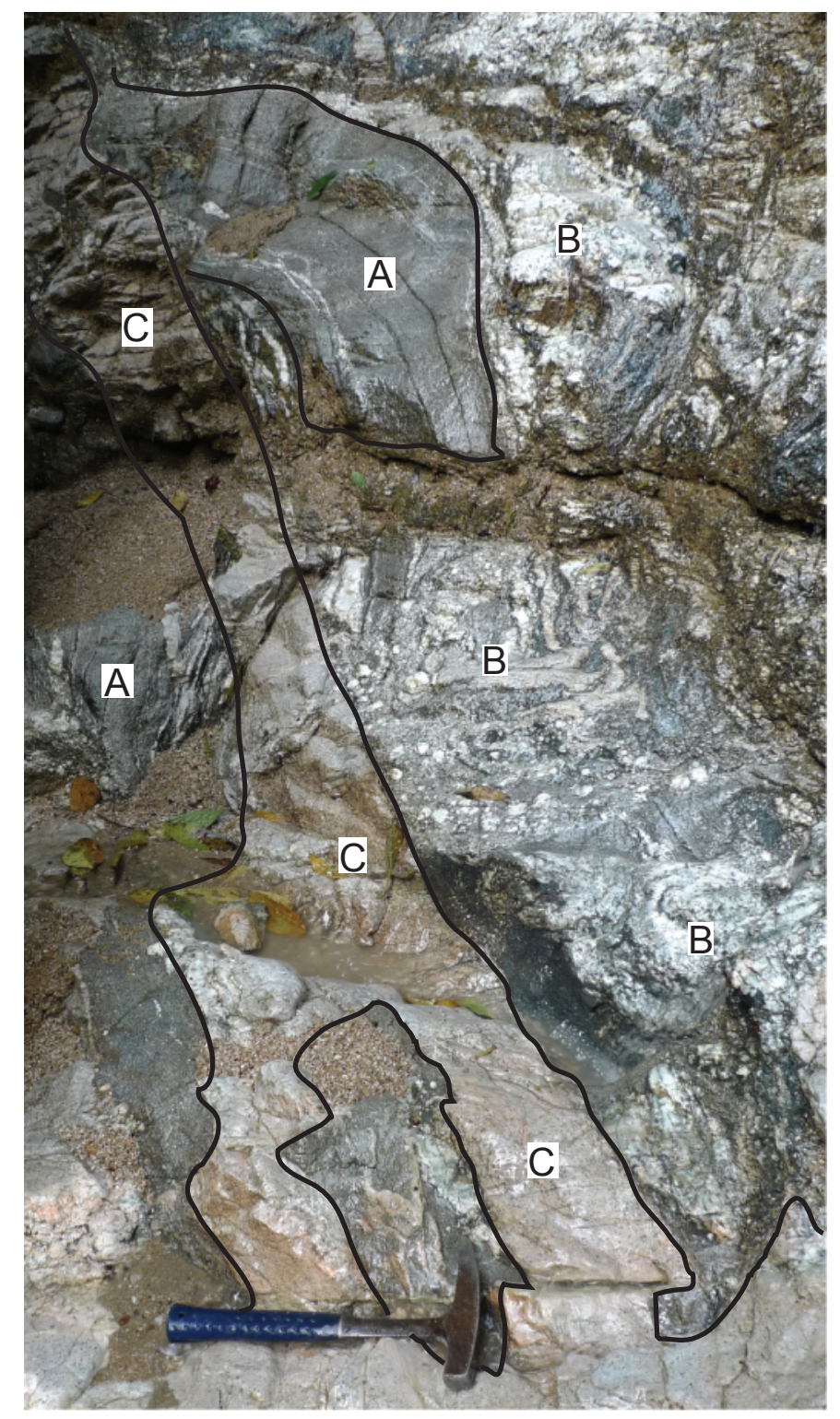



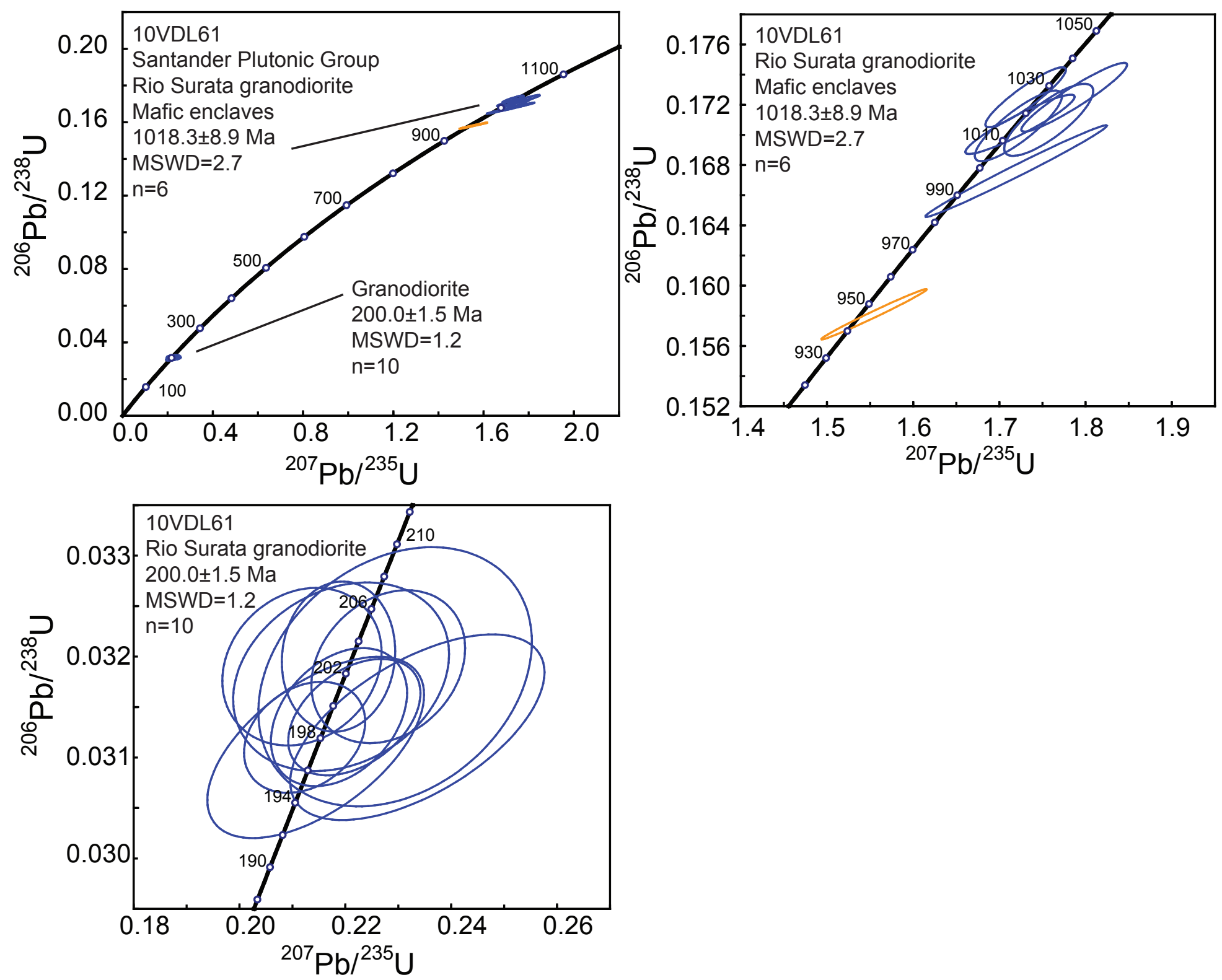

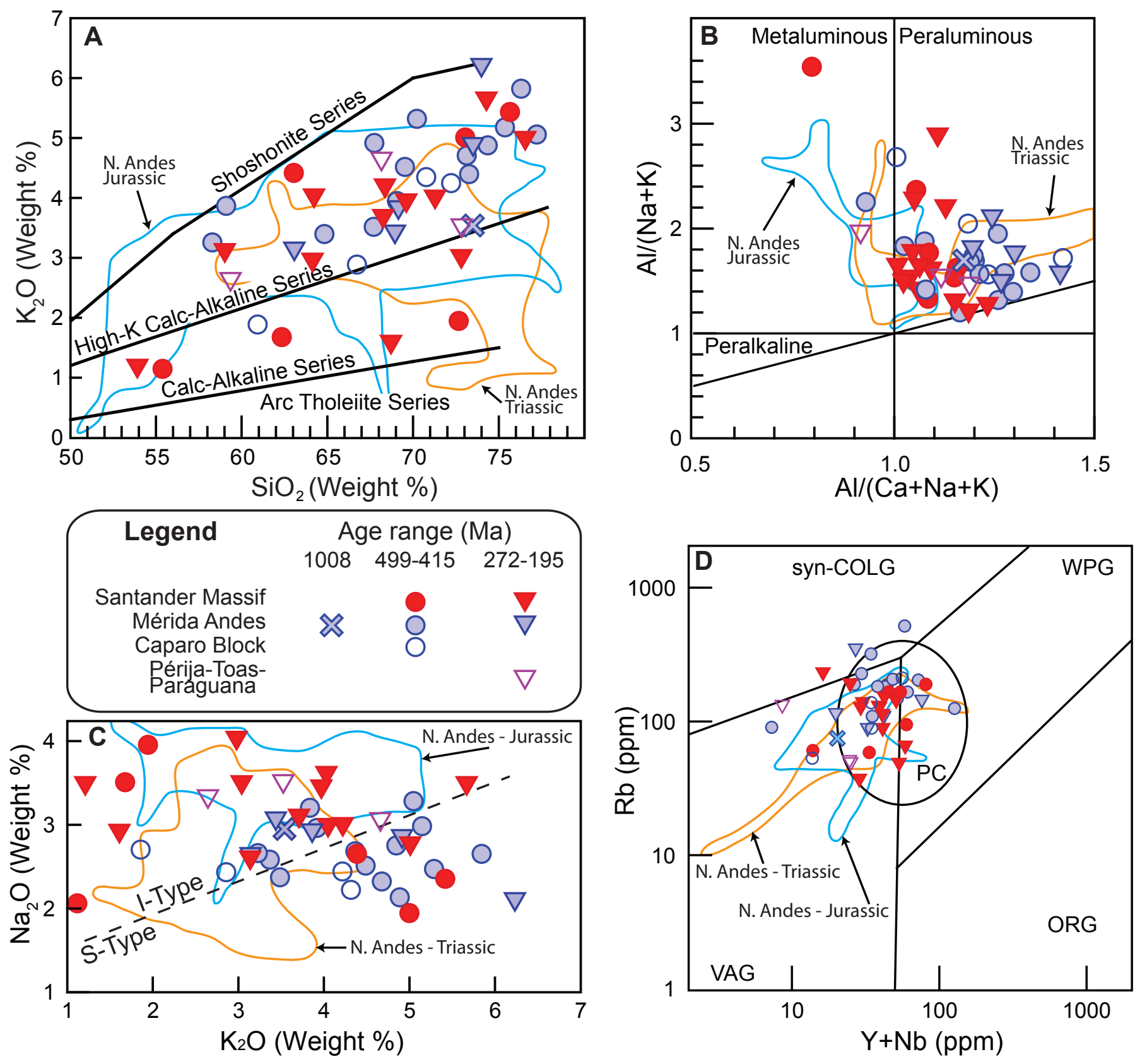

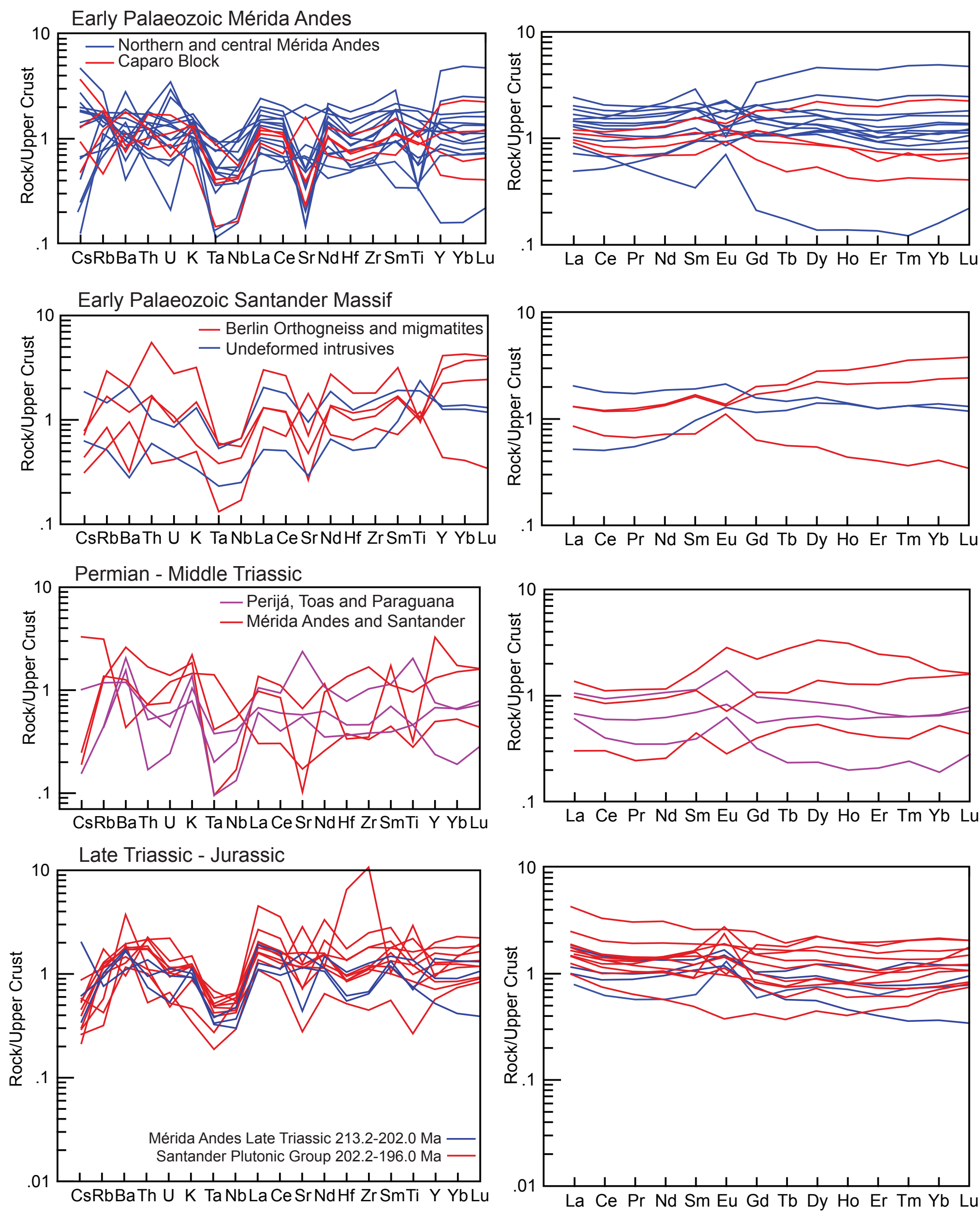


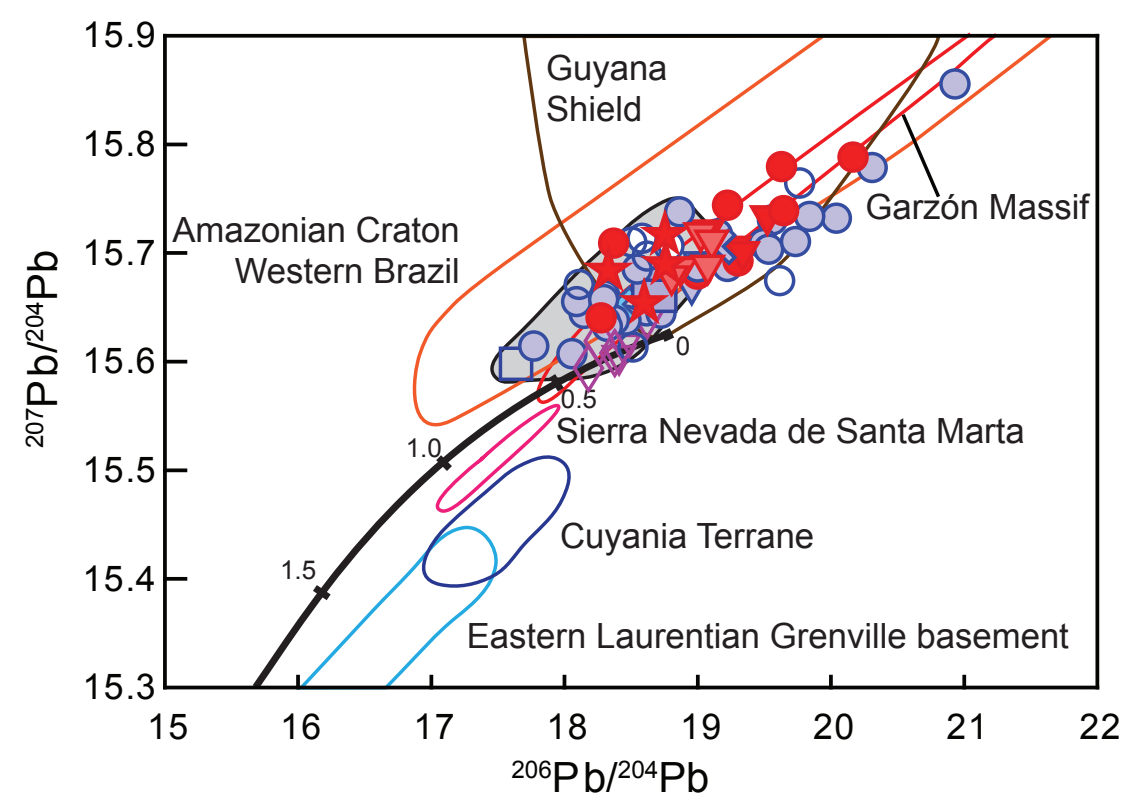




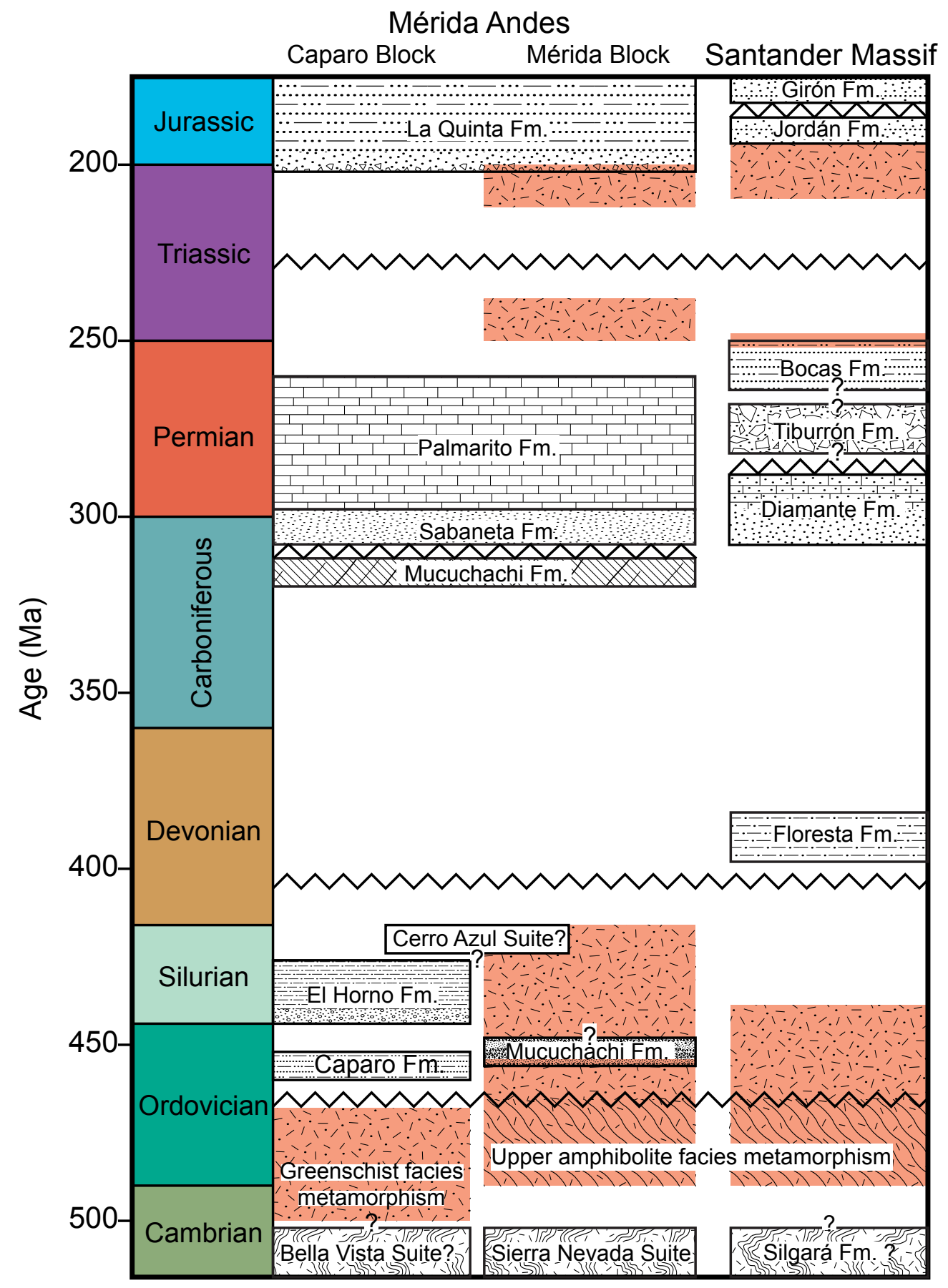


A) $~ 500-472 \mathrm{Ma}$

Compression and orogenesis

WNW
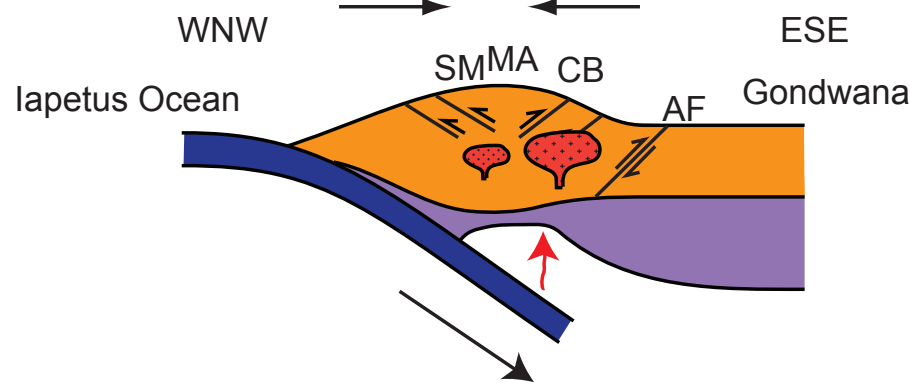

B) $\sim 472-452 \mathrm{Ma}$ Extension and basin formation

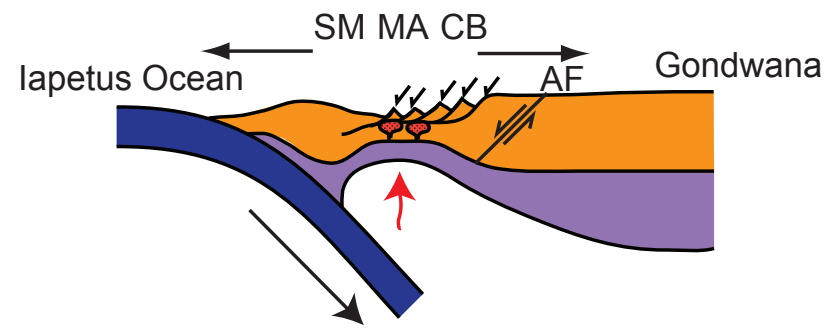

C) $\sim 450-440 \mathrm{Ma}$ Compression, sedimentary hiatuses

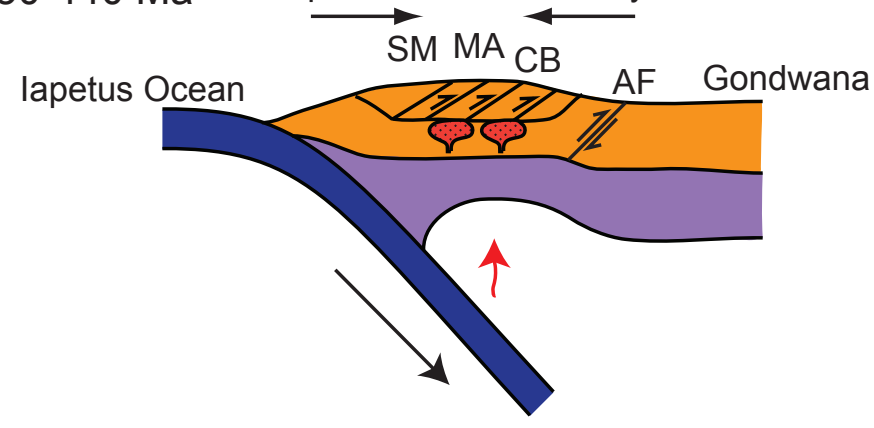




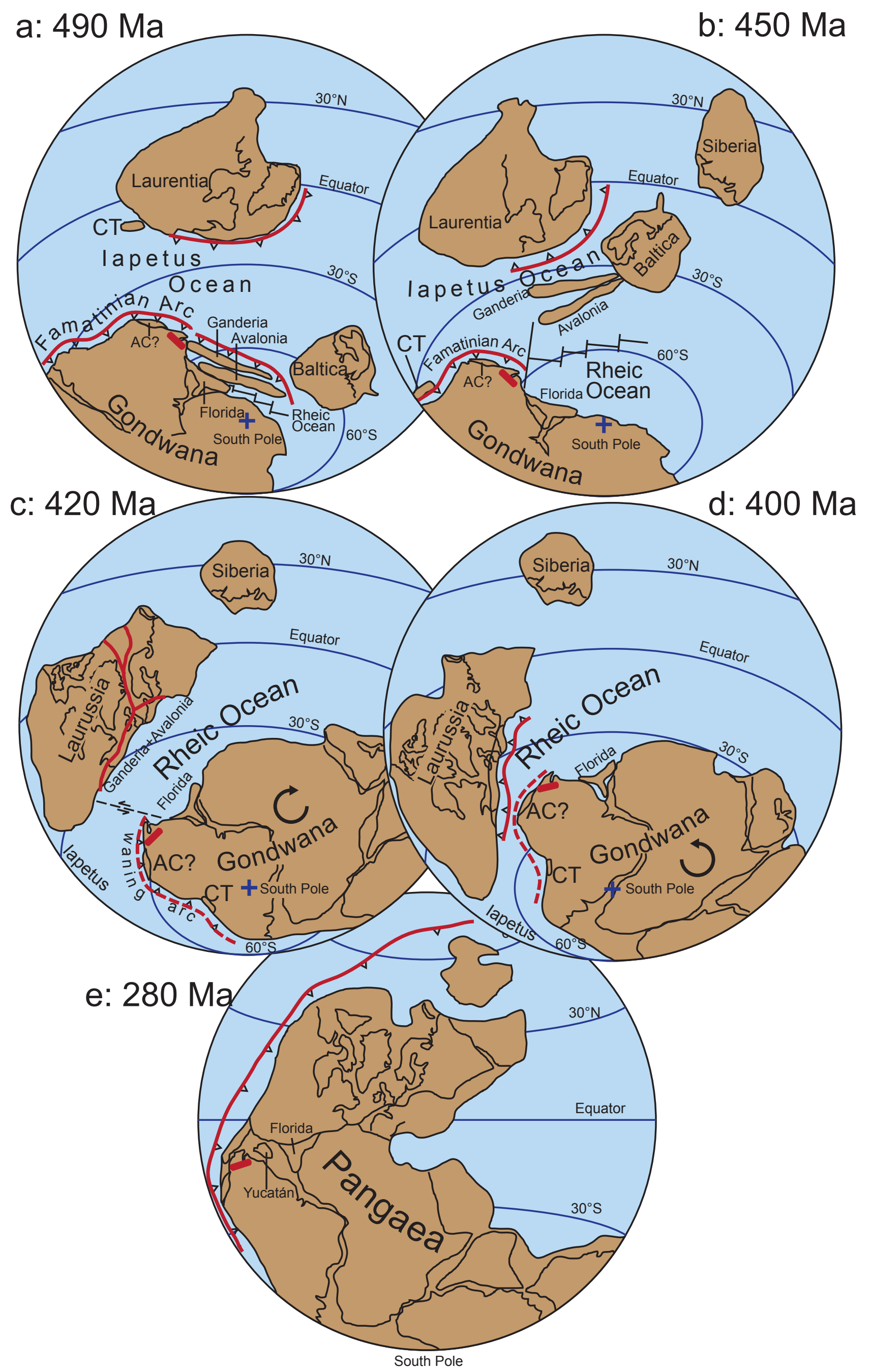



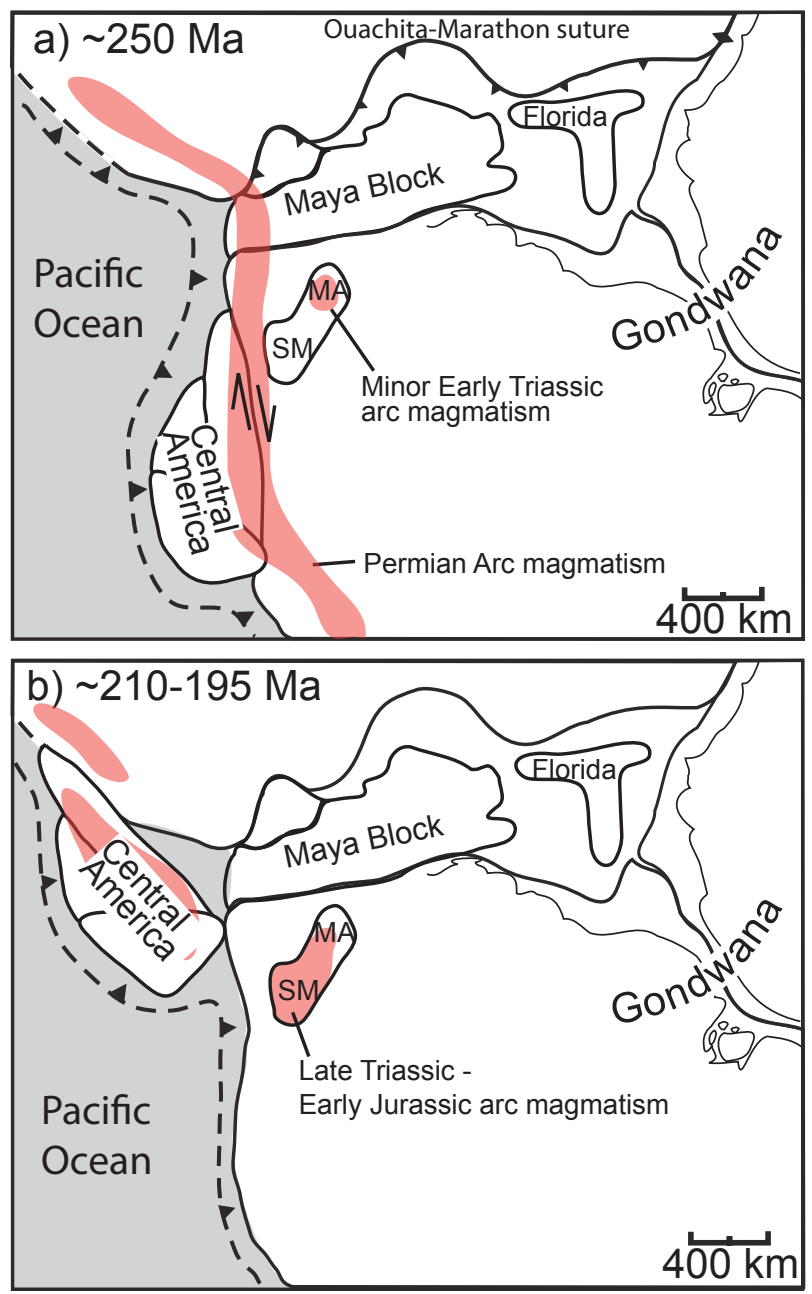
Table 1 - GPS coordinates and summary of geochronological data

\begin{tabular}{|c|c|c|c|c|c|c|c|c|c|c|}
\hline \multirow[b]{2}{*}{ Sample } & \multicolumn{2}{|c|}{ Sample Data } & \multicolumn{3}{|c|}{ GPS Coordinates } & \multicolumn{5}{|c|}{${ }^{206} \mathrm{~Pb} /{ }^{238} \mathrm{U}$ (zircon) data } \\
\hline & Location & Unit name & Latitude $\mathbf{N}$ & Longitude W & Alt (m) & Age \pm 2 & $2 \sigma(\mathrm{Ma})$ & MSWD & spots & $\mathrm{Th} / \mathrm{U}$ \\
\hline 08VDL03 & Mérida & Verdalito granodiorite & $8^{\circ} 28^{\prime} 49^{\prime \prime}$ & 71³4'13" & 363 & 449.3 & \pm 2.5 & 2.0 & 16 & 0.34 \\
\hline 08VDL04 & Mérida & Pueblo Hondo granite & $8^{\circ} 17^{\prime} 53^{\prime \prime}$ & $71^{\circ} 53^{\prime} 58^{\prime \prime}$ & 2010 & 434.2 & \pm 4.4 & 1.0 & 12 & 1.02 \\
\hline 08VDL05 & Mérida & Sierra Nevada paragneiss & $8^{\circ} 29^{\prime} 59^{\prime \prime}$ & $71^{\circ} 12^{\prime} 04^{\prime \prime}$ & 2247 & \multicolumn{4}{|c|}{$<505 \mathrm{Ma}$; detrital; see figure 6} & \\
\hline \multirow[t]{2}{*}{ 08VDL11 } & Mérida & Micarache Orthogneiss & $8^{\circ} 41^{\prime} 41^{\prime \prime}$ & $70^{\circ} 533^{\prime} 31 "$ & 3500 & 454.0 & \pm 10.0 & 2.5 & 3 & 0.97 \\
\hline & & 08VDL11, protolith & & & & 1008.6 & \pm 6.7 & 0.4 & 4 & 0.34 \\
\hline 08VDL14 & Mérida & El Carmen granodiorite & $8^{\circ} 45^{\prime} 07^{\prime \prime}$ & $70^{\circ} 57^{\prime} 33^{\prime \prime}$ & 3195 & 211.2 & \pm 1.2 & 2.3 & 14 & 0.40 \\
\hline 08VDL15 & Mérida & Bailadores alkali rhyolite & $8^{\circ} 11^{\prime} 51 "$ & $71^{\circ} 50^{\prime} 09^{\prime \prime}$ & 2058 & 452.6 & \pm 2.7 & 2.7 & 12 & 0.56 \\
\hline 08VDL18 & Mérida & La Quinta rhyodacite & $8^{\circ} 08^{\prime} 56^{\prime \prime}$ & $72^{\circ} 00^{\prime} 55^{\prime \prime}$ & 1138 & 202.0 & \pm 1.6 & 2.0 & 14 & 0.78 \\
\hline 08VDL21 & Mérida & La Grita Diorite & $8^{\circ} 08^{\prime} 28^{\prime \prime}$ & $71^{\circ} 56^{\prime} 15^{\prime \prime}$ & 2240 & 471.8 & \pm 4.0 & 2.0 & 13 & 0.91 \\
\hline 08VDL22 & Mérida & La Playita orthogneiss & 8०11'38" & $71^{\circ} 53^{\prime} 02^{\prime \prime}$ & 2489 & 449.7 & \pm 4.4 & 9.3 & 12 & 0.48 \\
\hline 08VDL23 & Mérida & Mucubaji granite & $8^{\circ} 48^{\prime} 36^{\prime \prime}$ & $70^{\circ} 48^{\prime} 47^{\prime \prime}$ & 3465 & 237.1 & \pm 1.4 & 3.8 & 12 & 0.12 \\
\hline 08VDL26 & Mérida & Mitisus striped gneiss & $8^{\circ} 52 ' 31 "$ & $70^{\circ} 37^{\prime} 48^{\prime \prime}$ & 1669 & 488.2 & \pm 4.3 & 2.0 & 6 & 0.36 \\
\hline 08VDL27 & Mérida & La Raya granitic gneiss & $8^{\circ} 51 ' 34 "$ & $70^{\circ} 34^{\prime} 51^{\prime \prime}$ & 1427 & 488.5 & \pm 6.5 & 2.0 & 11 & 0.38 \\
\hline 08VDL32 & Mérida & La Soledad granodiorite & $8^{\circ} 49^{\prime} 48^{\prime \prime}$ & $70^{\circ} 31^{\prime} 47^{\prime \prime}$ & 961 & 414.5 & \pm 3.9 & 5.6 & 14 & 0.36 \\
\hline 08VDL35 & Caparo & Cerro Azul granodiorite & $8^{\circ} 53^{\prime} 14 "$ & $70^{\circ} 23^{\prime} 34^{\prime \prime}$ & 848 & 499.4 & \pm 2.7 & 1.7 & 12 & 0.81 \\
\hline 08VDL36 & Mérida & Puente Real augen gneiss & $8^{\circ} 27^{\prime} 53^{\prime \prime}$ & $71^{\circ} 26^{\prime} 50^{\prime \prime}$ & 572 & 472.3 & \pm 3.4 & 4.1 & 14 & 0.59 \\
\hline 08VDL38 & Mérida & Macanas alkali granite & $8^{\circ} 20^{\prime} 19^{\prime \prime}$ & $71^{\circ} 37^{\prime} 21^{\prime \prime}$ & 1497 & 454.8 & \pm 4.2 & 1.5 & 11 & 0.60 \\
\hline 08VDL40 & Mérida & La Culata granodiorite & $8^{\circ} 48^{\prime} 27^{\prime \prime}$ & $71^{\circ} 00^{\prime} 04^{\prime \prime}$ & 4566 & 213.2 & \pm 1.7 & 3.0 & 15 & 0.32 \\
\hline 08VDL41 & Mérida & Chachopo granite & $8^{\circ} 55^{\prime} 55^{\prime \prime}$ & $70^{\circ} 47^{\prime} 31 "$ & 3119 & 454.5 & \pm 3.1 & 1.0 & 12 & 0.29 \\
\hline 08VDL44 & Mérida & Miraflores granodiorite & $9^{\circ} 10^{\prime} 42^{\prime \prime}$ & $70^{\circ} 38^{\prime} 08^{\prime \prime}$ & 867 & 466.8 & \pm 2.5 & 1.4 & 13 & 0.14 \\
\hline 08VDL45 & Mérida & Valera granodiorite & 9॰11'11" & $70^{\circ} 37^{\prime} 51 "$ & 838 & 447.9 & \pm 1.8 & 1.7 & 14 & 0.14 \\
\hline 08VDL46 & Mérida & La Quebrada granite & $9^{\circ} 10^{\prime} 25^{\prime \prime}$ & $70^{\circ} 32^{\prime 2} 24 "$ & 2358 & 243.5 & \pm 3.4 & 2.9 & 5 & 0.70 \\
\hline 08VDL47 & Mérida & Carmania monzodiorite & $9^{\circ} 15^{\prime} 59^{\prime \prime}$ & $70^{\circ} 38^{\prime} 18^{\prime \prime}$ & 789 & 450.4 & \pm 2.5 & 1.5 & 12 & 1.12 \\
\hline 08VDL49 & Mérida & La Puerta granodiorite & $9^{\circ} 07^{\prime} 11 "$ & $70^{\circ} 42^{\prime} 39 "$ & 1920 & 453.1 & \pm 1.8 & 2.1 & 14 & 0.16 \\
\hline 08VDL50 & Mérida & Timotes granite & $9^{\circ} 00^{\prime} 52^{\prime \prime}$ & $70^{\circ} 44^{\prime} 25^{\prime \prime}$ & 1931 & 445.2 & \pm 3.9 & 8.2 & 15 & 0.10 \\
\hline 08VDL55 & Caparo & Islitas tonalite & $7^{\circ} 49^{\prime} 01 "$ & $71^{\circ} 21^{\prime} 01^{\prime \prime}$ & 340 & 473.1 & \pm 3.5 & 2.0 & 16 & 0.60 \\
\hline 08VDL56 & Caparo & El Cambur granite & 752'29" & $71^{\circ} 16^{\prime} 03^{\prime \prime}$ & 303 & 492.3 & \pm 8.4 & 2.0 & 8 & 0.71 \\
\hline 08VDL57 & Caparo & El Tapo granite & 751'00" & $71^{\circ} 13^{\prime} 41^{\prime \prime}$ & 259 & 492.3 & \pm 5.3 & 4.8 & 8 & 0.52 \\
\hline 08VDL59 & Toas Isl. & Toas Island granodiorite & $10^{\circ} 57^{\prime 2} 23^{\prime \prime}$ & $71^{\circ} 37^{\prime} 45^{\prime \prime}$ & 1 & 248.9 & \pm 1.7 & 1.1 & 17 & 0.66 \\
\hline 08VDL60 & Perijá & Riecito del Palmar granite & $10^{\circ} 37^{\prime} 56^{\prime \prime}$ & $72^{\circ} 21 ' 26 "$ & 175 & 225.1 & \pm 1.5 & 1.1 & 16 & 0.90 \\
\hline 08VDL64 & Paraguaná & El Amparo diorite & $11^{\circ} 55^{\prime} 54^{\prime \prime}$ & $69^{\circ} 57^{\prime} 36^{\prime \prime}$ & 156 & 272.2 & \pm 2.6 & 2.3 & 13 & 0.61 \\
\hline 10VDL05 & Santander & Corcova granodiorite & $7^{\circ} 06^{\prime} 03^{\prime \prime}$ & $73^{\circ} 00^{\prime} 36^{\prime \prime}$ & 2793 & 198.3 & \pm 1.8 & 2.2 & 7 & 0.77 \\
\hline 10VDL22 & Santander & Pescadero granodiorite & $6^{\circ} 49^{\prime} 48^{\prime \prime}$ & $72^{\circ} 59^{\prime} 27^{\prime \prime}$ & 636 & 199.1 & \pm 1.3 & 2.5 & 15 & 0.88 \\
\hline 10VDL23 & Santander & Bucaramanga gneiss & $6^{\circ} 56^{\prime} 35^{\prime \prime}$ & $72^{\circ} 58^{\prime} 00^{\prime \prime}$ & 2055 & 461.0 & \pm 2.1 & 2.6 & 18 & 0.49 \\
\hline 10VDL28 & Santander & Onzaga granodiorite & 6²2'31" & $72^{\circ} 49^{\prime} 06^{\prime \prime}$ & 1876 & 200.4 & \pm 0.7 & 1.3 & 16 & 0.87 \\
\hline 10VDL31 & Santander & Onzaga granodiorite & 6०24'28" & $72^{\circ} 49^{\prime} 08^{\prime \prime}$ & 1800 & 201.0 & \pm 0.9 & 2.9 & 17 & 0.79 \\
\hline 10VDL32 & Santander & Mogotes granodiorite & 6²5'22" & $72^{\circ} 49^{\prime 29 "}$ & 1782 & 198.0 & \pm 0.8 & 1.3 & 17 & 0.81 \\
\hline 10VDL35 & Santander & Rio Surata Diorite & 7¹0'22" & $73^{\circ} 05^{\prime} 08^{\prime \prime}$ & 840 & 201.1 & \pm 1.4 & 1.9 & 12 & 1.17 \\
\hline 10VDL37 & Santander & Berlin orthogneiss & $7^{\circ} 11 ' 24 "$ & $72^{\circ} 58^{\prime} 41^{\prime \prime}$ & 1712 & 451.5 & \pm 1.3 & 1.0 & 13 & 0.38 \\
\hline 10VDL39 & Santander & Pegmatite from orthogneiss & $7^{\circ} 10^{\prime} 46 "$ & $72^{\circ} 59^{\prime} 48^{\prime \prime}$ & 1513 & 208.8 & \pm 1.2 & 2.2 & 12 & 0.03 \\
\hline \multirow[t]{2}{*}{ 10VDL43 } & Santander & Migmatite from orthogneiss & $7^{\circ} 14^{\prime} 18^{\prime \prime}$ & $72^{\circ} 49^{\prime} 30^{\prime \prime}$ & 3379 & 209.2 & \pm 3.4 & 6.0 & 5 & 0.02 \\
\hline & & 10VDL43, Host rock & & & & 460.3 & \pm 3.5 & 1.8 & 6 & 0.53 \\
\hline 10VDL44 & Santander & Berlin orthogneiss & $7^{\circ} 20^{\prime} 40^{\prime \prime}$ & $72^{\circ} 42^{\prime} 59^{\prime \prime}$ & 3023 & 473.5 & \pm 2.5 & 4.6 & 14 & 0.29 \\
\hline 10VDL46 & Santander & Pamplona granite & 7¹6'29" & $72^{\circ} 39^{\prime} 55^{\prime \prime}$ & 2458 & 439.2 & \pm 4.7 & 8.0 & 9 & 0.46 \\
\hline 10VDL47 & Santander & gabbrodiorite & 7²8'23" & $72^{\circ} 41^{\prime} 44^{\prime \prime}$ & 2615 & 483.7 & \pm 5.9 & 0.7 & 11 & 0.75 \\
\hline 10VDL49 & Santander & Silgará Fm. Gneiss & $7^{\circ} 29^{\prime} 20^{\prime \prime}$ & $72^{\circ} 42^{\prime} 16^{\prime \prime}$ & 2360 & 479.8 & \pm 3.1 & 1.7 & 17 & 0.20 \\
\hline 10VDL50 & Santander & Migmatite from paragneiss & $7^{\circ} 15^{\prime} 22 "$ & $72^{\circ} 53^{\prime} 45^{\prime \prime}$ & 3710 & 477.0 & \pm 5.3 & 7.5 & 9 & 0.82 \\
\hline 10VDL51 & Santander & Berlin orthogneiss & $7^{\circ} 15^{\prime} 17^{\prime \prime}$ & $72^{\circ} 53^{\prime} 48^{\prime \prime}$ & 3707 & 472.5 & \pm 3.4 & 11.5 & 17 & 0.30 \\
\hline 10VDL52 & Santander & Paramo Rico tonalite & $7^{\circ} 13^{\prime} 54 "$ & $72^{\circ} 53^{\prime} 54 "$ & 3731 & 199.8 & \pm 1.2 & 1.2 & 18 & 0.97 \\
\hline 10VDL54 & Santander & Ocana alkali granite & $8^{\circ} 09^{\prime} 45^{\prime \prime}$ & 73¹7'59" & 1268 & 195.8 & \pm 1.5 & 1.2 & 14 & 0.80 \\
\hline 10VDL55 & Santander & Tarra granodiorite & $8^{\circ} 03^{\prime} 10^{\prime \prime}$ & $73^{\circ} 04^{\prime} 31^{\prime \prime}$ & 1506 & 443.4 & \pm 3.2 & 3.8 & 12 & 0.45 \\
\hline 10VDL56 & Santander & Aguablanca granite & $8^{\circ} 07^{\prime} 08^{\prime \prime}$ & $72^{\circ} 56^{\prime} 51^{\prime \prime}$ & 1636 & 202.2 & \pm 1.0 & 2.3 & 16 & 0.79 \\
\hline 10VDL58 & Santander & Bocas Fm. Rhyolite & $7^{\circ} 26^{\prime} 27^{\prime \prime}$ & $73^{\circ} 13^{\prime 2} 24^{\prime \prime}$ & 569 & 250.7 & \pm 4.3 & 1.9 & 6 & 0.89 \\
\hline 10VDL59 & Santander & Rio Negro tonalite & $7^{\circ} 17^{\prime} 13^{\prime \prime}$ & $73^{\circ} 08^{\prime} 46^{\prime \prime}$ & 710 & 196.0 & \pm 1.1 & 1.5 & 14 & 1.29 \\
\hline \multirow[t]{2}{*}{ 10VDL61 } & Santander & Rio Surata granodiorite & $7^{\circ} 09^{\prime} 59^{\prime \prime}$ & $73^{\circ} 05^{\prime} 17^{\prime \prime}$ & 827 & 200.0 & \pm 1.5 & 1.2 & 10 & 1.13 \\
\hline & & 10VDL61, enclaves & & & & 1018.3 & \pm 8.9 & 2.7 & 6 & 0.31 \\
\hline
\end{tabular}




\begin{tabular}{|c|c|c|c|c|c|c|c|c|c|c|c|c|}
\hline 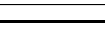 & 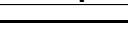 & 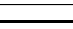 & 1 & & & & & & & & & \\
\hline \multicolumn{4}{|c|}{ Sample Data } & \multicolumn{3}{|c|}{ Concentration } & \multicolumn{3}{|c|}{ Present day isotopic ratios } & \multicolumn{3}{|c|}{ Initial isotopic ratios } \\
\hline Sample & Location & Age \pm 2 & $2 \sigma(\mathrm{Ma})$ & $\begin{array}{c}\mathrm{Pb} \\
(\mathrm{ppm})\end{array}$ & $\begin{array}{c}\text { Th } \\
\text { (ppm) }\end{array}$ & U (ppm) & ${ }^{206} \mathrm{~Pb} /{ }^{204} \mathrm{~Pb}$ & ${ }^{207} \mathrm{~Pb} /{ }^{204} \mathrm{~Pb}$ & ${ }^{208} \mathrm{~Pb} /{ }^{204} \mathrm{~Pb}$ & ${ }^{206} \mathrm{~Pb} /{ }^{204} \mathrm{~Pb}_{\mathrm{i}}$ & ${ }^{207} \mathrm{~Pb} /{ }^{204} \mathrm{~Pb}_{\mathrm{i}}$ & ${ }^{208} \mathrm{~Pb} /{ }^{204} \mathrm{~Pb}_{\mathrm{i}}$ \\
\hline 08VDL03 & Mérida & 449.3 & \pm 2.5 & 14.48 & 13.21 & 3.86 & 19.574 & 15.729 & 39.413 & 18.314 & 15.659 & 38.026 \\
\hline 08VDL04 & Mérida & 434.2 & \pm 4.4 & 16.91 & 5.61 & 0.59 & 18.628 & 15.645 & 38.566 & 18.475 & 15.636 & 38.091 \\
\hline 08VDL11 & Mérida & 454.0 & \pm 10.0 & 23.72 & 8.34 & 1.62 & 19.152 & 15.706 & 39.215 & 18.402 & 15.652 & 38.009 \\
\hline 08VDL14 & Mérida & 211.2 & \pm 1.2 & 17.48 & 10.26 & 3.17 & 19.021 & 15.691 & 39.104 & 18.630 & 15.671 & 38.691 \\
\hline 08VDL15 & Mérida & 452.6 & \pm 2.7 & 8.32 & 19.34 & 4.11 & 20.040 & 15.732 & 40.569 & 17.636 & 15.597 & 36.930 \\
\hline 08VDL21 & Mérida & 471.8 & \pm 4.0 & 16.91 & 11.58 & 2.32 & 18.737 & 15.643 & 38.793 & 18.069 & 15.605 & 37.722 \\
\hline 08VDL22 & Mérida & 449.7 & \pm 4.4 & 17.57 & 13.57 & 2.26 & 19.161 & 15.716 & 39.041 & 18.559 & 15.683 & 37.878 \\
\hline 08VDL27 & Mérida & 488.5 & \pm 6.5 & 24.44 & 23.43 & 9.57 & 20.944 & 15.854 & 39.712 & 18.877 & 15.736 & 38.088 \\
\hline 08VDL32 & Mérida & 414.5 & \pm 3.9 & 24.46 & 19.93 & 9.76 & 19.505 & 15.707 & 39.116 & 17.781 & 15.612 & 37.981 \\
\hline 08VDL38 & Mérida & 454.8 & \pm 4.2 & 17.58 & 18.28 & 3.94 & 19.221 & 15.702 & 39.074 & 18.159 & 15.642 & 37.488 \\
\hline 08VDL40 & Mérida & 213.2 & \pm 1.7 & 15.30 & 8.09 & 1.54 & 18.938 & 15.671 & 39.005 & 18.720 & 15.660 & 38.631 \\
\hline 08VDL41 & Mérida & 454.5 & \pm 3.1 & 17.87 & 11.41 & 8.25 & 20.322 & 15.777 & 39.024 & 18.103 & 15.653 & 38.037 \\
\hline 08VDL44 & Mérida & 466.8 & \pm 2.5 & 15.60 & 15.26 & 3.67 & 19.545 & 15.702 & 39.704 & 18.387 & 15.636 & 38.154 \\
\hline 08VDL45 & Mérida & 447.9 & \pm 1.8 & 25.23 & 13.46 & 2.71 & 18.803 & 15.683 & 38.902 & 18.306 & 15.655 & 38.108 \\
\hline 08VDL47 & Mérida & 450.4 & \pm 2.5 & 14.02 & 15.03 & 2.73 & 19.235 & 15.686 & 39.376 & 18.319 & 15.635 & 37.753 \\
\hline 08VDL49 & Mérida & 453.1 & \pm 1.8 & 17.96 & 10.86 & 3.17 & 19.851 & 15.732 & 38.789 & 19.014 & 15.685 & 37.867 \\
\hline 08VDL50 & Mérida & 445.2 & \pm 3.9 & 22.92 & 9.30 & 6.97 & 19.746 & 15.709 & 38.673 & 18.335 & 15.630 & 38.067 \\
\hline 08VDL35 & Caparo & 499.4 & \pm 2.7 & 115.74 & 7.01 & 1.75 & 18.595 & 15.712 & 38.736 & 18.517 & 15.708 & 38.636 \\
\hline 08VDL55 & Caparo & 473.1 & \pm 3.5 & 11.07 & 8.57 & 2.46 & 19.628 & 15.673 & 39.057 & 18.527 & 15.611 & 37.824 \\
\hline 08VDL56 & Caparo & 492.3 & \pm 8.4 & 59.63 & 13.47 & 1.90 & 18.797 & 15.705 & 38.932 & 18.634 & 15.695 & 38.562 \\
\hline 08VDL57 & Caparo & 492.3 & \pm 5.3 & 14.93 & 18.36 & 4.72 & 19.779 & 15.763 & 39.985 & 18.123 & 15.669 & 37.916 \\
\hline 08VDL59 & Toas Island & 248.9 & \pm 1.7 & 42.84 & 6.85 & 1.23 & 18.450 & 15.611 & 38.013 & 18.378 & 15.607 & 37.884 \\
\hline 08VDL60 & Perijá & 225.1 & \pm 1.5 & 6.67 & 1.81 & 0.68 & 18.408 & 15.604 & 37.937 & 18.180 & 15.593 & 37.739 \\
\hline 08VDL64 & Paraguaná & 272.2 & \pm 2.6 & 8.97 & 5.53 & 1.66 & 18.617 & 15.637 & 38.443 & 18.262 & 15.618 & 37.893 \\
\hline 10VDL05 & Santander & 198.3 & \pm 1.8 & 15.86 & 22.66 & 3.12 & 19.272 & 15.706 & 39.543 & 18.871 & 15.686 & 38.593 \\
\hline 10VDL22 & Santander & 199.1 & \pm 1.3 & 12.01 & 19.66 & 2.65 & 19.256 & 15.700 & 39.520 & 18.805 & 15.678 & 38.428 \\
\hline 10VDL23 & Santander & 461.0 & \pm 2.1 & 11.99 & 6.80 & 2.36 & 19.381 & 15.676 & 39.020 & 18.435 & 15.623 & 38.143 \\
\hline 10VDL37 & Santander & 451.5 & \pm 1.3 & 7.73 & 4.08 & 1.17 & 19.310 & 15.693 & 38.891 & 18.599 & 15.653 & 38.093 \\
\hline 10VDL39 & Santander & 208.8 & \pm 1.2 & 49.35 & 0.34 & 1.15 & 19.074 & 15.721 & 39.034 & 19.024 & 15.718 & 39.029 \\
\hline 10VDL43 & Santander & 209.2 & \pm 3.4 & 12.56 & 5.24 & 1.08 & 19.523 & 15.734 & 39.414 & 19.107 & 15.711 & 38.765 \\
\hline 10VDL44 & Santander & 473.5 & \pm 2.5 & 27.50 & 18.33 & 2.64 & 19.232 & 15.743 & 39.631 & 18.754 & 15.716 & 38.565 \\
\hline 10VDL47 & Santander & 483.7 & \pm 5.9 & 5.06 & 6.37 & 1.24 & 19.642 & 15.778 & 39.976 & 18.382 & 15.707 & 37.896 \\
\hline 10VDL50 & Santander & 477.0 & \pm 5.3 & 22.48 & 29.88 & 3.93 & 19.639 & 15.738 & 40.245 & 18.760 & 15.689 & 38.096 \\
\hline 10VDL51 & Santander & 472.5 & \pm 3.4 & 8.37 & 17.53 & 3.02 & 20.170 & 15.787 & 40.671 & 18.329 & 15.683 & 37.237 \\
\hline 10VDL55 & Santander & 443.4 & \pm 3.2 & 15.19 & 10.91 & 2.39 & 19.010 & 15.679 & 38.885 & 18.288 & 15.638 & 37.824 \\
\hline 10VDL61 & Santander & 200.0 & \pm 1.5 & 11.93 & 10.88 & 1.51 & 19.337 & 15.701 & 39.504 & 19.076 & 15.688 & 38.892 \\
\hline
\end{tabular}




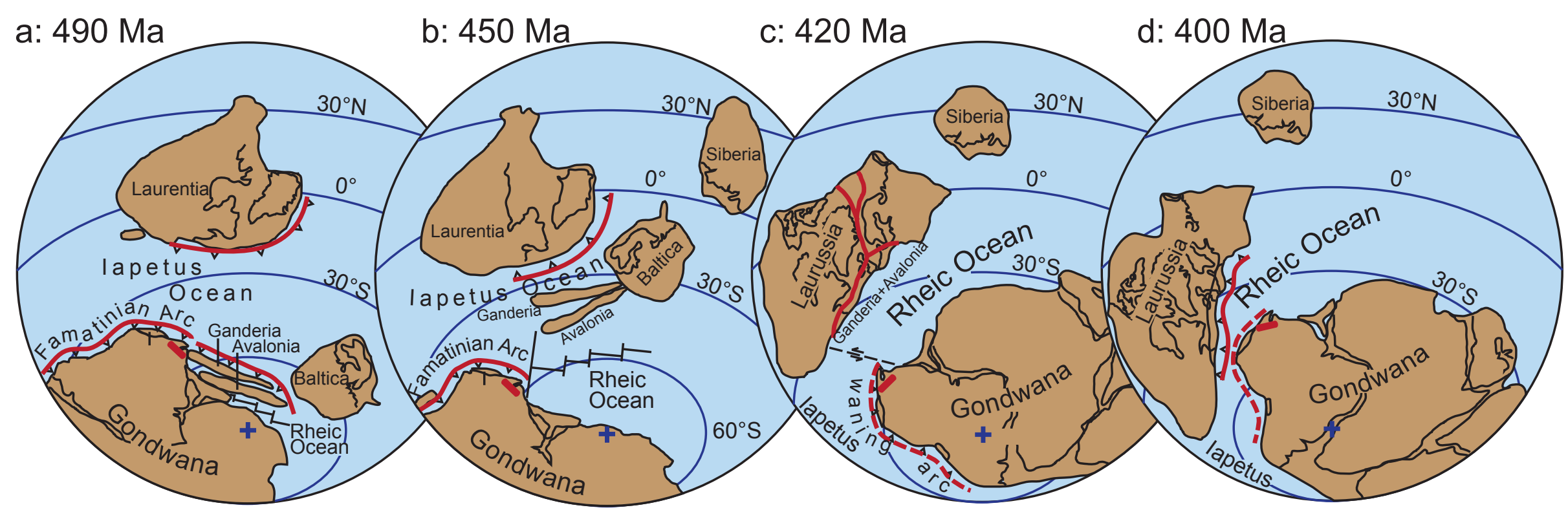

